\title{
Corporate Tax Policy and the Right to Know: Improving State Tax Policymaking by Enhancing the Legislative and Public Access
}

Richard Pomp

University of Connecticut School of Law

Follow this and additional works at: https://opencommons.uconn.edu/law_papers

Part of the Taxation-Federal Commons, Taxation-State and Local Commons, and the Tax Law Commons

\section{Recommended Citation}

Pomp, Richard, "Corporate Tax Policy and the Right to Know: Improving State Tax Policymaking by Enhancing the Legislative and Public Access" (1993). Faculty Articles and Papers. 574.

https://opencommons.uconn.edu/law_papers/574 


\title{
CORPORATE TAX POLICY AND THE RIGHT TO KNOW
}

\author{
Improving State Tax Policymaking \\ By Enhancing Legislative and Public Access
}

By

Professor Richard D. Pomp

Alva P. Loiselle Professor of Law

School of Law

University of Connecticut

for

The Fiscal Policy Institute

146 State Street

Albany, New York 12207

December 1993 


\section{CONTENTS}

Executive Summary $\quad$ i

$\begin{array}{ll}\text { I. Introduction } & 1\end{array}$

II. The Disclosure of Income Tax Information at the 4

Federal Level: An Historical Perspective

A. The Civil War Income Taxes: 1861-1872 5

B. The 1894 Income Tax $\quad 7$

C. The Tariff Act of $1909 \quad 8$

D. 1913 - $1923 \quad 10$

E. The 1924 and 1926 Acts 11

F. The Pink Slip Provisions: 1934 - 1935

G. SEC Disclosure: 1933 - Present 20

H. Citizens for Tax Justice and the Use of SEC-Required
Disclosure for Tax Policy Analysis

I. Summary 24

III. Disclosure at the State Level 26

A. Massachusetts 26

B. West Virginia 28

C. Arkansas 29

D. Wisconsin 31

E. Lessons to Date 32

IV. Evaluating the Case for State-Level Tax Disclosure by
Publicly-Traded Corporations

A. Firm-Specific Disclosure is Necessary for
Informed Tax Policy

B. Firm-Specific Disclosure is Essential to Public
Understanding of Corporate Tax Issues

C. Sunlight is the Best Disinfectant: Disclosure

Would Promote Openness and Accountability 39

D. State-Level Disclosure Will Complement SECMandated Disclosure $\quad 40$

E. Why Not Disclose Firm-Specific Data Anonymously? 41

F. Will Disclosure Violate a Corporation's Right to Privacy? 43

G. Will Disclosure Reveal Proprietary Information? 43

H. Will Disclosure Discourage the Filing of Accurate Tax Returns?

I. Will Disclosure Undercut a State's 48 "Business Climate"?

J. Conclusion 50

V. Formulating State Disclosure Policy 51

A. Who Should be Covered by Disclosure? 51

B. What Information Should be Disclosed? 53

1. Tax Expenditures 53

2. Normative Provisions 54

C. The Mechanics of Disclosure 57

$\begin{array}{ll}\text { VI. Conclusion } & 61\end{array}$

$\begin{array}{ll}\text { Endnotes } & 63\end{array}$ 


\title{
CORPORATE TAX POLICY AND THE RIGHT TO KNOW \\ Improving State Tax Policymaking By Enhancing Legislative and Public Access
}

\author{
Executive Summary
}

\begin{abstract}
During the 1980's, Citizens for Tax Justice (CTJ), a Washington-based think tank, was able to utilize data from annual reports to shareholders and to the Securities and Exchange Commission (SEC) to document that some of the largest, most profitable corporations in the country were paying little or nothing in federal income taxes. The public outcry that resulted from the reporting of this information was one of the keys to the sweeping changes included in the Tax Reform Act of 1986.
\end{abstract}

\section{State-Level Disclosure}

CTJ's work cannot be replicated at the state level. The annual reports of publicly-traded corporations contain information on the aggregate amount of state and local income taxes paid, but this information is not broken down state-by-state. And, until recently, only Wisconsin allowed the public to obtain information on the amount of state income tax paid by specific corporations.

The effective use of the information disclosed pursuant to the SEC requirements motivated state legislators and tax reformers to consider statelevel disclosure laws. Their interest was heightened by the revenue shortfalls that state and local governments were facing as a result of reductions in federal aid, unfunded federal mandates, the recession, and overly ambitious state tax reductions. In addition, many states adopted a variety of new corporate tax incentives in an effort to stimulate their recession-plagued economies. At the same time, some of those states and others labor under constitutional or statutory limitations on revenue-raising at the local or state levels.

In light of the states' budget problems, questions were raised about whether corporations were paying their "fair share" of the cost of public services. And, specifically, the adoption of new corporate tax incentives in the face of looming deficits raised serious concerns about whether these provisions were achieving their intended goals. It soon became obvious that none of these questions could be answered without more information about the state corporate income taxes being paid by specific, large businesses and the amount of state tax incentives they were receiving.

Corporations pay over $\$ 20$ billion yearly in state corporate income taxes, but the lack of state disclosure makes it impossible to evaluate the extent to which the corporate tax burden is allocated fairly or rationally in relationship to measures of profitability. In addition, while 
businesses receive billions annually in state tax incentives it is not known which corporations receive what types of incentives and in what amounts. Hence it is not possible to analyze accurately the effectiveness of the billions of dollars being expended annually through state tax incentives.

The issue of state corporate tax disclosure was raised in 1987 by a staff study for New York State's Legislative Tax Study Commission, and since then three states (Arkansas, West Virginia, and Massachusetts) have adopted laws providing for some state-level disclosure by corporate name. While Wisconsin has had a disclosure law since 1923, it has only recently been used for tax policy purposes. In 1991, the Wisconsin Action Coalition used the information available under that law to compile a list of major corporations doing business in the state that had paid only nominal state income taxes. This contributed to legislative adoption, on two occasions, of a new corporate minimum tax, which, in both cases, was vetoed by the Governor.

In 1991, both Arkansas and West Virginia adopted statutes providing for the disclosure of information on the dollar amount of certain specific credits taken by corporate and individual taxpayers. The Arkansas law is a Freedom of Information Act -type statute, and allows interested parties to request from the Arkansas Director of Taxation, by name of taxpayer, the amount of benefits received pursuant to specified business tax incentives and any additional incentives of the same type enacted after January 1, 1991.
The West Virginia statute has more of a tax policy orientation. It requires the state's Tax Commissioner to publish an annual report indicating the name and address of every taxpayer, whether a corporation or individual, receiving any one of 12 specific credits, and the amount, by broad dollar category, of the credit received.

Support for disclosure legislation in West Virginia arose after a state government report showed that only a small number of taxpayers benefit from the state's so-called supercredit, with about 50 firms claiming credits in excess of $\$ 100,000$ annually. This credit was estimated to cost the state $\$ 60$ million in forgone revenue in FY 1991 when its corporate income tax was yielding less than $\$ 200$ million. The first report under the West Virginia Law is scheduled to be issued in December, 1993.

The most comprehensive of the new laws was enacted in 1993 in Massachusetts as the result of the efforts of a state-level tax reform organization, the Tax Equity Alliance for Massachusetts (TEAM). Originally put forward as a state ballot question, the new Massachusetts law was written as part of an agreement among TEAM, the business community, and legislative leaders. This statute requires all publicly-traded corporations that do business in the state, and which already publish, in SEC-required reports, their federal income tax liability and their aggregate state income tax liability, to disclose six key items of information related to their Massachusetts taxable income and tax liability. The information to be disclosed will be 
sufficient to allow for a fair evaluation of the workings of the state's corporate income tax. The law established similar requirements for banks and insurance companies. The first public filings under this statute are due at the Massachusetts Secretary of State's office by December 31, 1993.

\section{Disclosure at the Federal Level}

Some observers of these recent developments have seen them as innovative, if not radical. In reality, extensive financial information, including tax information, is already in the public domain because of SEC regulations and generally accepted accounting principles (GAAP). What is not fully appreciated, however, is that prior to the enactment of the Securities Act of 1933 and the Securities Exchange Act of 1934, corporate tax returns or key items of tax information were frequently matters of public record.

A review of the history of public access to federal tax returns reveals that the issue of corporate tax disclosure was almost always intertwined with questions related to the privacy of individual tax returns. The privacy extended to federal corporate returns generally piggybacked onto the treatment of individual returns. The privacy issue was basically fought--and lost--over the issue of whether individual returns should be public information. However, no one on either side of the debate went to great lengths to distinguish the different issues involved in corporate disclosure from those of access to individual returns. Having chosen to pitch their battle over access to individual returns, supporters of disclosure gave up an opportunity to achieve corporate disclosure directly through the provisions of the Internal Revenue Code.

The few times when Congress did focus on the differences between corporations and individuals, it tended to opt for more disclosure in the case of corporations. Even today, the fact that a $1 \%$ shareholder can inspect the tax return of his or her corporation (although the shareholder cannot disclose any information obtained from the inspection), indicates a willingness to recognize less legitimate claims to privacy in the case of corporations than in the case of individuals.

In recent years, the need for public access to federal corporate income tax returns has been mooted. The SEC has essentially preempted the issue by mandating the disclosure by publiclytraded corporations of extensive financial data including numerous components of tax expense, including specifically information on investment tax credits.

\section{The Case for State Level Disclosure}

The debate has now shifted to whether the public should have access to state tax data by name of corporation. This debate has been fueled by revelations that large numbers of profitable corporations were paying little or nothing in state income taxes. For example, until New York's major corporate tax reform in the late 1980s, many of that state's largest and most profitable corporations -- some having 
New York sales in excess of $\$ 1$ billion and New York property in excess of \$2 billion -- only paid the state's nominal minimum tax of $\$ 250$. These statistics have led to efforts to learn more about the workings of state corporate income taxes, but these attempts have been stymied by the inability to correlate data with specific corporations.

Summarized below are the key arguments for state-level disclosure and discussions of some of the major questions that have been raised regarding the disclosure of corporate tax information at the state level.

\section{Firm-Specific Disclosure is Necessary for Informed Tax Policy}

The public has an obvious interest in a state's corporate income tax, if for no other reason that huge sums of money are involved both in the amount of corporate taxes imposed (over $\$ 20$ billion annually) and the amount forgiven through tax incentives.

The issue of how a state taxes, or exempts from tax, corporate activity raises fundamental value judgments about how the costs of government should be distributed. Both large-scale corporate tax avoidance and inefficient tax expenditures mean that a state must rely more heavily on other taxes -- with different incidence patterns -- or cut spending.

Another significant issue is how the corporate tax is distributed among corporations and among industries within states. Existing state corporate taxes are replete with provisions that discriminate between small and large corporations, in-state corporations and out-of-state corporations, capitalintensive corporations and laborintensive corporations, and corporations that sell out-of-state and those that sell within the state. The level playing field is still a fantasy in most states.

\section{Firm-Specific Disclosure is Essential to Public Understanding of Corporate Tax Reform Issues}

Public understanding of seemingly complex issues has been essential to the development and implementation of the many important economic reforms instituted at the federal and state levels during the twentieth century. Government officials are unlikely to be able to enact economic reform legislation, even if it is based on sound theoretical reasoning and extensive empirical evidence, if they are unable to explain the need for such laws to the ordinary citizen; nor, in our democratic society, should they be able to do so. Specific case studies are essential to explaining complex economic issues to the public, as CTJ's experience in the 1980 's demonstrated.

Opponents of disclosure contend that the general public is unable to understand the significance and implications of corporate tax information. Only tax experts, it is held, can understand the multifarious and complex factors that interact to generate a corporation's tax liability. The public would merely be confused, or unreasonably angered, by learning of nominal corporate tax liabilities. The "ignorant public" argument ultimately challenges the premises underlying a 
democratic society. A well-functioning democracy requires an informed public. If corporations feel that the disclosed information is likely to be misinterpreted, they can educate the public by providing more information and a fuller explanation.

\section{Sunlight is the Best Disinfectant: Disclosure Would Promote Openness and Accountability}

To evaluate whether tax incentives serve their ostensible purposes, the public must know, at the least, which corporations received what types of incentives and in what amounts. Only then can the public and the state legislatures judge whether the benefits of these incentives justify the forgone revenue, whether the benefits are equitably distributed among the corporate community, and whether such incentives need to be enhanced, reduced, or redirected. It can thus restore public confidence in both the corporate sector and government tax policy by either showing that the current system is working well or by providing the information necessary for effective reform.

\section{State-Level Disclosure will Complement SEC-Mandated Disclosure}

Compared with the extensive information already in the public domain because of SEC requirements, state disclosure is modest. Primarily because of the SEC, the public has been given a window into the financial affairs, including the income tax data of publicly-traded corporations. State disclosure would open that window a crack more.

State tax disclosure will also allow securities analysts to more effectively consider the impact of non-recurring items of income or expense on a corporation's earnings potential. Although the SEC-required disclosure is sufficient to adjust for the federal consequences of the item involved, it will in many cases not be sufficient to make the necessary change in the state tax results of the item.

\section{Why Not Disclose Firm-Specific Data Anonymously?}

Unless the name of a taxpayer is published along with its corporate tax information, it would be nearly impossible to obtain the benefits intended by disclosure. Corporations whose tax liabilities appear unconscionably low cannot be identified from statistical aggregates. Tax policy judgments cannot be made in the abstract but need an identifiable context in which to operate.

The disclosure of firm-specific data without corporate names would make it impossible to do inter-industry or intraindustry comparisons. It would also make it impossible to match the disclosed tax information with other publicly available data on employment, investment, and other relevant factors. And, if the same code number was not assigned to a firm every year, it would not be possible to do even limited longitudinal analyses.

Will Disclosure Violate a Corporation's Right to Privacy? 
The extent of SEC-required disclosure by registered corporations makes it obvious that such corporations have long ago surrendered any claim that their financial data should be protected under some right of privacy. If the disclosure of their federal income tax liabilities and other financial information does not raise a constitutional issue, then neither should the disclosure of their state tax information.

Revealing the taxes paid by small, closely-held, corporations might be viewed as violating legitimate expectations of privacy by its shareholders. Accordingly, such corporations could be exempted from any disclosure requirements.

\section{Will Disclosure Reveal Proprietary Information?}

Opponents of disclosure assert that revealing the amount of a corporation's taxes or credits would reveal proprietary information, but no one has even been able to present a viable example of this.

One does not hear this type of argument being made any more about the copious information that federal laws force corporations to reveal. SEC and other federal laws already require many corporations to disclose tax and financial information, and such disclosures have not jeopardized the economic interests of the corporations.

Further, for information to be valuable, one needs to know yesterday what a competitor is going to do tomorrow. But by the time a corporation requests the normal extensions and files its return, whatever tax information would be disclosed would be stale. Yesterday's information obtained tomorrow is worthless.

\section{Will Disclosure Discourage the Filing of Accurate Tax Returns?}

A commonly stated rationale for protecting the confidentiality of tax information, at least for individuals, is to facilitate tax enforcement by encouraging a taxpayer to make full and truthful declarations in its return, without fear that those statements would be revealed or used against it for other purposes.

Contrary to the thesis that secrecy induces honest reporting, if corporations were publicly accountable for the information furnished on their income tax returns, their incentive to report truthfully might be even greater. Publicity could increase the possibility that employees, competitors, or other business persons would notice glaring omissions and bring them to the attention of the tax authorities.

\section{Will Disclosure Undercut a State's "Business Climate"?}

Opponents of disclosure argue that it would create or exacerbate an antibusiness climate in the state. This argument proves too much. Any legislation that the corporate community opposes can be characterized as poisoning the business climate.

Many considerations affect a corporation's view of a state's business climate -- plant or site availability, 
access to and cost of transportation, quality and cost of labor, proximity to markets, cost of utilities, proximity to supplies, proximity to other company facilities, the regulatory environment, cost of housing, the level and quality of public services, and the range of factors that determine the general quality of life offered to a firm, its employees, and their families. Unlike most of the factors that affect a state's business climate, the disclosure of corporate tax information would not affect the cost of doing business or a corporation's "bottom line." No one has ever argued that the extensive reporting requirements of the SEC have damaged the U.S. business climate or that Wisconsin's longstanding disclosure law has hurt that state's economy.

\section{Conclusion}

The current debate over the disclosure of state corporate tax data has very deep roots. At the national level, starting with the Civil War income taxes, there was a robust debate over the extent to which the public should have access to federal tax information of both individuals and corporations. This debate, however, primarily centered on individuals and their rights of privacy rather than on large corporations; when corporations entered the discussion at all, it was typically in terms of concern for the privacy of "mom and pop" operations that could be viewed as the alter ego's of their owners. The few times when Congress concentrated on the differences between individuals and corporations, it recognized that legitimate reasons existed for granting more public access to corporate data than to individual data.

The SEC has essentially resolved the federal debate by imposing extensive financial reporting responsibilities on publicly-traded corporations, including the release of detailed information on federal income taxes and the aggregate amount of state income taxes. Proposals for state-disclosure would require that the state income tax information be disaggregated and presented in greater detail. These proposals are intended to facilitate thoughtful tax policymaking and more accountability and openness in government. They would also complement the SEC-mandated disclosure.

Compared with the much more extensive reporting requirements already imposed on corporations by other federal and state statutes and with the amount of financial information now in the public domain, proposals for state level disclosure are clearly unexceptional in terms of both the administrative burden involved and the type of data covered. The virtues of disclosure were graphically demonstrated by the efforts of Citizens for Tax Justice (CTJ) at the federal level, which resulted in many of the corporate tax changes in the Tax Reform Act of 1986. Perhaps it is the fears of those who are benefitting from the flaws in the current corporate tax system, more than any inherent defect in the proposals, which explain the contentious opposition of elements of the business community in Massachusetts, the one state that has adopted a comprehensive approach to state tax disclosure. In theory, the 
business community, as a whole, should be supportive of attempts to improve and rationalize government policymaking.

Most of the arguments against disclosure, similar to the arguments often raised against proposals that threaten the status quo, involve the incantation of threadbare and shopworn slogans. Others are based on speculation and unsupported assertions. While some opponents are undoubtedly sincere in their fears, their arguments fall well short of rebutting the benefits that would accompany disclosure. 


\section{Introduction}

One of the catalysts for the Tax Reform Act of 1986 was the efforts of Citizens for Tax Justice (CTJ), a Washington-based think tank. Working with data from annual reports to shareholders and to the Securities and Exchange Commission (SEC), CTJ documented that some of the largest, most profitable corporations in the country were paying little or no federal income tax. Indeed, General Electric during a three year period actually received tax refunds of $\$ 283$ million despite pre-tax domestic profits of over $\$ 6.5$ billion. Six other companies--Boeing, Dow Chemical, Tenneco, Santa Fe Southern Pacific, Weyerhaeuser, and Du Pont--received net benefits or refunds in excess of $\$ 100$ million each, notwithstanding profits totalling $\$ 9.8$ billion. ${ }^{1}$

According to Rep. Dan Rostenkowski, Chairman of the House of Representatives Ways \& Means Committee, the public outcry that resulted from the disclosure of the nominal federal income taxes paid by some of the largest corporations in the country was one of the keys to the sweeping 1986 changes that broadened the base, lowered the rates, and provided more uniform treatment of taxpayers. "When people look at their own tax bills and then hear that big, profitable corporations are able to manipulate the system to escape taxation, $\mathrm{Mr}$. Rostenkowski said, 'that's when the revolution comes."'2
CTJ's work had a profound effect on educating the public about the need for corporate tax reform, and the 1986 Tax Reform Act was ultimately supported by many in the business community. ${ }^{3}$ But CTJ's work cannot be replicated at the state level. SEC reports and annual shareholder reports contain information on the aggregate amount of state and local income taxes but the information is not broken down state-by-state. ${ }^{4}$ And, until very recently, only Wisconsin allowed the public to obtain information on the amount of state income tax paid by specific corporations. $^{5}$

In the past several years, attention has turned increasingly to the states. Cutbacks in federal aid, the recession, which continues to plague parts of the country, and other factors have resulted in ongoing budget problems. In many states, corporate tax payments have declined and varied in ways that seem unrelated to economic conditions.

These developments, together with the increasing number of corporate tax incentives being enacted at the state level, have led many analysts to conclude that information about the impact of state tax systems on specific corporations is necessary for intelligent tax policymaking.

Corporations pay over $\$ 20$ billion yearly in state corporate income taxes, but the lack of information on the amount of state income tax paid and credits taken
The public outcry that resulted from the disclosure of the nominal federal income taxes paid by some of the largest corporations in the country was one of the keys to the sweeping 1986 changes that broadened the base, lowered the rates, and provided more uniform treatment of taxpayers. 
Even before SEC-mandated disclosure, the amount of income taxes paid by corporations and even individuals were at various times public information. by specific corporations in each state makes it impossible to evaluate the extent to which the corporate tax burden is allocated fairly or rationally in relationship to measures of profitability. Nor is it possible to analyze accurately the effectiveness of the billions of dollars being expended annually in state tax incentives because it is not known which corporations receive what type of incentives and in what amounts.

In 1987, an unpublished but widely circulated study by the staff of the New York Tax Study Commission concluded that the amount of state corporate income taxes paid and other related information should be publicly available on a corporation-bycorporation basis. ${ }^{6}$ In the last few years, three states have adopted laws providing for some state-level disclosure by corporate name. Arkansas and West Virginia make available by name of taxpayer-both individuals and corporations-the amount of selected credits claimed. In Massachusetts, publicly traded corporations, banks and most insurance companies, doing business in the state, will soon file an array of state tax information that will then be available for public inspection on a corporationby-corporation basis. ${ }^{7}$ The rest of the states prohibit the disclosure of any corporate tax data by name of corporation. ${ }^{8} \quad$ A number of states, however, are considering changing their laws to provide greater public access to corporate tax information. ${ }^{9}$

Proposals calling for the release of information on the amount of state corporate income taxes paid and other tax-related data on a corporation-by-corporation basis have been treated as innovative, if not radical. This reaction, however, overlooks the extensive nature of the financial information, including tax information, that is already in the public domain because of SEC regulations and generally accepted accounting principles (GAAP). ${ }^{10}$

Even before SEC-mandated disclosure, the amount of income taxes paid by corporations and even individuals were at various times public information. In the 1920's, for example, newspapers trumpeted this information on their front pages. ${ }^{11}$ Even today, a bona fide shareholder of record who owns at least $1 \%$ of a corporation can inspect its tax return and that of its subsidiaries (but cannot disclose anything obtained from the inspection). ${ }^{12}$

Rather than being extraordinary, calls for disclosure are based on rather traditional values -- that the public as well as elected officials should be informed about the workings of our economic and legal systems; and, that, to the maximum extent possible, public policy should be made in an open and informed manner.

Section II of this report traces the history of public access to federal tax returns. Besides debunking the common perception that corporate tax returns have always been immune from public scrutiny, this historical survey reveals a different story. The privacy issue was basically fought over the issue of whether individual--not corporate--tax returns should be public 
information. When corporations entered this debate at all, it was essentially with regard to the privacy of "mom and pop" businesses, which were viewed as the alter ego's of their owners. Further, the last chapter of this Congressional debate occurred during the early 1930's and was colored by the Lindbergh kidnapping and the crime wave that marked the Great Depression. Individuals feared that if their returns were made public, they would be marked by kidnappers, con artists, and those of similar ilk. By way of contrast, when the issue of whether corporate taxes should be private was debated in 1909 independently of individual returns, Congress opted for public disclosure.

Section II also reviews the disclosure of income tax information that is currently mandated by the SEC under its own regulations and by its requirement that corporations under its jurisdiction follow GAAP. In fact, the amount of income tax data now required to be disclosed by the SEC and GAAP far exceeds anything that proponents of disclosure ever hoped to obtain from Congress.

Section III examines the experiences of the four states that have adopted some form of corporate tax disclosure legislation: Massachusetts, West Virginia, Arkansas, and Wisconsin.

Section IV analyzes the cases for and against state-level disclosure and concludes that there is an overwhelming case in favor. Consequently, Section V discusses the key issues involved in the design and implementation of statelevel disclosure laws.
The privacy issue was basically fought over the issue of whether individual--not corporate--tax returns should be public information.

By way of contrast, when the issue of whether corporate taxes should be private was debated in 1909, independently of individual returns, Congress opted for public disclosure. 


\section{The Disclosure of Income Tax Information at the Federal Level: An Historical Perspective}

This section traces the history of public access to federal tax returns and tax return information. It also reviews the disclosure of income tax information that is currently required by the U.S. Securities and Exchange Commission, and by Generally Accepted Accounting Principles.
The heart of this Section is a study of the public's access to federal tax return information, organized chronologically around six key time periods. The first is marked by the Civil War income taxes, which at one time provided for the publication of the names of individuals and the amount of taxes they paid (the Civil War income taxes did not apply to corporations). By the end of the war, however, Congress prohibited this practice.

The short-lived 1894 Income Tax apparently reflected the still lingering hostility to the disclosure of tax information during the Civil War because Congress again made it unlawful to publish income tax data.

The next important event occurred with the Tariff Act of 1909, the predecessor of the modern corporate income tax. Significantly, the 1909 law provided that corporate returns should be open to inspection. Almost immediately, opponents of disclosure started to emasculate this provision and after some political vacillation, Congress provided that corporate returns should be open to inspection upon order of the President under rules prescribed by the Secretary of the Treasury and approved by the President.

The 1913 Income Tax, the predecessor of today's personal income tax, carried over this provision. However, this power was never exercised very broadly by any president. In reaction, proponents of disclosure pressed for broader laws and achieved some minor victories starting in 1918.

The zenith of the Congressional tax disclosure movement occurred in 1924 when the public was provided access to the names of corporations, as well as individuals, and the amount of taxes they paid. Two years later, a backlash was successful in narrowing the law to provide access to only the names of taxpayers filing returns but not the amount of taxes paid.

Advocates of disclosure achieved a hollow victory in 1934 with the infamous "pink slip" provisions. Corporations and individuals were required to file a pink slip with their tax returns containing information on income, deductions, credits, and tax liability. These slips were to be available for public inspection. Before the effective date of this requirement, however, a well orchestrated pink slip rebellion occurred and the law was repealed. This was the last time Congress debated the general public's access to tax return information. The final part of this Section describes the extensive disclosure of financial and income tax data mandated by the SEC and GAAP. 


\section{A. The Civil War Income Taxes: 1861-1872}

The original Civil War Income Tax Act, passed in $1861,{ }^{13}$ provided that "the said taxes, when so assessed and made public, shall become a lien on the property or other sources of said income for the amount of the same..."14 This provision was apparently the only reference to whether tax information was to be public. ${ }^{15}$ Because the 1861 Act never became effective $^{16}$, no information exists on how this provision was intended to be interpreted. The 1862 Act, $^{17}$ which replaced the 1861 Act, was more explicit. The 1862 Act provided for a period of 15 days in which the public could examine the names of taxpayers and the amount of their liabilities. ${ }^{18}$ The public was notified of this opportunity through newspaper advertisements and posted notices. Similar provisions were made for publicizing the collectors lists. ${ }^{19}$

The reasons for publishing the amount of taxes owed were presumably that in an era without mass communication, sufficient administrative procedures or machinery, or reliable mail systems, the posting of both "assessor's lists" and "collector's lists" in public places was a means of notifying taxpayers, first, that they owed taxes; second, of the determination of their taxable income and tax liability; and finally, of the impending arrival of the tax collector. ${ }^{20}$ Representative Porter of Indiana echoed this consensus about the purpose of the publicity feature: "Now, what is the object of the [publicity] feature?
Obviously, it is to give the tax payer time to collect his money in order to be ready when the collector arrives." 21

Initially, the 1862 Act was not interpreted as permitting public examination of the underlying tax information. $^{22}$ Early in 1863, the Commissioner directed that returns should be available only to tax officials $^{23}$ so that the income tax "might not be felt to be inquisitorial."24 Newspapers strongly urged that they be allowed to print tax returns and in a second ruling, the Commissioner acceded. ${ }^{25}$ The Commissioner defended his action as providing "the amplest opportunity...for the detection of any fraudulent returns that may have been made." ${ }^{26}$ The 1863 legislative recommendation of the Secretary of the Treasury was to the contrary, however, requesting that Congress prohibit disclosure of tax returns. ${ }^{27}$

The Revenue Act of 1864 disregarded this recommendation, by providing that the assessors "submit the proceedings of the assessors . . . and the annual lists taken and returned to the inspection of any and all persons who may apply for that purpose." 28 Newspapers began publishing lists of reported incomes and taxes paid. $^{29}$

Not all newspapers favored disclosure, although some changed their positions on this issue over time. At the end of 1864, the New York Times lamented the lack of secrecy. ${ }^{30}$ A month later, the New York Tribune published a list of incomes and an editorial supporting its decision: "So long as an income tax shall be required
Not all newspapers favored disclosure, although some changed their positions on this issue over time. At the end of 1864, the New York Times lamented the lack of secrecy. 
About 18 months later, the New York Times shifted its views to those of the Tribune and stated that publicity prevented collusion between taxpayers and collectors and that only by making tax returns public could full compliance be secured. and levied, we are satisfied that it is best for all who are honestly concerned therein that there should be no restriction on giving publicity to the items." ${ }^{13}$ About 18 months later, the New York Times shifted its views to those of the Tribune and stated that publicity prevented collusion between taxpayers and collectors and that only by making tax returns public could full compliance be secured. The Times asserted that in 1864 and 1865 the publicity provisions generated millions of dollars to the government. $^{32}$ The Commercial and Financial Chronicle argued in opposition that publicity led to the falsification of returns for the purpose of ostentation and for securing credit. ${ }^{33}$

By the end of the Civil War, it was customary for newspapers to publish income tax information. ${ }^{34}$ Horace Greeley concluded that publicity "has gone far toward equalizing the payments of income tax by the rogues with that of honest men." ${ }^{135}$ The New York Times continued supporting publicity:

"Show every taxpayer's sworn return of income to his nearest neighbors, his most intimate friends, to himself, indeed, in public journals, and you have a security that no laws, no oaths, and no scrutiny, has or can furnish. In no other way can the income tax law be so efficiently and so searchingly executed and enforced as by the regularity and certainty of the publication of income assessment lists. ${ }^{136}$

There were also more assertions that public disclosure had helped increase revenue. ${ }^{37}$

While there was certainly a splintered voice of opposition to disclosure from the start, "objections appeared to arise more frequently [only] when the major newspapers began to publish the incomes of the leading citizens." ${ }^{138}$ Representative (and later President) Garfield argued that tax returns should be available to the public but should not be published by newspapers:

"Suppose a man has had serious losses during the year, so that his income would be smaller than people expect it to be. Now, he would not want to let that be known so as to alarm his creditors and bring them all down upon him when otherwise he would come out safely. There is no reason in the world, unless the public interest require, that the private affairs of individuals should be brought out and paraded in the public papers. I admit that some form of publicity is necessary to act as a pressure upon men to bring out their full incomes, but if the lists are left open for public inspection it will be an ample pressure upon them. ${ }^{139}$

Arguments such as Garfield's were reinforced by assertions that as tax officials gained experience, citizenwatchdog assistance was less needed and less justifiable. ${ }^{40}$

As the post Civil War income tax became unpopular, the publicity feature was also attacked. In 1869 , the New York Times reverted to its earlier position opposing disclosure, arguing that a properly organized revenue force could prevent evasion 
and obviate the nuisance of publicity. ${ }^{41}$ It denounced the publishing of returns as "offensive and objectionable." 42

In 1870, a new Commissioner prohibited assessors from furnishing tax lists for publication, although the public was still allowed to inspect returns. ${ }^{43}$ This position, which mirrored Garfield's views, was apparently taken in the hope of "lowering voices" over this increasingly contentious issue. ${ }^{44}$ Congress responded to complaints about disclosure in 1870 by providing that "income tax returns or any part thereof. ... shall not be published." 45 The Civil War Income Tax died at the end of 1871, in part due to the rising concerns over privacy, not entirely put to rest by the 1870 statutory revision. ${ }^{46}$ Because the Civil War income taxes applied to individuals and not to corporations, these concerns about privacy were limited only to individuals. ${ }^{47}$

\section{B. The 1894 Income Tax}

The memory of these concerns, and of the demise of the income tax that the publicity provisions had partly caused, was reflected in the non-disclosure provision of the short-lived revival of the income tax in 1894. ${ }^{48}$ The 1894 Act provided: "it shall be unlawful for any person to print or publish in any manner whatever not provided by law, any income return or any part thereof." ${ }^{49}$ "During floor debates, no discussion of the privacy aspect of the bill appears to have occurred. Therefore, it may only be felt that the lessons of the Income Tax Act of 1862 were found carried into the drafting of the Income Tax Act of 1894, and tax return confidentiality was thought a significant requirement." ${ }^{50}$ When the tax was held unconstitutional in $1895,{ }^{51}$ the Commissioner ordered all income tax returns already collected to be burned. ${ }^{52}$

Although the earlier Acts had only taxed individuals, ${ }^{53}$ the 1894 Act was an income tax on both individuals and corporations. ${ }^{54}$ Thus the privacy extended to corporate income tax returns in 1894 was adopted without the benefit of any debate, by virtue of the lingering public sentiment about the privacy of individual returns. When, however, Congress adopted a tax on only corporations, as was true in 1909 , it was willing to move in the direction of disclosure.
Although the earlier Acts had only taxed individuals, the 1894 Act was an income tax on both individuals and corporations. Thus the privacy extended to corporate income tax returns in 1894 was adopted without the benefit of any debate, by virtue of the lingering public sentiment about the privacy of individual returns. 
Because the 1909 Act did not apply to individuals, this was the first time the disclosure issue was debated solely in the context of corporations. Contrary to the 1894 Act, it provided that corporate returns "shall constitute public records and be open to inspection as such."
Senator Bourne also felt that disclosing corporate returns would uncover and discourage dishonest business practices and bookkeeping. "All legitimate business should welcome this legislation, and only the business pirate need fear and oppose it.

\section{The Tariff Act of 1909}

In 1909, the Payne-Aldrich Tariff $\mathrm{Act}^{55}$, the predecessor of the modern corporate income tax, was passed, and the disclosure issue was resurrected. Because the 1909 Act did not apply to individuals, this was the first time the disclosure issue was debated solely in the context of corporations. Contrary to the 1894 Act, it provided that corporate returns "shall constitute public records and be open to inspection as such." ${ }^{56}$

There are no statements in the hearings or reports regarding the underlying rationale for this provision, ${ }^{57}$ but from the floor debate and surrounding events, it becomes clear Congress was willing to adopt a different privacy standard for corporations than for individuals. By 1909, the growing labor movement and the still-fresh legacy of former President Roosevelt's well-publicized trustbusting campaign had created a widespread popular distrust of corporations. Although "[t]he legislative history does little to illuminate [the publicity] provisions," ${ }^{58}$ it seems likely that the new national mood had much to do with the reversal of disclosure policy.

Floor debate on the Act provides a barometer of the country's mood. Senator Jonathan Bourne (R Ore.), for example, praised the publicity provisions as follows: ${ }^{59}$

"[T]he Government, at least, will have cognizance of all corporation earnings, and a method is provided by which the stockholders may secure such information, since the returns to the Government become public records. Thus will be eliminated in the future the possibility of concealed equities; corporation 'melon cuttings' will be done away with; the responsibility of corporation management to all the stockholders will be established; the holder of one share of stock will have opportunity of acquiring as much information concerning corporation affairs as the owner of 100,000 shares.

Corporations will be popularized and "peoplearized;" the tendency will be for people to invest their earnings in corporation securities on the assumption that the publicity feature and greater opportunity for governmental supervision will protect their investments..."

Senator Bourne also felt that disclosing corporate returns would uncover and discourage dishonest business practices and bookkeeping. "All legitimate business should welcome this legislation, and only the business pirate need fear and oppose it."60 To Senator Bourne, the public disclosure of corporate returns was one of the most significant provisions of the corporate income tax. ${ }^{61}$ Other senators, who only marginally supported the corporate income tax law itself, were nonetheless strong defenders of the disclosure of corporate returns. ${ }^{62}$ 
President Taft, who vigorously defended the disclosure of corporate income tax returns, played an important part in winning the support of the progressive element of the Republican Party. ${ }^{63}$ He believed that the publicity feature of the law was more valuable than the tax's revenue potential. ${ }^{64}$

Shortly after passage of the 1909 Act, opponents started an active campaign to emasculate the publicity features. Small corporations, especially those whose securities were not listed on exchanges, and thus were not used to providing any public information, lobbied hard against the broad 1909 publicity feature. ${ }^{65}$ This opposition was spearheaded by the Illinois Manufacturers' Association, which held a conference of industrial and commercial associations in 1910, described as "the first gun for a national movement which has in view the uniting of all" ${ }^{16}$ seeking to eliminate disclosure. The basic argument was that the disclosure provisions discriminated between the larger and smaller corporations and between corporations and partnerships and proprietorships. ${ }^{67}$

Within a month of the 1910 conference, the Commissioner issued his first decision on administering the publicity features. He ruled that because Congress had made no specific appropriation for public inspection of the returns, they would be treated as confidential. ${ }^{68}$ In effect, this ruling suspended the publicity provisions unless Congress acted. The Illinois Manufacturers' Association in their published literature claimed credit for this administrative victory. ${ }^{69}$

In response to the Commissioner shifting the onus onto the legislative branch, Congress appropriated $\$ 25,000$ for the purpose of classifying, indexing, and exhibiting tax returns, ${ }^{70}$ but provided the significant condition that "any and all such returns shall be open to inspection only upon order of the President under rules and regulations to be prescribed by the Secretary of the Treasury and approved by the President."71 Presumably, Congress intended by this provision to back away from the public disclosure of corporate returns. ${ }^{72}$ Some felt this compromise sorely undermined the benefits of the publicity feature and granted too much power to the President. Representative Oscar Underwood (D-Ala.), for example, argued: "If you pass this amendment and the President of the United States wants to use the publicity as a whip over any corporation of this country, he can do so. If you are going to have publicity of any kind, why not have honest, straightforward, full publicity and let all the world know what is going on, and not a subterfuge of this kind." 73

Pursuant to this Congressional delegation, the Secretary of the Treasury, with the approval of the President, provided access to corporate returns under two broad circumstances. First, bona fide shareholders could apply for permission to inspect the tax returns of their corporations; they would have to make a showing of cause, and it was discretionary with the
President Taft, who vigorously defended the disclosure of corporate income tax returns, played an important part in winning the support of the progressive element of the Republican Party. He believed that the publicity feature of the law was more valuable than the tax's revenue potential. 
Progressives argued that publicity would end improper trade policies, business methods, and conduct, and would assure fuller and more accurate reporting by taxpayers.
Secretary whether to grant permission. Second, anyone could inspect the returns of corporations listed on exchanges, or those whose stock was advertised in the press or offered for public sale by the corporation itself. ${ }^{74}$ Returns could only be inspected, however, at the office of the Commissioner and there were no provisions for furnishing a copy of any return to any person. ${ }^{75}$ Further, the law made it unlawful for anyone to print or publish in any manner whatever not provided by law, any income tax return or any part thereof. ${ }^{76}$ The commonly accepted interpretation of this provision was apparently that it prevented the publication of information obtained from inspecting returns.

\section{1913 - 1923}

The 1913 Act imposed an income tax on individuals and corporations. The law mirrored the 1910 changes regarding disclosure. Tax returns "shall constitute public records and be open to inspection as such: Provided, That any and all such returns shall be open to inspection only upon the order of the President, under rules and regulations to be prescribed by the Secretary of the Treasury and approved by the President."17 The President, however, did not exercise his authority to provide public inspection of individual tax returns ${ }^{78}$ allowing Progressives in Congress to debate access to income tax returns during the consideration of subsequent revenue acts. ${ }^{79}$ Progressives argued that publicity would end improper trade policies, business methods, and conduct, and would assure fuller and more accurate reporting by taxpayers.

In 1918, advocates of disclosure nibbled away at the President's discretionary power by requiring the Commissioner to make available for public inspection in the offices of every collector, and elsewhere in his discretion, lists enumerating the names of individuals, but not corporations, who had filed returns in that district. $^{80}$ The law was also amended to grant to a bona fide shareholder of record who owned $1 \%$ or more of the outstanding stock of a corporation the right to examine the annual income tax returns of such corporations and its subsidiaries. ${ }^{81}$ The law provided, however, that it was a misdemeanor punishable by a fine not exceeding $\$ 1,000$ or by imprisonment not exceeding one year for a shareholder to make "known in any manner whatever not provided by law the amount or source of income, profits, losses, expenditures, or any particular thereof, set forth or disclosed in any such return." 82 Presumably, this provision would be violated if a shareholder published in a newspaper the amount of tax paid by a corporation. Also reissued were the regulations allowing the public the right to inspect returns of listed or publicly-sold corporations and allowing any shareholder, at the discretion of the Secretary of the Treasury, upon a proper showing of cause, to inspect the return of his or her corporation. ${ }^{83}$ 
The right of $1 \%$ or more shareholders to examine the income tax returns of their corporations still exists, along with the prohibition on disclosing information obtained. ${ }^{84}$

\section{E. The 1924 and 1926 Acts}

By 1924, the public disclosure of income tax returns had become a rallying cry for farm-bloc Senators, who warned that "secrecy is of the greatest aid to corruption" and urged that "to-day the price of liberty is not only eternal vigilance [sic] but also publicity." ${ }^{85}$ Forces calling for disclosure achieved some success in the Revenue Act of 1924, which required the names of both individuals and corporations filing returns to be posted, along with, significantly, their tax liabilities. ${ }^{86} \quad$ Although some advocates of disclosure wanted the entire return published ${ }^{87}$ questions were raised about whether this would seriously hamper the routine work of the Bureau of Internal Revenue. ${ }^{88}$

The 1924 change was supported by Democrats and insurgent Republicans. ${ }^{89}$ Supporters offered two principal arguments: (1) publicity would discourage tax evasion, promote honesty, and increase revenue; and (2) publicity would end improper trade policies, business methods, and conduct. ${ }^{90}$ Publicity was bitterly opposed by Secretary of the Treasury Mellon, Senator Smoot, Secretary of Commerce Hoover, ${ }^{91}$ and Representative Ogden L. Mills, who would later become Secretary of the Treasury under President Hoover. They maintained that publicity had failed to increase revenue in the past and actually encouraged tax evasion, and led to undesirable newspaper gratification of public curiosity. ${ }^{92}$ When President Coolidge signed the bill, he issued a statement objecting inter alia to the publicity provisions. ${ }^{93}$

These provisions apparently raised almost no popular indignation until tax information was printed in the newspapers a few days before the 1924 election. ${ }^{94}$

"Although some newspapers refused to publish this information, coverage was extraordinarily comprehensive. Whole pages were devoted to lists of payments by local citizens. Feature stories reported on the biggest corporate assessments and the tax payments of prominent out-of-towners like Babe Ruth or Standard Oil. Teasers told of divorcees who were investigating their husband's income and wealthy taxpayers who escaped with paltry tax payments. ${ }^{1195}$

The New York Times and other newspapers devoted entire pages to publishing the taxes paid by thousands of persons. ${ }^{96}$ Enterprising persons published pamphlets containing the names of taxpayers and the amounts they paid. $^{97}$ The U.S. Supreme Court upheld the right of newspapers to print the lists made public. ${ }^{98}$

The New Republic added a new twist in its defense of the publicity provisions, by focusing on how many person's salaries were already
The right of $1 \%$ or more shareholders to examine the income tax returns of their corporations still exists, along with the prohibition on disclosing information obtained. 
Supporters of the 1924 law declared that it would reveal the illegal practices of tax evaders, apparently by drawing attention to suspiciously low payments. public information:

First. . . are. . the [e]mployees of cities, counties, states, and nation-the laborers, street-sweepers, firemen, policemen, clerks, stenographers, mail-carriers, bookkeepers, teachers, librarians, scientists, accountants--all those whose salaries are fixed by public authority and printed in official reports, the worth of whose work is a regular subject of debate, who must usually make heroic efforts to exhibit the inadequacy of their incomes in order to secure tardy increases. Next march the serried divisions of the employees of private industry who receive their recompense in wages...The hourly or weekly rates paid... are published in official documents... Last of all march the multitude of farmers who...cannot count much on secrecy when the yields and prices of their crops are so obvious. ${ }^{199}$

According to the New Republic, the existing law did not go far enough. "Little, after all, can be learned concerning the evasions or the incomes received merely from records of the taxes paid. Full publicity of the returns themselves is the only logical procedure. The government now has gone far enough to cause irritation to the taxpayer and the public, but not far enough to reap the substantial benefits of candor." ${ }^{100}$

Supporters of the 1924 law declared that it would reveal the illegal practices of tax evaders, ${ }^{101}$ apparently by drawing attention to suspiciously low payments. The New York Times, however, carried front page stories about how income tax collectors felt that the publication of individual tax returns had no appreciable effect on tax administration. ${ }^{102}$ Yet the Times also published on its front page the names of wealthy and prominent New Yorkers who paid no income tax, which presumably would have led to inquiries by the tax administration. ${ }^{03}$ Other editorials attacked the new law as unnecessary because most persons are honest and in any event, the government maintains a large force of inspectors to check doubtful cases.

By now, the anti-disclosure rhetoric was predictable. Disclosure was criticized as "flagrantly undemocratic, exposing to the general gaze the affairs of only a small minority. It is petty, furnishing food for the impudent curiosity of gossips and busybodies. It opens a door to business fakers, offering them choice lists of moneyed 'prospects.' It furnishes confidential information of a certain value to a business man's rivals." 104 "Partners are checking up on each other; husband and wife are on the fiscal trails of their mates, alimony hunters are running wild, and 'sucker lists' of the wealthy are being prepared by those who have something to sell....Economically, the new policy will be costly; morally, it is indefensible; socially, it is deplorable...Decent Americans will not care to act as spies, and, we believe, they will bitterly resent being spied upon." ${ }^{105}$ "Those forgotten men who do the work and pay the bills and the taxes, who 
honestly fulfill their duties as citizens, who try to obey even the most whimsical and capricious laws, who discharge their public and private obligations honorably and decently--how long will they consent to this exposure of their private affairs to the eager eyes of the scandal-monger, the blackmailer, the parasite, and the taunt?"106 "[T]he land is filled with a luxuriant crop of envy, suspicion, hatred, insinuation and innuendo, much of it false and unfair; for the honesty of an income-tax return cannot be determined by the mere amount of payment in a single year.....The publication of the amount of tax paid is not only unfair; it confuses still more both the understanding and the administration of the income tax.....Sensible people, whether tax experts or those without pretensions to specialized knowledge in this field, know that the only way to make the income tax fairer and more equitable is gradually to lighten it."107

Information on the taxes paid by prominent persons was used by one journal to support Secretary Mellon's call for reduced income surtaxes.

"John D. Rockefeller, Jr., [paid] about \$7,000,000; and Secretary Mellon, \$1,173,987. In these cases, where the highest surtaxes are operative, the Government is obviously not imposing a levy on the rich man's extravagances. It is safe to assume that neither Mr. Rockefeller nor Mr. Mellon deprive themselves of any indulgences to meet their tax bill; they pay their taxes out of their industrial funds. The tax amounts to a levy on industry, a diversion of capital from business channels into Government channels. High surtaxes are not so much a personal blow to the inordinately wealthy as a graduated penalty inflicted upon industries in direct proportion to their prosperity. A tax that punishes efficiency and success may gratify the passions of business-baiters, but is not just and is hardly conducive to the welfare of the country. "108

In his annual message to Congress at the end of 1924, President Coolidge voiced his opposition to disclosure:

"Every one desires a reduction of taxes, and there is a great preponderance of sentiment in favor of taxation reform. When I approved the present tax law I stated publicly that I did so in spite of certain provisions which I believed unwise and harmful. One of the most glaring of these was the making public of the amounts assessed against different income tax payers. Although that damage has now been done, I believe its continuation to be detrimental to the public welfare and bound to decrease public revenues so that it ought to be repealed. "109

Secretary of the Treasury Mellon expressed similar sentiment:

"Publicity is wholly unnecessary from an administrative standpoint. Publicity serves one purpose, however. It gives to business rivals and to those having some ulterior
Information on the taxes paid by prominent persons was used by one journal to support Secretary Mellon's call for reduced income surtaxes. 
"It is difficult to image any one thing which would be a greater spur to the efforts of all taxpayers to avoid a taxable income than the threat that the amount they paid will be pilloried."

- Treasury Secretary Mellon motive information which is of value to them solely to the extent it is detrimental to the taxpayer. They gain by the taxpayer being hurt.

"It is difficult to image any one thing which would be a greater spur to the efforts of all taxpayers to avoid a taxable income than the threat that the amount they paid will be pilloried. To the direct monetary value of saving payment of an inherently high tax is added the incentive, in many cases much stronger, of preserving business privacy.

"Immediately upon the recent publication of this information opened to the public, the newspapers reported a stimulation in the market for tax-exempt securities. We may promptly expect renewed use of the many means of tax avoidance, with the consequent decrease in the productivity of the income tax. The provision should be repealed."110

Consistent with Secretary Mellon's opposition, Treasury officials asserted that they were unable to point to a single case in which a tax dodger had been uncovered as a result of public disclosure. For example, the Treasury reported over 13,000 persons had neglected to file a return of their income in 1925-some of whom were bootleggers-and that the names of these persons did not appear on the lists that were published. ${ }^{111}$ Treasury officials asserted that public disclosure had not had the effect of increasing revenue from delinquents, that the data made available for publication were of no particular value, and that disclosure was an added expense to the federal government for which there was no offsetting benefit. ${ }^{112}$

In 1926, the vehement opposition of Treasury Secretary Mellon, ${ }^{113}$ representatives of big business, ${ }^{114}$ and President Coolidge, led to the law being altered to require the posting of only the names and addresses of taxpayers and not the amount of their liabilities. ${ }^{115}$ This change, intended to placate the champions of disclosure, ${ }^{116}$ essentially remained law until 1966. ${ }^{117}$ According to one commentator, the change successfully prevented the "spotlight from being thrown in the future on the hierarchy of wealth which had come to dominate American society. . . . The resulting public concern about the concentration of wealth," that was triggered by the 1924 publicity provisions, "impelled Mellon and his associates to safeguard their privileged positions by keeping from the public vital facts about the individuals who composed the high income elite." 118

\section{F. The Pink Slip Provisions: 1934 - 1935}

No further changes in the law occurred until $1934 . \quad$ The groundwork for the 1934 changes was laid by a well publicized scandal involving income tax evasion that arose during consideration of the National 
Industrial Recovery Act (NIRA).

Senator Robert LaFollette, Jr., who had inherited the cause of income tax disclosure from his father, declared that the "unconscionable evasions and understatements of income revealed by the investigation of the Senate... would never have taken place [had disclosure been in effect]." 119 LaFollette seized the opportunity by proposing an amendment for full publicity, which sailed through the Senate on a $56-27$ vote. ${ }^{120}$ The Conference Committee, however, informed by Treasury experts that publicity would be administratively "cumbersome," left the issue of disclosure once again to the President's discretion. ${ }^{121}$ Progressives were infuriated, and joined en masse with Republicans to nearly sink the NIRA Conference package. ${ }^{122}$

Progressives were keenly aware of the Treasury's opposition to publicity and skeptical of President Roosevelt's inclination to use his discretionary power to broaden public access to tax returns. When their skepticism proved correct, the Senate attached LaFollette's full publicity amendment to the 1934 Revenue Bill. ${ }^{123}$ Although Congress refused to publicize the

complete income tax return, it did authorize the so-called pink slip requirements. ${ }^{124}$

Each taxpayer was required to fill out a pink slip with his or her return, containing name and address, total gross income, total deductions, net income, total credits, and tax liability. These slips were available for public inspection. The pink slip law also applied to corporations and partnerships.

Passed during the depths of the Depression, pink slip supporters played on the popular resentment toward the rich. ${ }^{25}$ Advocates thought disclosure would deter tax evasion. They claimed that there would be vast increases in tax payments by the wealthy once publicity incited public indignation. "Publicity is the greatest cure for evils which may exist in government." ${ }^{126}$ If someone "knows that his return is a matter of public record, he will hesitate a long time before he will resort to any device designed to relieve him of his fair share of the tax."127

Another rationale for disclosure was the automatic self correction in which "loopholes will be discovered immediately and legislation passed to correct evasions." ${ }^{128}$ Those advocating disclosure doubted the impartiality of employees of the Internal Revenue Bureau (the predecessor of the IRS) and argued that disclosure would keep tax administrators honest. ${ }^{129}$

Opposition to the pink slips was fierce and immediate.

A group calling itself the 'Sentinels of the Republic' mobilized the push for repeal before anyone would actually have to submit the [slips.] Its race with the March 15, 1935, filing deadline stirred wide press and popular support, for this time the question of access to tax returns loomed as a matter of life and death: The 1932 Lindbergh kidnap gripped the public con-sciousness. ${ }^{30}$

Senator Robert LaFollette, Jr., declared that the "unconscionable evasions and understatements of income revealed by the investigation of the Senate...would never have taken place [had disclosure been in effect]."
Another rationale for disclosure was the automatic self correction in which "loopholes will be discovered immediately and legislation passed to correct evasions." 
"The first group that will scan them carefully will be the racketeer, the gunman, and the possible kidnaper. In each small town throughout the country they will be interested in knowing whether a man could profitably be blackmailed or whether a kidnaping could possibly yield results."

- U.S. Representative Bacon, February 20, 1935
The Sentinels mailed approximately 12,000 letters throughout the country asking "Do you want the inquisitorial income publicity law repealed?" "It can be repealed if even 25 per cent of those citizens who resent it will express a demand for its repeal." The letter advised taxpayers to write across the pink slip "I protest against this outrage to my right of privacy!"131 The Sentinels of the Republic laid the groundwork for a massive taxpayer protest. Special anti-pink slip packets furnished taxpayers with propaganda sheets and a petition to Congress, urging them to write Secretary Morgenthau, their Congressman, and their local newspapers. When the Treasury sent out the pink slips and filing date for income taxes approached, an avalanche of indignant telegrams and letters, many of them identical, inundated Congress. In addition, many people affixed to their pink slips a sticker--available in the Sentinels' packet and at some banks-declaring "I protest against this outrageous invasion of my right of Privacy."132 This orchestrated protest apparently impressed Congressmen, who often commented that the bulk of the protests came from "the small taxpayers." 133

A common theme was that the information would be used for wrongful purposes. "The only people who can possibly be interested in this information will be a man's competitors or the idle and malicious curious."134 "With the country still in the throes of a terrible crime wave, many opponents voiced concern that pink slips would be red flags for criminals." ${ }^{135}$ "The Dillingers, the Carpis, and the 'Baby Face' Nelsons and their ilk will eagerly scan each list in his own community for a clue as to possible profitable victims." ${ }^{136}$ "The first group that will scan them carefully will be the racketeer, the gunman, and the possible kidnaper. In each small town throughout the country they will be interested in knowing whether a man could profitably be blackmailed or whether a kidnaping could possibly yield results. There is a fear going throughout the country because of this threat." 137 "Another group who will be very interested in this information will be those citizens who prey on defenseless widows and others by trying to sell them fake securities. Those who make up 'sucker lists' will be greatly aided." 38 "Many a person who lives in security may, upon publication of his tax return, be revealed as attractive prey for racketeers. As an illustration of publicity let me quote from a Washington paper of February 18, 1935: `Eleanor Hanley was hailed as an exceedingly lucky person when she won $\$ 110,000$ on the Irish Sweepstakes two years ago. This New Jersey woman has been hounded since by gangsters and is now in an asylum. Doctors hold she is unable to handle her affairs."'139

Others feared the effect of the pink slips on social harmony: "All those in the community on the list will be talked about, wondered about; talk will beget talk until ill feelings are bound to become engendered, resulting in the creation of social discord and indefinite damage to social standards." "I cannot begin in the short space of an evening, to uncover all the ramifications, embarrassments, distress, humiliation, and discouragements that will put themselves in the way of the smaller taxpayers unless this section is repealed." ${ }^{140}$ The disclosure movement had "been loyal in the cooking pots of demagogues whose ulterior motives are not the public interest, but class cleavage and the creation of class hatreds."141

The Saturday Evening Post described the pink slip provisions as "peculiarly stupid and half-baked," "grossly unfair," "it arouses prejudices and suspicions based on utterly misleading information." Some challenged the value of the information that would be made 
available. "It hurts the standing and credit of those who report abnormally small incomes because of depression conditions and poor collections. It makes other incomes appear abnormally large when they are not so at all, if various obligations, such as other taxes, contributions to charity, domestic complications, and dependents for whom deductions cannot be taken are considered..." "[S]o different are the sources of income of large or even moderate taxpayers...and so diverse are the deductions, that the facts contained in the pink slip were meaningless even to a trained accountant or an internal-revenue investigator. It is not only demagogic claptrap, it is quite untrue to say that the Government is prevented by secrecy from collecting taxes....Envy, malice, prejudice and passion are easy crops to raise, but raising them is as stupid as it is easy". ${ }^{42}$

The New Republic countered that the only good reason why any person would object to the release of income data was "because he is ashamed of its size or source; a good reason from his point of view, but certainly not from that of the community." ${ }^{143}$ Others argued that opponents of disclosure feared showing how well they had done under the New Deal:

[T]here are thousands of business men, manufacturers, and others whose return will show substantial profits in 1934, who in 1930, 1931, and 1932, under the Republican administration, suffered tremendous [losses]. It is these gentlemen who have been the beneficiaries of the new-deal legislation, who, under this provision will be compelled to make true returns showing that conditions have improved under the present administration .... ${ }^{144}$

No side had a monopoly on hyperbole. One supporter of the pink slips, for example, argued for "pitiless publicity . . . thrown upon the incomes of the rich, the superrich, and the idle rich," especially the "burglars of wealth, idle holders of idle capital, lounge lizards of the blue-blooded, and pink-toed aristocracy of wealth."145

The pink slip rebellion basically concerned individual returns and not corporate returns. Even when corporations were specifically mentioned, it was the "mom and pop" operations: "One of the most serious abuses that will be brought

Others argued that opponents of disclosure feared showing how well they had done under the New Deal:

[T]here are thousands of business men, manufacturers, and others whose return will show substantial profits in 1934, who in 1930, 1931, and 1932, under the Republican administration, suffered tremendous [losses]. 
The House Ways and Means Committee Report on the question of repealing the disclosure feature referred to the previous unsuccessful attempts at publicity without differentiating between corporate and individual returns, or between big and small businesses. The report focused almost solely on individuals. about by this section is the publication of business information to a man's competitor, and I am not at this moment thinking of large business or industry...but the smaller business men in the cities, and the small merchants in the towns of the country." 146

Representative Bacon wrote in a letter to the Chairman of the Committee on Ways and Means: "I do not think I need to give a summation of the reasons in opposition to the 'pink slip' section. However, I will say that most of the complaints I have received have been from people of modest means, small business men and the salaried or wage classes." ${ }^{147}$ The House Ways and Means Committee Report ${ }^{148}$ on the question of repealing the disclosure feature referred to the previous unsuccess-ful attempts at publicity without differentiating between corporate and individual returns, or between big and small businesses. The report focused almost solely on individuals.

The uproar over the pink slip provisions led to their repeal in 1935 before ever taking effect. ${ }^{149}$ The House Report recommending repeal argued that disclosure was unnecessary because "ample authority is contained in other sections of existing law authorizing the inspection of income-tax returns by the committees of Congress charged with the responsibility of levying taxation...[P]ublication... will be of slight benefit to the Treasury in the prevention of tax evasion, which is the main argument advanced for such publicity. The real remedy...is careful auditing of returns and the swift imposing of penalties for such evasion." 150

In addition, Congress cited unfavorably the experience of Wisconsin, the only state having a disclosure law at that time (presumably because of the influence of LaFollette). ${ }^{151}$ The House Report quoted from a report by the
Wisconsin Tax Commission, which stated that the disclosure provisions had been introduced in 1923 but that none of the asserted benefits had yet materialized. According to the Wisconsin report, the published returns were used by credit companies, salespersons, business competitors, and to annoy and harass taxpayers. ${ }^{152}$ The Wisconsin report indicated that disclosure had not resulted in the discovery of unreported income and claimed that it had actually led to more incorrect returns being filed.

No explanation was provided why the number of incorrect returns should have increased or if they did, why that increase should have been attributed to disclosure.

The Wisconsin report was contrary to assertions made by LaFollette some years earlier. He claimed that Wisconsin's disclosure laws revealed that taxpayers had fraudulently underpaid $\$ 9,000,000$ during a period when returns were secret. He claimed that such behavior was eliminated in 1923 when Wisconsin adopted its publicity provisions. "I believe, that the fact that the income-tax returns are public records produces a very different psychology upon the part of the individual taxpayer when he makes out his return, whether it be under a secret provision or whether it be under a provision where it is a matter of public record."153 Nonetheless, the House Report concluded that the pink slips would "greatly aid the racketeers, gangsters, kidnapers, and the criminal element of the country." 154

The repeal of the pink slips could be explained in part by Congressional self interest. One Congressman, recalling the country's earlier experience with disclosure, reminded his colleagues that "when the first income-tax payments were made public ... the names of the Congressmen were the first ones most eagerly published and 
scanned."155 One commentator gave credit for the repeal to the ability of the anti-publicity forces to characterize themselves as defending the middle class. They would, for example, emphasize how embarrassed an unsuccessful businessmen would be at seeing his or her business affairs laid out on the local front page. The specter was raised of creditors cutting off the flow of funds. The Sentinels of the Republic also used small-business imagery that obscured their dependence on wealthy conservatives. ${ }^{156}$

Repeal of disclosure was certainly not a sure thing. As late as February 1935, there was actually little hope for repeal. ${ }^{157}$ Subsequently, the repeal forces quickly and effectively began to assemble a formidable coalition of merchants' associations, chambers of commerce, and other business groups. The Bureau of Internal Revenue and other Treasury officials also supported repeal. Although Secretary of the Treasury Morgenthau refused to endorse repeal, the Treasury was anything but neutral. In addition, Roosevelt's apparent caution, conservatism, and drift in early 1935 made the disclosure law vulnerable. ${ }^{158}$ As the tide turned in favor of repeal, a lastditch amendment in the House to confine publicity to people earning over $\$ 25,000$ a year was easily defeated. ${ }^{159}$ Remarkably, only one month after the pundits had discounted the chances of repeal, it swept Congress. ${ }^{160}$

The pink slip proposal was the last time the issue of access to tax information by the general public was debated by Congress. ${ }^{161}$ Similar to most of the earlier debates, the focus was on individuals and to a lesser extent, on small corporations. The lobbying effort (as exemplified by

the Sentinels of the Republic), the appeal made to the public (invoking the fear of kidnapping, criminal extortion, constant solicitation), the pressure put on Congress (as Representative Bacon said, coming mostly from those of "modest means"), the House Report, and the debate in Congress, all centered on the concerns of individuals and of small corporations. No attempt was made to distinguish those concerns from those of publicly-traded corporations.

Until 1976, the law continued to provide for the 1910 delegation of authority to the Executive branch to open tax returns to inspection upon order of the President and under rules prescribed by the Secretary of

One commentator gave credit for the repeal to the ability of the anti-publicity forces to characterize themselves as defending the middle class. They would, for example, emphasize how embarrassed an unsuccessful businessmen would be at seeing his or her business affairs laid out on the local front page... They also used small-business imagery that obscured their dependence on wealthy conservatives. 
"The stock market crash of 1929...led to an "outcry for full disclosure in all matters corporate and financial."

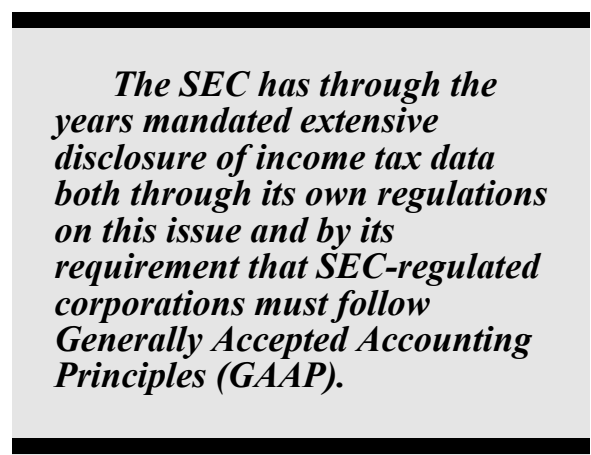

the Treasury and approved by the President. Debate over this provision shifted to governmental access to tax returns by agencies other than the IRS. This debate was marked by a dizzying sequence of policy flips and turns, ${ }^{162}$ with unelected administrators in the Executive branch exercising enormous power: "[T]he story is one of the exercise of discretion granted by a Congress unwilling to define precisely the policy to be followed,"163 concluded a 1975 report to the Senate. The Tax Reform Act of $1976^{164}$ ended the Executive branch's discretion. In the aftermath of the abuses of Watergate, ${ }^{165}$ Congress announced the general rule that "[r]eturns and return information shall be confidential," ${ }^{166}$ except as otherwise authorized.

\section{G. SEC Disclosure: 1933 - Present}

In the late 1920 's and early 1930 's, increasing attention was focussed on the financial reporting practices of large corporations. In a series of articles in the Atlantic Monthly and then in his influential book, Main Street and Wall Street, Harvard economist William Z. Ripley accused large corporations of deceptive and misleading financial reporting. ${ }^{167}$ Following the stock market crash of 1929, which led to an "outcry for full disclosure in all matters corporate and financial," 168 the American Institute of Accountants and the New York Stock Exchange began working together to improve corporate financial reporting. In 1933, the New York Stock Exchange for the first time threatened a listed company (Allied Chemical) with delisting unless it improved its financial disclosures. ${ }^{169}$ In the same year, the Securities Act of 1933 was enacted, ${ }^{170}$ which required "full and fair disclosure" in the prospectuses that accompany the interstate issuance of securities. ${ }^{171}$ This was immediately followed by the Securities Exchange Act of 1934, ${ }^{172}$ which created the Securities and Exchange Commission (SEC) to administer both the 1933 and 1934 Acts. The 1934 Act also required the filing of periodic reports by companies whose securities were listed on the national exchanges.

A primary function of the SEC was seen to be the regulation of disclosure and measurement standards, ${ }^{173}$ based largely upon the belief that the securities markets' failure of the 1930's resulted from inadequate disclosure and an excessive number of measurement methods used by public companies. ${ }^{174}$ For this reason, the Securities Act of 1933 is often referred to as the "truth in securities law."175

The SEC has through the years mandated extensive disclosure of income tax data both through its own regulations on this issue and by its requirement that SEC-regulated corporations must follow Generally Accepted Accounting Principles (GAAP), as established by the appropriate accounting bodies (currently the Financial Accounting Standards Board (FASB)). ${ }^{176}$ Other countries have adopted similar rules. ${ }^{177}$

Taxes as a significant item of expense have been included in the financial statements of most large corporations, at least since the postDepression era. There has long been a consensus that income taxes should be disclosed; more controversial has been the treatment of interperiod allocations, that is, how to treat the tax implications of differences in timing of the recognition of income for book and tax purposes. Although these technical rules have continued to be refined, neither the SEC nor the authoritative accounting standards bodies have ever found the 
arguments against disclosure of income taxes to be persuasive.

In 1973, the SEC adopted the current rules on the disclosure of income taxes. ${ }^{178}$ The 1973 arguments made by opponents of the SEC's position are similar to those that have been raised during

the current debates regarding statelevel disclosure and thus merit mention. In response to comments that the 1973 proposals would violate the confidentiality of federal income tax information and provide valuable data to competitors, the SEC observed that the full and fair disclosure of material information is a basic part of the Securities Act of 1933 and the Securities Act Exchange of 1934. Each Act provides that registration statements must contain, in addition to other information specified, such information "as the Commission may by rules or regulations require as being necessary or appropriate in the public interest or for the protection of investors." The SEC believed that its 1973 rules were consistent with this authority. The SEC also noted that opponents did not provide any specific examples of how the detailed reporting of income taxes would help com-petitors, but in any event it concluded that the needs of present and potential investors were best served by providing such information, notwithstanding there may be an increased risk of adverse consequences at the hands of competitors.

The 1973 changes, requiring detailed information on federal income taxes and aggregate data on state income taxes, is part of a panoply of financial data that the SEC requires to be disclosed. Such information is presented in Form 10$\mathrm{K}$, which publicly-traded corporations must annually file with the Securities and Exchange Commission. ${ }^{179}$ The $10-\mathrm{K}^{180}$ must be sent to stockholders of record or beneficial owners on request without charge. ${ }^{181}$ Some corporations also make it available to public on request. It is also accessible on the SEC's electronic data gathering analysis and retrieval system (EDGAR), as well as through commonly used computer data bases such as LEXIS and Compustat. EDGAR will soon be available on Internet. ${ }^{182}$

Form 10-K consists of four general parts, only one of which deals with federal income taxes. The first contains detailed disclosures relating to business, properties, legal proceedings and submission of matters to a vote of security holders. The second part consists of market price data for the company's common stock, a
Although technical rules have continued to be refined, neither the SEC nor the authoritative accounting standards bodies have ever found the arguments against disclosure of income taxes to be persuasive.

In 1973, the SEC noted that opponents did not provide any specific examples of how the detailed reporting of income taxes would help competitors, but in any event it concluded that the needs of present and potential investors were best served by providing such information. 
Working with SEC Forms 10-K, annual reports, and related information, Citizens for Tax Justice (CTJ) was able to compare the amount of federal income taxes paid by many of the nation's largest corporations with the amount of their income. summary of financial data appropriate for trend analysis, three years of audited financial statements and management's discussion and analysis of the issuer's financial condition. The third part consists of the traditional proxy disclosure information relating to directors and executive officers, executive compensation, beneficial ownership of securities and certain relationships and related transactions. The fourth contains the required financial statements. $^{183}$ The federal tax information that must be disclosed includes the following: ${ }^{184}$

(1) current aggregate income taxes paid to all governments: income taxes paid to the United States, foreign jurisdictions, and state and local governments must be identified separately;

(2) deferred tax expenses disaggregated by U.S. government, state and local governments, and foreign jurisdictions. Deferred tax expenses represent those taxes that the corporation would have incurred if the timing and recognition of revenue and expenses for financial accounting purposes were identical to the timing and recognition of revenue and expenses for federal income tax purposes. A corporation must identify by amount each major item that contributes to the difference between actual and deferred tax expenses, such as depreciation;

(3) tax effects of net operating losses;

(4) amount of investment tax credit;

(5) expected U.S. income tax expense. This expense is the amount of tax that the corporation would pay if all of its book income were subject to the highest statutory federal corporate income tax rate;

(6) actual U.S. income tax expense as a percentage of its book income;
(7) the identity and amount of each major item responsible for any differences between expected and actual income tax expense.

There are numerous other reports that also must be filed with the SEC. ${ }^{185}$

\section{H. Citizens for Tax Justice and the Use of SEC-Required Disclosure for Tax Policy Analysis}

Working with SEC Forms 10-K, annual reports, and related information, Citizens for Tax Justice (CTJ) was able to compare the amount of federal income taxes paid by many of the nation's largest corporations with the amount of their income. ${ }^{186}$ Through a series of reports in the 1980s, CTJ was able to show that

many of the most profitable corporations in the United States were paying little or no corporate income tax. Incredibly, some companies were receiving subsidies from the federal government in the form of tax 
rebates while making billions of dollars in profits. Thus, some companies actually had negative tax rates.

CTJ found that the federal corporate income tax policies of the early 1980 s - intended to stimulate increased investment - had became a device for corporations to "shelter" their income in misplaced investments and considerably reduce or eliminate their tax liability. In fact, in a report issued just before the 1986 Tax Reform Act, CTJ found that more than half of the 250 most profitable corporations in the US that were surveyed enjoyed at least one federal tax-free year between 1981 and 1985.

For example, CTJ found that Boeing corporation made close to $\$ 3$ billion in profits from 1981 to 1985 and received rebates totaling more than \$245 million from the government - a net tax rate over those years of negative 8.3 percent. Likewise, the federal government gave Dow Chemical Corporation rebates over that period totalling $\$ 200$ million on \$771 million in profits - a negative 25.9 percent rate.

Many of the provisions that gave these companies such large tax benefits had been adopted in the name of economic growth. But a detailed analysis of 41 companies that paid no federal income tax at all from 1981 to 1984 found that they reduced their aggregate capital spending by 4 percent during that period and cut their total number of employees by 6 percent over the same period. Yet these corporations received those huge tax breaks ostensibly to encourage growth in capital spending and job creation. In contrast, the 43 highest-taxed companies in CTJ's 1981-84 analysis boosted their capital spending by 21 percent and added 4 percent to their workforce.

Another flaw in the federal corporate income tax revealed by CTJ was the unequal treatment of direct competitors. A 1984 study, for example, revealed that General Electric obtained $\$ 283$ million in tax rebates while earning profits of $\$ 6.5$ billion in 1981-83. At the other end of the spectrum, one of the highest taxed corporations in the survey also was a major manufacturer of appliances. Whirlpool Corporation paid 45.6 percent of its profits in federal income taxes. Thus, direct competitors had significant differences in their after-tax rates of return because of the tax code.

The publication of this type of information by CTJ had a staggering impact. Although information on the aggregate decline and disparities in federal corporate income taxes had been available previously, none of it had the force of CTJ's documentation.

When the CTJ studies were published, both conservatives and liberals were outraged. Conservative columnist James Kilpatrick, for example, complained about corporate welfare to Senator Robert Byrd on national television, saying that a mother of three, who earned

In a report issued just before the 1986 Tax Reform Act, CTJ found that more than half of the 250 most profitable corporations in the US that were surveyed enjoyed at least one federal tax-free year between 1981 and 1985.
When the CTJ studies were published, both conservatives and liberals were outraged. Conservative columnist James Kilpatrick, for example, complained about corporate welfare to Senator Robert Byrd on national television, saying that a mother of three, who earned \$12,000, paid more in taxes than Boeing, GE, DuPont, and Texaco, combined. 
Because the 1986 federal tax reform closed business tax loopholes, Congress and President were able to reduce the top corporate income tax rate from 46 percent to 34 percent-and still increase the revenue from the corporate income tax substantially.

By 1988, only seven of the 250 corporations that CTJ had earlier surveyed were now able to avoid federal income taxes entirely.
$\$ 12,000$, paid more in taxes than Boeing, GE, DuPont, and Texaco, combined.

Largely because of this public outrage, and the very real policy problems exposed by CTJ's work, federal tax reform in 1986 included a strengthened alternative minimum tax. Other significant changes repealed the investment tax credit, tightened the "completed contract accounting rules" that had eliminated taxes for defense contractors, and restricted other corporate tax shelters. Because of the added revenue from these changes, Congress and the President were able to reduce the top corporate income tax rate from 46 percent to 34 percent - and still increase the revenue from the corporate income tax substantially.

By 1988 , only seven of the 250 corporations that CTJ had earlier surveyed were now able to avoid federal income taxes entirely. Only forty-five companies were able to bring their effective tax rate below 10 percent. In contrast, 113 of these same companies had paid less than 10 percent of their profits in taxes over the full 1981-1985 period. All but two of the forty-one corporations that paid no tax at all over the 1981 to 1985 period had to pay at least some federal income tax in 1988. The combined tax rate for these 41 companies, which was a negative 4.3 percent from 1981 to 1985 , increased to 27.9 percent of their profits in 1988.

In addition, tax reform brought a more level playing field for $\mathrm{GE}$ and Whirlpool. In 1988, GE paid 21 percent of its profits in taxes; Whirlpool paid 27 percent. The gap between their effective tax rates narrowed from 50 percentage points to only six.

Although opponents of tax reform argued that business investment would decline as a result of changes in the corporate tax structure and predicted imminent economic collapse, just the opposite occurred. There was actually a strong surge of business investment. Real business investment in industrial equipment, which rose by a minuscule 0.1 percent annually from 1981 to 1986 (the years when corporate incentives for investment were greatest), increased by an annual 4.0 percent during the three years following the 1986 changes.

From 1986 to 1989, real business fixed investment grew at an annual rate of 2.7 percent, appreciably more than the 1.9 percent rate of growth over the previous five years.

\section{Summary}

Since the repeal of the pink slip provisions in 1934, Congress has not revisited the issue of public access to federal tax returns. The semi-hysterical atmosphere in which the pink slips were debated proved to be the death knell for public access to both individual and corporate tax returns. In a sense, subsequent events have reduced the need for public access to federal corporate income tax returns. The SEC has essentially preempted the issue by mandating the disclosure of extensive data by publiclytraded corporations. ${ }^{187}$ Because of the cornucopia of data already in the public domain, it is easy to understand why there has been no further debate at the federal level about public access to corporate returns. Our increased concern for individuals' rights to privacy also makes it easy to understand why there has been no post-1934 debate over access to individual tax returns. It is unthinkable in 1993 for proposals like the pink slip returns for individuals to be taken seriously. ${ }^{188}$

The history of disclosure at the federal level indicates that on the occasions when Congress focused 
on the differences between corporations and individuals, it tended to opt for more disclosure in the case of corporations. Even today, the fact that a $1 \%$ shareholder can inspect the tax return of his or her corporation (although a shareholder cannot disclose anything obtained from the inspection), ${ }^{189}$ indicates that corporations are treated as having less legitimate claims to privacy than individuals. ${ }^{190}$ What is surprising in reviewing the history of the federal debate is the inordinate amount of attention that the Progressives placed on obtaining the income tax returns of individuals to the neglect of corporations. If the Progressives and other supporters of disclosure had more carefully distinguished between corporations and individuals and proposed separate and independent laws governing access to the tax returns of each, they might have been more successful in protecting the victory they won in 1924 and perhaps salvaged the pink slips for corporations. No one apparently on either side of the debate went to great lengths to distinguish the different issues involved in corporate disclosure from that of access to individual returns. Having chosen to pitch their battle over access to individual returns, supporters of disclosure gave up an opportunity to achieve cor-porate disclosure. But as was seen, LaFollette and the Pro-gressives, as well other early advocates of disclosure, were eventually vindicated by the SEC's actions over the last 60 years.

The use of SEC-mandated disclosure by CTJ to transform the inaccessible and arcane world of corporate taxation into a cornerstone of the 1986 Tax Reform Act has not been lost on state tax reformers. With the SEC effectively resolving the issue of federal tax disclosure, debate has shifted to the state level and to the disclosure of state corporate income taxes.
The SEC has essentially preempted the issue by mandating the disclosure of extensive data by publicly-traded corporations. Because of the cornucopia of data already in the public domain, it is easy to understand why there has been no further debate at the federal level about public access to corporate returns.
The history of disclosure at the federal level indicates that on the occasions when Congress focused on the differences between corporations and individuals, it tended to opt for more disclosure in the case of corporations. 


\section{Disclosure at the State Level}

In 1992, due to the efforts of the Tax Equity Alliance for Massachusetts (TEAM), Massachusetts voters approved a ballot question calling for extensive corporate tax disclosure. The law applied to all publicly-traded corporations that already disclose information about their federal tax expenses and their state corporate tax expenses on a 50state aggregate basis, all banks, and virtually all insurance companies doing business in the state.
The effective use of the federal disclosure laws in the mid-1980s motivated state legislators and tax reformers to consider similar laws at the state level. Their interest was heightened by increasing concern about state revenue shortfalls, brought about by a number of factors, including reductions in federal aid, the recession and statutorily-mandated limitations on revenue-raising at the local or state levels. In addition, several states adopted an array of corporate tax credits and other tax expenditures in an effort to stimulate their recessionplagued economies.

In light of the states' budget problems, questions were raised about whether corporations were paying their "fair share" of the cost of public services. And, specifically, the adoption of new corporate tax incentives in the face of looming deficits raised serious concerns about whether these expenditures were achieving their intended goals. It soon became obvious that none of these questions could be answered without more information about how much specific, large businesses were paying in state taxes.

At the state level, only Wisconsin, the home of both the LaFollettes, has long had a history of income tax disclosure, but until recently its law went unnoticed by other states. Perhaps this neglect was understandable since only lately have Wisconsin tax reformers used the disclosure law effectively. Three other states have adopted disclosure laws within the past few years, the most controversial being Massachusetts. This Section reviews these states' experiences with disclosure.

\section{A. Massachusetts}

In 1992, due to the efforts of the
Tax Equity Alliance for Massachusetts (TEAM), Massachusetts voters approved a ballot question calling for extensive corporate tax disclosure. The law applied to all publicly-traded corporations that already disclose information about their federal tax expenses and their state corporate tax expenses on a 50-state aggregate basis, all banks, and virtually all insurance companies, doing business in the state. These corporations were required to file annual reports with the Secretary of State, listing specific items from their state excise (income) tax returns, which would be available for public inspection upon request.

The ballot question called for a panoply of information to be disclosed: ${ }^{191}$ gross profit; taxable Massachusetts tangible property; taxable net worth; gross receipts or sales; net income; total net taxable income; income subject to apportionment; income taxable in Massachusetts; total net and gross direct premiums in or allocable to Massachusetts; taxable premiums; gross investment income; Massachusetts taxable investment income; net underwriting profit; admitted assets; total adjusted taxable income; each deduction, exemption, credit, offset, adjustment, or credit to carry over that reduces income subject to taxation or otherwise affects tax liability; the percentage used, if any, to establish what portion of

total net taxable income is apportioned to Massachusetts; total Massachusetts excise or tax due; any excess tax credits or credits subject to carryover to future years; and net income according to a company's books on its federal return. A company could request permission to attach additional information. Entities filing a consolidated return 
had to list all the entities that were consolidated.

A coalition of business groups aggressively opposed the ballot question. Two months before successful passage of the ballot question, TEAM, the business community, and legislative leaders reached a political compromise and agreed to adopt a less extensive form of disclosure that would take effect at the end of 1993, regardless of the outcome of the ballot vote. Ultimately, both houses of the Legislature passed this compromise and Governor Weld signed it into law. ${ }^{192}$ As part of this compromise, a Special Commission on Business Tax Policy was created to study Massachusetts business taxes. ${ }^{193}$

Although the same taxpayers are subject to the law actually enacted, the amount of information required to be disclosed was reduced. Specifically, businesses are currently required to disclose the following:

(1) corporate name;

(2) address of principal office;

(3) Massachusetts taxable income;

(4) total Massachusetts excise tax due;

(5) non-income excise tax due;

(6) gross receipts or sales;

(7) either gross profit or credit carry overs to future years;

income subject to apportionment. ${ }^{194}$

The items covered are slightly different in the case of banks and insurance companies, in recognition of the different bases on which they are taxed. ${ }^{195}$ Corporations filing a combined return must report the names and addresses of all the corporations that are combined.

The Secretary of State must make available a list of all taxpayers that are subject to disclosure. The first reports under the new law are due December 31, 1993, based on the taxpayer's most recently filed Massachusetts tax return.

The enacted bill continues to provide corporations covered by the disclosure requirement with the opportunity to provide the Secretary of State additional information as part of their annual disclosure reports. This provision was included to provide corporations with an opportunity to provide a fuller understanding of the financial and tax information being disclosed. ${ }^{196}$ The Secretary of State has to make all of the above information available for public inspection.

The Commissioner of Revenue is required to publish an aggregate

A coalition of business groups aggressively opposed the ballot question. Two months before successful passage of the ballot question, TEAM and legislative leaders reached a political compromise and agreed to adopt a less extensive form of disclosure that would take effect at the end of 1993, regardless of the outcome of the ballot vote.

The Massachusetts law allows corporations to provide additional information as part of their annual disclosure reports in order to provide a fuller picture of their financial and tax situation. 
Under legislation passed in 1991, the West Virginia Tax Commissioner must publish in the State Register the name and address of every taxpayer, whether a corporation or individual, receiving any of eleven specified tax credits, and the amount, by dollar category, of each such credit received. statistical report of the taxes collected from corporations and other businesses, as well as many of the tax credits, deductions, exemptions, and exclusions claimed under Massachusetts law. The report has to disaggregate data by industry and categories of firm size.

Notwithstanding the political compromise that led to the thinned down disclosure provisions, more changes may still occur. In July, 1993, the Special Commission on Business Tax Policy voted seven to five to recommend legislation that would replace the existing tax disclosure law with a system of coded disclosure under which corporations would be identified only with a number. It was further recommended that the coded disclosure indicate the amount of tax credits claimed by a corporation. Finally, it was recommended that each corporate filer, which is not part of a combined return, should enter on its tax disclosure report a numerical code indicating the multicorporate entity, if any, with which it is affiliated. ${ }^{197}$

In a controversial parliamentary procedure of dubious legality, ${ }^{198}$ the Massachusetts Senate adopted a version of the Majority Report. ${ }^{199}$ In a significant deviation from the Majority Report, however, the Senate bill provided that the number assigned to each corporation as part of the anonymous disclosure must be changed from year to year. Moreover, there is no provision for identifying affiliated corporations. ${ }^{200}$

\section{B. West Virginia}

Under legislation passed in 1991, the West Virginia Tax Commissioner must publish in the State Register the name and address of every taxpayer, whether a corporation or individual, receiving any of the following twelve tax credits, and the amount, by dollar category, of each such credit received:
Business Investment and Jobs Expansion Credit;

Industrial Expansion and

Revitalization Credit;

Research and Development Credit;

Residential Housing Development Credit;

Management Information Services Facility;

Coal Conversion Facility Credit;

Coal Loading Facility Credit;

Excess Generation of Electricity from Coal Credit;

Low Income Electric Utility Credit;

Low Income Gas Utility Credit;

Low Income Telephone Utility Credit; and

Capital Company Credit.

The following dollar categories are to be used in the required disclosure report:

Not more than $\$ 50,000$;

More than $\$ 50,000$, but not more than $\$ 100,000$;

More than $\$ 100,000$, but not more than $\$ 250,000$;

More than $\$ 250,000$, but not more than $\$ 500,000$;

More than $\$ 500,000$, but not more than $\$ 1,000,000$; and

More than \$1,000,000. 
The statutorily-stated purpose behind the legislation was to recognize "the citizens' right to accountable and efficient state government." 201 The Department of Revenue will issue its first report in December, 1993.

Support for the disclosure legislation arose after publication of a report by the West Virginia Department of Tax and Revenue. ${ }^{202}$ This study showed that only a small number of taxpayers benefit from the state's investment and jobs expansion tax credit (known as the supercredit). ${ }^{203}$ As of 1990, approximately 200 taxpayers have utilized the supercredit, representing less than $1 \%$ of total corporate net income filers. About 50 taxpayers claimed credits in excess of $\$ 100,000$ annually. ${ }^{204}$ The supercredit is used primarily by industries that have been reducing employment, especially the coal industry, which between 1985 and 1988 received nearly $90 \%$ of the credit. According to the study, the costs of the supercredit have escalated. In 1985, the supercredit cost $\$ 287,000$, but by fiscal year 1991, it was expected to cost the State $\$ 60$ million. ${ }^{205}$ The supercredit effectively eliminates all West Virginia tax liabilities for a thirteen year period for most qualifying taxpayers.

The disclosure legislation was resisted on the grounds that it would impair West Virginia's business climate. Businesses did not lobby strenuously against it, however, out of fear that the Legislature might actually reduce the supercredit. ${ }^{206}$ Although they were not successful at stopping the legislation, businesses won a major concession in the way the categories used for reporting purposes were to be designated. The last category, the "more than $\$ 1,000,000$," was favored by large companies "eager to conceal their annual tax credits of over $\$ 10,000,000 . " 207$
In 1991, Arkansas authorized the disclosure by name of taxpayer-including both individuals and corporations--of the amount of any tax credit, tax rebate, tax discount, or commission for the collection of a tax received under the following provisions:

$2 \%$ discount for prompt payment of the sales tax;

Manufacturer's investment sales and use tax credit;

Steel mill tax incentives;

Motor fuel shrinkage allowance;

Arkansas Enterprise Zone Act;

Commission for sale of stamps for cigarettes in the collection of cigarette taxes;

Motion Picture Incentive Act; Credit on severance tax of oil producers;

Credit on severance tax of gas producers;

Refund of motor fuel tax for agricultural purposes;

Refund of motor fuel tax by municipal buses;

Refund of distillate special fuel tax to interstate users;

Credit against severance tax for discovery of commercial oil pool; and,

Native wine credit. ${ }^{208}$
The statutorily-stated purpose behind the legislation was to recognize "the citizens' right to accountable and efficient state government."

The disclosure legislation was resisted on the grounds that it would impair West Virginia's business climate. Businesses did not lobby strenuously against it, however, out of fear that the Legislature might actually reduce the supercredit.

\section{Arkansas}


Issues of tax reform did not play a dominant role in the Arkansas discussions; the disclosure issue was basically argued in terms of openness in government.
The Arkansas law also provides that the disclosure requirement will cover any tax incentive program enacted after January 1, 1991, which provide a tax credit, tax rebate, tax discount, or commission for the collection of a tax, with the exception of any such benefits under the state's income tax laws. ${ }^{209}$ Although the law is drafted in terms of "disclosing" the name of the taxpayer and the amount of the tax benefit, the Arkansas Department of Finance and Administration is not required to publish any type of report or to analyze the data covered by disclosure. ${ }^{210}$ Rather, a person must request the information from the Director of Taxation. The Director must notify the taxpayer that information has been requested. ${ }^{211}$ The taxpayer has up to seven days to challenge the release on the grounds that it would give an advantage to "competitors or bidders," or that it is in some other way prohibited. Apparently, only a few businesses have opposed the release of information, although the seven day period may discourage challenges.

One group of taxpayers that successfully enjoined the Director from disclosing information to an out-of-state competitor involved wholesale tobacco distributors. They successfully argued in the lower court that disclosing the amount of commissions received by cigarette wholesalers in Arkansas for the sale of stamps for cigarettes and the collection of cigarette taxes received by a tobacco wholesale grocery could be used to determine total cigarette sales. In conjunction with other available data, this disclosure would give competitors an advantage in marketing and selling cigarettes. The decision is currently under appeal. $^{212}$

The disclosure legislation in Arkansas has a unique background, with its roots in that state's Freedom of Information Act (FOIA). In 1986, the Arkansas Supreme Court ruled that motor fuel tax records were subject to disclosure under Arkansas'
FOIA--one of the broadest in the country. ${ }^{213}$ To overrule that case, key oil dealers in the Arkansas Legislature sponsored a 1987 amendment that insured the confidentiality of all tax returns and tax reports. The Arkansas Society of Professional Journalists fought this amendment unsuccessfully in 1987 but their persistent efforts led to the 1991 disclosure law. ${ }^{214}$

Issues of tax reform did not play a dominant role in the Arkansas discussions; the disclosure issue was basically argued in terms of openness in government. ${ }^{215}$ Because income tax data were never within the purview of the FOIA, no one, during the debates over the 1991 law, suggested that disclosure be extended to that tax. Moreover, no one suggested that information covered by the 1991 law be published by the state. Under the FOIA, information would have been available only to the person making the request, and the 1991 law, intended to mirror the status quo ante under the FOIA, adopts a similar position. 


\section{Wisconsin}

Wisconsin's first income tax law, enacted in 1911, prohibited tax administrators from disclosing income tax information under penalty of fine or imprison-ment. ${ }^{216}$ In 1919, the statute was amended to permit disclosure of income tax information to property tax assessors "as may be necessary in the proper performance of [their] duties." 217 In 1923, the nondisclosure provisions were repealed, ${ }^{218}$ partially in response to concerns that corporations were using the secrecy provisions as a shield for tax evasion. ${ }^{29}$ From 1923 until 1953, the actual Wisconsin income tax return was public information, ${ }^{220}$ despite strong opposition from business organizations ${ }^{221}$ and attempts by the Legislature to restore the secrecy provisions. ${ }^{222}$ In 1953, anti-disclosure advocates succeeded in amending the law to deny public access to the actual tax returns but to permit disclosure only of net taxes paid. ${ }^{223}$

In Wisconsin, the public has access to the amount of income tax paid by both individuals and corporations. The State's Department of Revenue must furnish to any Wisconsin resident who requests it the net income tax, franchise tax, or gift tax reported in any year by any individual or corporation. ${ }^{224}$ The following conditions must be satisfied:

$$
\begin{aligned}
& \text { individuals seeking the } \\
& \text { information must be } \\
& \text { Wisconsin residents; }{ }^{225}
\end{aligned}
$$

persons must pay a fee of $\$ 4$ per return from which information is sought;

persons must prove their identity and sign a statement disclosing their addresses and reasons for making the request. ${ }^{226}$ This information is sent to the individual or corporation whose tax information is being requested. $^{227}$

The Wisconsin Action Coalition (WAC) used this provision of Wisconsin law to compile a list of major corporations doing business in Wisconsin that had not paid state income taxes. WAC's work played a major role in the passage by the Legislature, on two different occasions, of legislation establishing to pass twice a new corporate minimum income tax. In both cases, the Governor successfully vetoed the proposed tax. ${ }^{228}$
Wisconsin's Department of Revenue must furnish to any state resident who requests it the net income tax, franchise tax, or gift tax reported in any year by any individual or corporation. 
The Massachusetts law has the potential for being catalytic because of the intense scrutiny now being given to the issue by all sides in Massachusetts. Its future, however, is problematic due to the vitriolic opposition of elements of the business community, the recent recommendation of the Special Commission on Business Policy and the vote of the Massachusetts Senate.

\section{E. Lessons to Date}

What lessons can be drawn from the experience to date in other states? As the efforts of Citizens for Tax Justice (CTJ) have demonstrated, federal tax information in the public domain can be used constructively to focus attention on the esoteric and sometimes intimidating world of corporate taxation. What little experience exists at the state level is consistent with CTJ's federal success. In Wisconsin, for example, the Wisconsin Action Coalition was able to use publicly-available state data to generate an informed discussion of the need for a corporate minimum tax. The result of this discussion, to date, has been the passage by the Wisconsin Legislature, on two occasions, of bills establishing a corporate minimum tax and the veto of both bills by Governor Tommy Thompson.

The laws in Arkansas (1991), West Virginia (1991), and Massachusetts (1992) are so newly enacted that no information is yet available on their use or impact. The first disclosures under the Massachusetts and West Virginia legislation are scheduled for December 1993. The Arkansas disclosure requirements were not motivated by tax reform considerations; whether it will be used for this purpose may depend on the newspapers and other media that advocated for that state's law. The West Virginia legislation, which deals only with credits, suffers because the categories for presenting the data are not detailed enough to be very useful. ${ }^{229}$ The Massachusetts law has the potential for being catalytic because of the intense scrutiny now being given to the issue by all sides in Massachusetts. Its future, however, is problematic due to the vitriolic opposition of elements of the business community, the recent recommendation of the Special Commission on Business Policy and the vote of the Massachusetts Senate. ${ }^{230}$ 


\section{Evaluating the Case for State-Level Tax Disclosure by Publicly-Traded Corporations}

This Section evaluates the arguments on behalf of state-level disclosure. The arguments assume that disclosure would apply to publicly-traded corporations, ${ }^{231}$ which are already subject to the extensive disclosure requirements of the SEC. These corporations not only reveal extensive financial data about their activities, but they also disclose the amount of their federal income taxes and the aggregate amount of their state income taxes. ${ }^{232}$ State-level disclosure would require that these corporations disaggregate information that they already make public, albeit in aggregate form.

This Section also considers the arguments against disclosure and concludes that the arguments in favor easily outweigh the arguments against. Accordingly, the next Section discusses some of the policy and technical issues that need to be resolved in formulating a state-level disclosure law.

\section{A. Firm-Specific Disclosure is Necessary for Informed Tax Policy}

Residents, businesses, and public officials in every state have an obvious interest in the workings of their states' corporate income tax laws. If for no other reason, significant sums of money are involved -- both in the amount of corporate taxes collected and in the amount forgiven through tax expenditures. ${ }^{233}$

On a more fundamental level, the issue of how a state taxes, or exempts from tax, corporate activity raises fundamental value judgments about how the costs of

government should be distributed. Both large-scale corporate tax avoidance and inefficient tax expenditures mean that a state must have a higher than necessary corporate tax rate, rely more heavily on other taxes--with different incidence patterns, or reduce spending for important capital or operating purposes.

In addition to the question of how taxes are distributed between corporations and individuals, another significant issue is how the corporate tax burden is distributed among corporations in the same industry and among different industries. At the federal level, at least prior to the 1986 tax reforms, corporate tax incentives were shown to benefit some industries and firms disproportionately. ${ }^{234}$

The federal corporate income tax was characterized by striking interand intra-industry disparities in effective corporate tax rates. Similar state tax differentials undoubtedly exist. In many states,

Residents, businesses, and public officials in every state have an obvious interest in the workings of their states' corporate income tax law. If for no other reason, significant sums of money are involved-both in the amount of corporate taxes collected and in the amount forgiven through tax expenditures.
The federal corporate income tax was characterized by striking inter- and intra-industry disparities in effective corporate tax rates. Similar state tax differentials undoubtedly exist. 
Disclosure allows the public to evaluate more effectively corporate claims that they are straining under an excessive tax burden. the corporate tax is replete with provisions that distinguish between small and large corporations, in-state corporations and out-of-state corporations, capital-intensive corporations and labor-intensive corporations, and corporations that sell out-of-state and those that sell within the state. ${ }^{235}$ The level playing field that was a goal of the 1986 federal tax reforms is still a fantasy in most states.

Tax credits and other incentives or subsidies represent another feature of the corporate income tax that is of major concern. To evaluate whether tax incentives serve their ostensible purposes, researchers must know, at the very least, which corporations received what types of incentives and in what amounts. Only then can it be determined whether the benefits to society of these incentives justify the forgone revenue, and whether such incentives need to be enhanced, reduced, or redirected.

Firm-specific data facilitate consideration of a full range of issues surrounding corporate tax policies. Disclosure facilitates informed and critical evaluation of the distribution of tax burdens among corporations and of corporate requests for tax relief--requests that may be underscored

by express or implied threats to abandon a state for a more favorable tax climate. Disclosure allows the public to evaluate more effectively corporate claims that they are straining under an excessive tax burden. And, disclosure would discourage corporations from misleading legislators and the media by taking public positions that are inconsistent with the facts.

Without firm-specific data, it is not possible to do the type of analysis, known as microsimulation, which provides the most accurate picture of the impact of tax policy changes. Only with microsimulation is it possible to consider the interrelationship of different provisions of the tax code. The use of aggregate data can result in significant over or underestimates of the impact of policy changes, particularly when more than one change is being made, which is usually the case when tax laws are being revised.

Microsimulation is an increasingly important tool within sophisticated governmental tax policy units and a growing number of consulting firms are developing microsimulation models of particular state taxes. State agencies and other interested parties realize that such models are important if they are to participate in tax policymaking in an informed manner.

Microsimulations evaluate the impact of particular changes in the tax law on both the yield of the tax involved and on the distribution of the burden among taxpayers. For example, a corporate income tax micro-simulation model would allow the user to determine how much of a reduction in the rate of a particular tax could be financed by eliminating a particular credit without reducing the overall yield of the tax. A microsimulation model can also determine how such

a revenue-neutral change would redistribute the burden of the tax involved among industries or among firms in different size categories; how many firms are likely to pay more and how many are likely to pay less; and, the number of such increases and decreases that are likely to result in particular size categories.

A microsimulation model for a particular tax involves the interaction of two key components, both of which must be carefully developed and maintained. The first component is a computer model or simulation of the tax. Similar to the PC software that is now widely available for the computation of the federal personal income tax, this component involves programming the model to compute the tax liability of a particular firm or individual. This programming must 
account for all the various options and elections the law allows and be intricate enough to capture all the nuances and subtleties that are characteristic of tax planning. The difference between this component of a microsimulation model and the software sold for tax preparation purposes is that the former must be designed to provide the user with the ability to modify different aspects of the rules (e.g., changes in the apportionment factor, changes in the rules for combined reporting, altering the availability, size, or nature of various deductions, exemptions, or credits) in order to determine the impact of policy options on the tax liability of a taxpayer with a particular mix of income, deductions, filing status, etc.

The second component is a data base consisting of either the universe of the taxpayers subject to the tax or a stratified sample of actual taxpayers. In the case of microsimulation models for the personal income tax, the typical data base is drawn from a statistically valid sample of tax returns, with the identities of the taxpayers protected for privacy reasons, and with weightings attached to each file based on the total number of taxpayers for whom this sample file is representative. Some state personal income tax simulation models use samples drawn from state tax returns, while others use a sample of the federal tax returns filed by residents of the state involved.

For the corporate income tax, no comparable data base is readily available. Because of the relatively small number of corporate income taxpayers compared to personal income taxpayers, and the relatively small number of firms that represent the bulk of a state's corporate tax revenues, it is not possible to take a sample of returns that is statistically valid without running the risk of revealing the identity of individual firms. Consequently, the data necessary for a corporate microsimulation model are not available, under current law, to parties outside state revenue departments. This significantly limits the ability of other interested organizations to participate in debates over corporate tax policy in the most informed manner possible. Only with firm-specific corporate tax disclosure can this important tool be used most effectively to enhance
Consequently, the data necessary for a corporate microsimulation model is not available, under current law, to parties outside state revenue departments. Only with firmspecific corporate tax disclosure, can this important tool be used most effectively to enhance openness and democracy in the tax legislative process. 
There are other areas where firm-specific data is needed rather than aggregate data. For example, it is virtually impossible based only on statistical aggregates to evaluate the claims of various corporations for tax relief or to verify other tax-related information that corporations might provide in their lobbying efforts.
If, for example, a few of the largest, most profitable corporations in a state pay no (or only a minimum) income tax, such information is highly relevant from a policy perspective but might be lost if buried in an aggregate. openness and accountability in the tax legislative process.

An additional constraint exists in developing a valid data base for state corporate microsimulation models. While a state personal income tax microsimulation model can be constructed with a sample of federal tax returns filed by residents of the state involved, this would not be possible with regard to the corporate income tax.

Unlike a state corporate income tax, states tax their residents on their worldwide income. A state sample built on federal returns can be derived for the personal income tax because individuals who file federal returns are considered to be residing in the states indicated in their mailing addresses. Their worldwide income can be determined from their federal income (although some adjustments are typically necessary.) By contrast, states tax corporations on an apportioned share of their income. Where a corporation is resident (i.e., incorporated) is much less important than in the case of individuals. Moreover, the amount of income that a corporation reports to a state cannot be determined from the federal return. ${ }^{236}$ State-level corporate disclosure, such as that enacted last year in Massachusetts, would allow for the development of an effective corporate microsimulation model at the statelevel.

In addition to facilitating the use of micro-simulation, there are other areas where firm-specific data are needed. For example, it is virtually impossible based only on statistical aggregates to evaluate the claims of various corporations for tax relief or to verify other tax-related information that corporations might provide in their lobbying efforts. Moreover, it is difficult to evaluate the worth of various tax incentives without knowing the identity of the beneficiaries. Indeed, the only way to do a meaningful cost-benefit analysis of a provision like the investment tax credit is to identify the major beneficiaries and do longitudinal studies using other sources of data, such as employment and investment data.

Disclosure eliminates one of the subtle, but serious defects with the use of aggregate data. All too often, what is of interest to researchers are the "outliers." For example, a 1982 study of the New York investment and employment tax credits indicated that two corporations received nearly forty percent of all of the credits allowed--\$56.8 million. ${ }^{237}$ Yet, on an aggregate basis, the average credit claimed was $\$ 16,423$ and half of the claimants received credits of less than $\$ 1,172$. Clearly, statistical aggregates can simply hide much of value in evaluating a state tax system. If, for example, a few of the largest, most profitable corporations in a state pay no (or only a minimum) income tax, such information is highly relevant from a policy perspective but might be lost if buried in an aggregate. ${ }^{238}$

Moreover, firm-specific information on gross receipts, gross sales, or gross profits is essential in attempting to pinpoint the use of transfer pricing to minimize tax liabilities. For example, an analysis of similar firms in the same industry might reveal differing ratios of taxto-gross receipts. Knowing the identity of the corporations involved can help identify which ones are part of multicorporate families that might be reducing their state taxes through intercorporate transfers. A correlation between low ratios of taxto-gross receipts and transactions among related corporations merits further attention as a possible situation involving transfer pricing abuse. $^{239}$

In addition, publishing statistical data without identifying the taxpayers involved inevitably limits its use by researchers. Statistical information can be presented in various ways. For example, income taxes paid by a corporation can be 
compared with its receipts, property, number of employees, amount of assets, type of business, and so forth. The value of the data is obviously constrained by the way it is presented. What might be a valuable presentation for some policymakers and researchers would be irrelevant for others. By contrast, if the data are presented with the name of the corresponding corporations, researchers can correlate the tax information with any other publicly available data which they wish to utilize. Researchers can pursue whatever issues are most relevant-then, or at any time in the future. Without knowing the name of the corporations, researchers would not be able to use the information disclosed in conjunction with the information in Form 10-K's, annual reports, and other data bases.

Finally, many states today routinely publish aggregate data on corporate taxes. But the fear of violating existing laws on the privacy of tax returns constrains the publication of statistical data. Situations commonly exist in which knowing certain limited information about an unnamed corporation, such as its size and the nature of it primary business activities, allows an informed judgment to be made about its identity. Consequently, in order to avoid publishing statistical information in a manner that facilitates identifying particular corporations, a common practice is to sanitize the data by intentionally aggregating it and presenting it as part of a larger group or class. Obviously, the need to present data in a manner that protects the identity of a taxpayer reduces the value of the information that can be made public. Moreover, those situations in which the data need to be sanitized are probably those situations in which the public interest is greatest because they involve major taxpayers.

As the above demonstrates, the practice of using statistical aggregates is no substitute for data on a corporation-by-corporation basis. ${ }^{240}$ Nonetheless, the Massachusetts Special Commission suggested that firm-specific data could be released on an anonymous or coded basis. This suggestion is evaluated below. ${ }^{241}$
Publishing statistical data without identifying the taxpayers involved inevitably limits its use by researchers. 
Public understanding of seemingly complex economic issues has been essential to the development and implementation of the many important economic reforms instituted at the state and national levels during the twentieth century.

To be sure, government officials can not justify far reaching changes on the basis of anecdotal information. At the same time, however, they are unlikely to be able to enact legislation, even if based on sound theoretical and empirical reasoning, if they are unable to explain the need for such laws to the ordinary citizen; nor, in our form of democracy, should they be able to do so.

The impact that CTJ had on federal tax reform provides a dramatic example of the effectiveness of using "warm bodies" rather than impersonal data. After all, there was no shortage of statistics before CTJ's work, but the arid raw data alone was not enough to galvanize the public into supporting sweeping reform.

\section{B. Firm-Specific Disclosure is Essential to Public Understanding of Corporate Tax Issues}

Public understanding of seemingly complex economic issues has been essential to the development and implementation of the many important reforms instituted at the state and national levels during the twentieth century. Public awareness, understanding, and pressure laid the groundwork for food and drug laws, securities laws, antitrust laws, wage and hour laws, statutes regulating the rates of railroads, public utilities, and other firms with monopoly power. Public opinion was critical in supporting the corporate tax changes in the Tax Reform Act of 1986. In our system of democratic capitalism with its extensive system of checks and balances, significant economic reforms usually require the force of public opinion. Obviously, public opinion is not sufficient in and of itself for the enactment of major reforms, but it is clearly a necessary condition.

Economists, lawyers, and other "experts" can develop an understanding of complex issues in the abstract, based on either theoretical or empirical reasoning. But for the non-specialist, the intelligent layperson who is not devoting his or her working life to mastering a particular issue or problem, real-life examples help develop the necessary understanding. To be sure, government officials can not justify far reaching changes on the basis of anecdotal information. At the same time, however, they are unlikely to be able to enact legislation, even if based on sound theoretical and empirical reasoning, if they are unable to explain the need for such laws to the ordinary citizen; nor, in our form of democracy, should they be able to do so.

As the federal experience in 1986 powerfully demonstrates, without disclosure the public will remain strangers to the world of corporate tax reform. Aggregate data or even firm-specific but anonymous data ${ }^{242}$ are no substitute for disclosure.

It is a basic truth that in order to spark interest in an issue it must be made real and human. A cold statistic is just that--cold. Eyes glaze and interest wanes. Policymakers and other concerned citizens cannot have a dialogue with a statistic. The impact that CTJ had on federal tax reform provides a dramatic example of the effectiveness of using "warm bodies" rather than impersonal data. After all, there was no shortage of statistics before CTJ's work, but the arid raw data alone were not enough to galvanize the public into supporting sweeping reform.

Opponents of disclosure contend that the general public is generally unsophisticated about tax matters and would be unable to understand the significance and implications of corporate tax information. According to opponents, only tax experts can understand the multifarious and complex factors that interact to generate a corporation's tax liability. The public will merely be confused, or unreasonably angered, by learning of nominal corporate tax liabilities. The public lacks the astuteness and sophistication to appreciate why a corporation's liabilities are only nominal. ${ }^{243}$ Of course, the fact that the public is relatively uninformed about state corporate taxes is an argument in favor of--not against-disclosure.

Taken seriously, the "public will misunderstand" argument would emasculate much of the SEC disclosure requirements as well as similar provisions in other legislation. ${ }^{244}$ The lay public may not be able to read a balance sheet, but it can understand those who are able to translate the impenetrable world of financial accounting into understandable language. The public may not have comprehended the intricacies of tax shelters, accelerated depreciation, or investment tax credits, but it understood the need to 
reform the federal tax system in 1986.

This "ignorant public" argument ultimately challenges the premises underlying a democratic society. A well-functioning democracy requires an informed public. If corporations feel that the disclosed information is likely to be misinterpreted, they can educate the public by providing more information and a fuller explanation. ${ }^{245}$ If the media report a large, profitable corporation with a seemingly low tax liability, that taxpayer can use its public relations resources to explain, for example, how the existence of loss carryovers or tax credits helped lower its tax liability. ${ }^{246}$ This dialectical process is one that routinely occurs in contemporary society, exemplified by corporations that buy advertising space in newspapers and magazines regarding tort or health care reform, plant closings, labor disputes, or alleged malfeasance by corporate officers. This process plays a critical role in a healthy democracy. ${ }^{247}$ Perhaps the real fear is not that the public will misunderstand but that it will understand too well. As the Staff of the Massachusetts Special Commission on Business Tax Policy observed, "[D]isclosure of tax information on specific companies has proven to be an effective means of crystallizing support for tax reform." 248

\section{Sunlight is the Best Disinfectant: Disclosure Would Promote Openness and Accountability}

State disclosure is just another reminder that as Justice Brandeis observed, "sunlight is the best of disinfectants." ${ }^{249}$ Not surprisingly, the principal architects of the early securities acts were disciples of Justice Brandeis. ${ }^{250}$ Good government requires openness; the free flow of information is a remedy for poor policies and political ills. "Information is the currency of the 'marketplace of ideas,' the prerequisite for political selfdetermination, and a security against usurpation by secret cabals." 251 "Secrecy interferes with rational decision-making, accountability, and the choice of
Of course, the fact that the public is relatively uninformed about state corporate taxes is an argument in favor of--not against--disclosure.
This "ignorant public" argument ultimately challenges the premises underlying a democratic society. As mentioned above, a wellfunctioning democracy requires an informed public. If corporations feel that the disclosed information is likely to be misinterpreted, they can educate the public by providing more information and a fuller explanation.

State disclosure is just another reminder that as Justice Brandeis observed, "sunlight is the best of disinfectants." 
Openess and accountability make it less likely that tax laws will be made behind closed doors, where special interests are more likely to prevail over the public's interest.
"Sunlight" in regard to state corporate income tax data will help to restore confidence in both the business community and the tax system. If disclosure shows that the current tax system is working, it will help to convince the public that large businesses are indeed paying their fair share and that they are good citizens. If, on the other hand, disclosure helps to identify shortcomings in the current system, it will provide the basis for necessary reforms which will help restore public confidence in the corporate sector and the tax system. (government) goals."252 Openness and accountability make it less likely that tax laws will be made behind closed doors, where special interests are more likely to prevail over the public's interest.

The modern trend in the United States, inspired in part by the SEC, is for more--rather than less-disclosure. ${ }^{253}$ The SEC's disclosure requirements have had a "profound influence on post-World War II legislation, including the 1957 Civil Rights Act, the various air, water, and toxic substances pollution statutes, the Occupational Safety and Health Act, the Equal Employment Opportunity Act," 254 the Freedom of Information Act; ${ }^{255}$ the Truth in Lending Act; ${ }^{256}$ the Interstate Land Sales Full Disclosure Act; ${ }^{257}$ the Consumer Credit Protection Act; ${ }^{258}$ the Real Estate Settlement Procedures Act; ${ }^{259}$ the Fair Credit Reporting Act; ${ }^{260}$ and the Employee Retirement Income Security Act (Pension Reform Act). ${ }^{261}$ As these various pieces of legislation exemplify, our society has a clear bias in favor of making as much information available, not only so that we may make informed decisions, but also so that we may have confidence in our institutions. We should esteem disclosure for the same reason we should esteem 'sunlight'-- because it illuminates. ${ }^{262}$

"Sunlight" in regard to state corporate income tax data will help to restore confidence in both the business community and the tax system. If disclosure shows that large businesses are indeed paying their fair share, it will help to convince the public that the current tax system is working. If, on the other hand, disclosure helps to identify shortcomings in the current system, it will provide the basis for necessary reforms which will help restore public confidence in the corporate sector and the tax system.

\section{State-Level Disclosure Will Complement SEC-Mandated Disclosure}

Compared with the extensive information already in the public domain because of SEC requirements, state disclosure appears modest and mundane. Primarily because of the SEC, the public has been given a picture window into the financial affairs, including the income tax data of publicly-traded corporations. State disclosure would open that window a crack more.

Moreover, state-level disclosure would improve the utility of the SEC-required information to many users of financial statements. Among the primary users of the tax information in SEC-mandated financial statements are securities analysts and other financial analysts who evaluate the financial performance of publicly-traded corporations. Many occasions exist when an analyst must remove an unusual and non-recurring income or expense from an income statement in order to evaluate the on-going performance of the corporation involved; for example, in attempting to assess the quality 
of a firm's earnings and the trends in its income and expenses that are likely to continue. "When a nonrecurring item needs to be removed from the income statement, the tax results of that item also need to be removed."263 A failure to take the tax consequences of such an item into consideration will distort the analysis of income by the use of an improper tax rate and will also result in an inconsistent presentation of the balance sheet. Although the SECrequired disclosure is sufficient to adjust for the federal consequences of the item involved, it will in many cases not be sufficient to make the necessary change in the state tax results of the item.

The SEC-disclosed federal tax information is also used by analysts to determine how well or poorly the company's management handles tax planning and implementation. ${ }^{264}$ This aspect of the analyst's work could also be enhanced by the availability of state-specific data.

Some critics of state-level disclosure have argued that the availability of information on a firm's state tax liability might somehow disclose proprietary information. ${ }^{265}$ If this were true, then the current SEC requirement for disclosure of the aggregate amount of state income taxes would have more of a negative impact on those corporations paying state income taxes to only one (or a few) states than on those operating nationwide or internationally. State disclosure would then level the playing field among these publiclytraded corporations.

State disclosure would level the playing field in yet a different manner. According to some commentators, the public knows a great deal about small and medium corporations because they are more specialized than larger corporations. For the smaller, more specialized corporations, the annual report and Form $10-\mathrm{K}$ provide real insight into their line of business. "But not so with a large conglomerate corporation whose annual report masks more than it reveals. Not surprisingly, therefore, it is the large corporation that invariably resists steps to strengthen disclosure requirements--steps that in practice would, at most, place it on a par with smaller corporations." 266

\section{E. Why Not Disclose Firm- Specific Data Anonymously?}

The Massachusetts Special Commission on Business Tax Policy recommended that their state's current law be amended to provide that the required data be released on a corporation-by-corporation basis but without identifying the name of the corporation. ${ }^{267}$ For example, information on each corporation would be available but a corporation might be identified only by a number that would not reveal its identity.

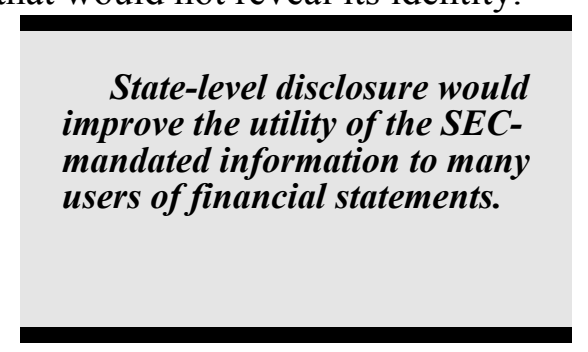

Although this approach would allow outliers to be identified rather than being buried in a statistical aggregate, the other inherent defects of using aggregates would remain. For example, the enhancement of public and legislative understanding would be as difficult to achieve with anonymous corporation-by-corpora-
Although the SEC-required disclosure is sufficient for a securities analyst to adjust for the federal tax consequence of unusual and non-recurring items of income and expense, it will in many cases not be sufficient to make the necessary change in the state tax results of the item. 
The enhancement of public and legislative understanding would be as difficult to achieve with anonymous corporation-bycorporation data as it has proven to be when only aggregates are available. In addition, researchers would be limited to only what was published and would have no way of tapping alternative sources of data. The crosstabulation of disclosed and nondisclosed data would be impossible.

None of the goals of accountability, openness in government, and the involvement of the public in issues of tax reform are likely to be achieved with anonymous disclosure. tion data as it has proven to be when only aggregates are available. In addition, researchers would be limited to only what was published and would have no way of tapping other sources of data. The crosstabulation of the disclosed tax data with other publicly-available information would be impossible. Longitudinal studies would be difficult, as would studies about the effectiveness of tax incentives. ${ }^{268}$ Corporations would still be able to take public positions that would be inconsistent with the facts. None of the goals of accountability, openness in government, and the involvement of the public in issues of tax reform are likely to be achieved with anonymous disclosure. After all, information that Corporation \#123 has paid the minimum tax despite over $\$ 100$ million of profits will be unlikely to have any lasting effect on tax reform. By comparison, disclosure, by name of corporation, has proven to be an effective means of increasing public understanding of tax reform issues. ${ }^{269}$

Anonymous disclosure will be particularly problematical in states in which the disclosure system is being administered by an agency other than the state tax department. In Massachusetts, the administering official (the Secretary of State) has no basis on which to evaluate the accuracy of the information submitted. With anonymous disclosure, this problem is compounded because the information submitted by a firm does not have to stand the test of public scrutiny by those who would have a basis for evaluating its accuracy in terms of general orders of magnitude. This might include securities analysts, other researchers and tax reform groups. The disclosure of firm-specific data without corporate names would make it impossible to do interindustry or intraindustry comparisons. It would also make it impossible to match the disclosed tax information with other publicly available data on employment, investment, and other relevant factors. And, if the same code number was not assigned to a firm every year, it would not be possible to do even limited longitudinal analyses.

Finally, anonymous disclosure will inevitably lead to public speculation about which corporations are involved. ${ }^{270}$ Because the benefits of anonymous disclosure are insignificant, a state might as well dash public speculation by identifying the corporations by name. Indeed, if disclosure provides valuable information to competitors as opponents have argued, ${ }^{271}$ these competitors can be expected to try to match the information released with public information from Form 10-K and other sources. Those willing to go to this trouble will presumably be able to break through the anonymity. Consequently, anonymous disclosure does not protect against any competitive disadvantages but only against public attention and scrutiny.

The above discussion, combined with the favorable experience at the national and to a more limited extent at the state levels, establish a presumptive case in favor of disclosure. Unless compelling reasons exist, state tax data should not be immunized from public scrutiny. The remainder of this Section $^{272}$ examines such reasons.

\section{F. Will Disclosure Violate a Corporation's Right to Privacy?}

The extent of SEC-required disclosure of information by publicly-traded corporations makes it obvious that such corporations have long ago surrendered any claim that their financial data should be protected under some right of privacy. If the disclosure of their federal income tax liabilities and other financial information does not raise a constitutional issue, then neither should the disclosure of their state tax information. As early as 1911, the U.S. Supreme Court upheld a federal law that provided for the public inspection of corporate 
tax returns against attacks that it was unconstitutional. ${ }^{273}$ The modern day embodiment of this argument is that disclosure will reveal proprietary information. $^{274}$

To be sure, in certain situations the business affairs of a corporation may be closely identified with that of the shareholders. Revealing the taxes paid by a small, mom and pop, closely-held corporation might be viewed as violating legitimate expectations of privacy by its shareholders. However, such corporations would be exempted from disclosure requirements limited to publicly-traded firms. ${ }^{275}$

\section{G. Will Disclosure Reveal Proprietary Information?}

A corporation can assert a legitimate interest in protecting the confidentiality of proprietary information. Opponents of disclosure assert that revealing the amount of a corporation's state tax data would reveal proprietary information. $^{276}$ These kinds of arguments have long marked debates over the disclosure of any kind of financial information. "The reluctance of many business corporations in the pre-1933 period to disclose what today is considered essential balance sheet and income statement data and the more recent reluctance of many firms to disclose (or effectively disclose) line-ofbusiness data or earnings projections often has been explained by business representatives as fear of revealing useful data to competitors." 277 Typically, these arguments are based more on fear than on reality. To illustrate, consider the following argument used by A.H. Belo Corp. (owner of the Dallas Morning News) against a minority shareholder proposal that it become a publiclylisted company:

The company maintains that publishing information required of public companies by the SEC would put it at a severe competitive disadvantage, since the data would be available to its main competitor, the Dallas Times Herald, which is owned by Times Mirror Co., Los Angeles. Belo maintains that because it is significantly smaller than Times Mirror, financial disclosures required by the SEC would reveal too much of its inner workings. Times Mirror owns several major papers and can group its newspaper financial data for reporting purposes. By contrast, the Dallas Morning News is the only major newspaper property of Belo. ${ }^{278}$

The extent of SEC-required disclosure of information by publicly-traded corporations makes it obvious that such corporations have long ago surrendered any claim that their financial data should be protected under some right of privacy. 
Opponents argued that the disclosure of tax information would be valuable to competitors since it would reveal tax strategy, but no examples were provided and the SEC concluded that the needs of present and potential investors in public corporations are best served by providing such disclosure.

The opponents of disclosure have never been able to articulate how knowing the amount of tax that a competitor paid reveals anything of competitive value. For information to be valuable, a business needs to know yesterday what a competitor is going to do tomorrow.

Yesterday's information obtained tomorrow is worthless.

For information to be valuable, a business needs to know yesterday what a competitor is going to do tomorrow. Yesterday's information obtained tomorrow is worthless.
In responding to the company's argument, one commentator notes that "on at least the revenue side, competing sources already provide considerable information about the Dallas Morning News. This paper is a member of the Audit Bureau of Circulation which publishes very detailed unit circulation figures on the Dallas Morning News every six months.

"The advertising rates of the paper are readily available to an external party in a booklet titled Retail Advertising Rates. The list of advertising clients of the paper is available for $15 \notin$ a day $(50 \notin$ on Sunday). These competing sources of information are considerably more detailed and cover more facets than does the 'sales' figure required in the $10 \mathrm{~K}$ of a publicly listed company."279

The same competitive arguments were made in 1973 against the SEC's successful proposal to require more extensive reporting of federal income tax data. ${ }^{280}$ Opponents argued that the disclosure of tax information would be valuable to competitors since it would reveal tax strategy, ${ }^{281}$ but no examples were provided and the SEC concluded that the needs of present and potential investors in public corporations are best served by providing such significant information even though there may be an increased risk of adverse consequences at the hands of competitors. ${ }^{282}$ SEC and other federal laws already require many corporations to disclose extensive tax and financial information, and apparently such disclosures have not jeopardized the economic interests of the corporations.

When pressed, those who argue that disclosure will reveal proprietary information have never been able to provide a detailed illustration. ${ }^{283}$ The opponents of disclosure have never been able to articulate how knowing the amount of tax that a competitor paid reveals anything of competitive value. Moreover, even if this information were relevant in the abstract, it is unlikely to be available in a timely-enough fashion to be very useful. For information to be valuable, a business needs to know yesterday what a competitor is going to do tomorrow. By the time a corporation requests the normal extensions and files its return--a precondition to the public's gaining access to whatever tax information is subject to disclosure--the information will be stale (or could be aged to ensure that it was stale). Yesterday's information obtained tomorrow is worthless. For a businessperson to learn two years after the fact that a competitor paid $\$ \mathrm{X}$ in state taxes or claimed \$Y in state credits pales by comparison with what can learned by reading the trade press, schmoozing at trade shows and conventions, searching computer data bases, or hanging out at the local bars that dot large plants--all traditional ways of obtaining current information about competitors.

In investigating the degree to which information divulged under Massachusetts law might be useful to competitors, the staff of the Massachusetts Special Commission on Business Tax Policy interviewed twelve industry analysts who specialized in different industries including banking, life insurance, biotechnology, electronic components, retailing, and computer services. Of the twelve, eight stated that Massachusetts law would reveal little information of value to competitors for the following reasons: 1) comparable

information is available from other reports, such as annual financial reports and reports compiled by consulting firms and underwriters; 2) the information would not be disaggregated enough to be of much value, even if reported on a subsidiary-by-subsidiary basis; $;{ }^{284} 3$ ) tax accounting principles differ so much from financial accounting principles (especially in the case of banks), that tax information provides very little insight into the financial condition and operational characteristics of a company; 4) the information would be disclosed with a long lag; 5) companies have the option of disclosing either gross profit or tax credit carryovers under 
Massachusetts law.

One analyst suggested that disclosure might provide insight into product trends and profitability which, over time, might allow competitors to determine business strategies. How a competitor might determine business strategies from the disclosed tax information was never explained. It was also alleged that corporate raiders could use the information to help them select targets for hostile takeovers, ${ }^{285}$ which seems somewhat fanciful because of the time lags involved. Takeover targets are most likely to be selected based on the best and most current information available about a firm's national (and international) financial condition. Massachusetts tax information, disclosed two or more years after the fact, could hardly add much of relevance. The analyst stated that the resulting anticompetitive damage would be most severe in industries where the pace of innovation is slow but price competition is intense, such as retailing. But another analyst, specializing in retailing, felt that the data divulged in tax disclosure reports would reveal nothing that rivals do not already know from other sources.

Yet another analyst agreed that disclosure would be especially harmful to retailers because it would provide insights into the profitability of Massachusetts retail markets with respect to those of other states. Also, by analyzing the tax data of specific stores, in conjunction with other publicly available data, competitors would gain insights into which products in Massachusetts stores are most profitable. ${ }^{286}$ Out-of-state rivals could use the data to decide whether to expand stores and which products it should market aggressively within that state.

Left unexplained, once again, was how tax data would help identify which products were most profitable. A retailer, such as a department store, might sell thousands of different products. And, even assuming that the pace of innovation is slow in retailing, certainly fads exist and this year's hot seller may well be next year's dog. The time lag inevitable under any disclosure law would seem to limit the usefulness of any information released for such purposes. It is unclear how a competitor would be helped by learning about which products were relatively more profitable two or so years ago. Finally, in areas of

In investigating the degree to which information divulged under Massachusetts law might be useful to competitors, the staff of the Massachusetts Special Commission on Business Tax Policy interviewed twelve industry analysts who specialized in different industries including banking, life insurance, biotechnology, electronic components, retailing, and computer services. Of the twelve, eight stated that Massachusetts law would reveal little information of value to competitors.

retailing, such as apparel, where orders are typically placed months in advance of sale, it is not even clear how a competitor might

It was also alleged that corporate raiders could use the information to help them select targets for hostile takeovers, which seems somewhat fanciful because of the time lags involved. Massachusetts tax information, disclosed two or more years after the fact, could hardly be add much of relevance. 
To the extent that disclosure leads to more competition, it is consistent with a market economy. "Contrary to the assertions of many corporate spokesmen, corporate secrecy-not corporate disclosure--is the great enemy of a market economy in a free society." capitalize on information that was current, rather than being at least one year old.

An analyst specializing in life insurance commented on the possible competitive harm that tax disclosure will inflict on automobile insurers. In the view of this analyst, many auto insurers believe that Massachusetts is an unattractive place to do business because of its reputation for bad drivers. Recently, however, automobile insurance has been profitable. Yet, because the perception that Massachusetts is a poor market lingers, out-of-state competitors stay away.

If believable, these comments describe a rather unsophisticated insurance industry -- one in which automobile insurers have no more refined information about the Massachusetts market than its reputation, whether deserved or not, for having poor drivers. Presumably the industry has better means than hearsay of determining whether automobile insurance is profitable in Massachusetts.

But more fundamentally, suppose the analyst is correct and because of disclosure more insurance companies started to write policies in Massachusetts. Presumably, this competition would be good for policyholders, resulting in lower premiums and greater choice of options. Indeed, one of the characteristics of a market economy is the general bias in favor of the free flow of information. Unlike a patent or a copyright, or some other form of intellectual property, a company should not be able to assert a proprietary interest in whether Massachusetts is a profitable place to write car insurance. Similarly, to the extent that disclosure would increase competition in retailing, consumers would ultimately benefit from the lower prices. Moreover, increased jobs might also be expected. ${ }^{287}$

Indeed, an accepted goal of disclosure in other contexts is increased competition. For example, the Federal Trade Commission's "Line of Business" (LOB) disclosures instituted in 1974 had as one of their beneficial effects the "increased competition in product markets; firms considering entry into new markets would be better able to discern existing 'excess' profit situations." 288

To the extent that disclosure leads to more competition, it is consistent with a market economy. "Contrary to the assertions of many corporate spokesmen, corporate secrecy--not corporate disclosure--is the great enemy of a market economy in a free society." 289 A market economy relies on the self-corrective mechanism of the marketplace to keep competition robust and monopoly in check. A firm that holds a strong market position resulting in higher than ordinary profits induces the entry into the field of new businesses. ${ }^{290}$ To the extent that disclosure reinforces this mechanism, it facilitates the dynamics of a market economy. This philosophy is similar to that underlying the SEC disclosure rules: "The idea of a free and open public market is built upon the theory that competing judgments of buyers or sellers as to the fair price of the security brings about a situation where the market price reflects as nearly as possible a just price....There cannot be honest markets without honest publicity."291 Consequently, even assuming the analyst is correct does not necessarily tip the balance in favor of nondisclosure.

Further evidence that the competitive harm argument might be exaggerated comes from Arkansas, where businesses subject to disclosure can apply for an exemption on the grounds that the release of the requested information would result in competitive harm. Apparently, very few businesses have ever requested such an exemption, ${ }^{292}$ although the seven day period may be short enough to discourage such requests. To be sure, the Arkansas procedure provides a safety valve; the risk is that in a state such as Massachusetts where the business community has 
aggressively fought against disclosure, the safety valve will turn into a dilatory tactic to undercut the law.

\section{H. Will Disclosure Discourage the Filing of Accurate Tax Returns?}

The successful operation of the U.S. income tax depends on the voluntary cooperation of taxpayers. A commonly stated rationale for protecting the confidentiality of tax information is to facilitate tax enforcement by encouraging a taxpayer to make full and truthful declarations in its return, without fear that those statements will be revealed or used against it for other purposes. The assumption is that even limited access by government agencies to information obtained from tax returns will deter some taxpayers from truthful reporting. Secrecy is a necessary palliative to taxpayers who might otherwise falsify their tax returns if they knew that non-tax officials would have access to that information.

The "full and frank disclosure" rationale presumes that secrecy helps assure honesty and that publicity discourages it. ${ }^{293}$ If this presumption is correct, the SEC reporting requirements must have led to less honest tax returns--a position that apparently has never been argued in the literature--and one that seems far fetched on its face. If corporations were not induced to file false federal returns by SEC disclosure, why should it be assumed they will do so in response to state disclosure?

Moreover, some researchers have even cast doubt on the asserted relationship between tax return confidentiality and honest reporting by examining a 1976 federal change, in response to Watergate, which dramatically increased the degree of confidentiality accorded federal income tax returns. Proponents of the change had predicted that the increased level of confidentiality would encourage more honest reporting but apparently voluntary compliance actually decreased. ${ }^{294}$

Contrary to the thesis that secrecy induces honest reporting, it could be argued that if taxpayers are publicly accountable for the information furnished on their income tax returns, their incentive to report truthfully would be even greater. Publicity would increase the possibility that employees, competitors, or other business persons will notice glaring omissions and bring it to the attention of the tax authorities.

Public disclosure might actually discourage corporations from minimizing their tax liabilities through tax avoidance techniques. For public relations purposes,

The "full and frank

disclosure" rationale presumes that secrecy helps assure honesty and that publicity discourages it. If this presumption is correct, the SEC reporting requirements must have led to less honest tax returns--a position that apparently has never been argued in the literature--and one that seems far fetched on its face.

If corporations were not induced to file false federal returns by SEC disclosure, why should it be assumed they will do so in response to state disclosure? 
Public disclosure might actually discourage corporations from minimizing their tax liabilities through tax avoidance techniques. For public relations purposes, corporations required to disclose tax information might be leery of paying only nominal amounts of tax. corporations required to disclose tax information might be leery of paying only nominal amounts of tax. The scrutiny of the public and the possibility that increased publicity would aid taxing authorities in detecting illegitimate tax avoidance or fraud could help safeguard the integrity of the corporate income tax.

In reality, little is definitively known about the effects of confidentiality on taxpayer behavior and whether, for this purpose, large corporations should be distinguished from small corporations and individuals. Nor is tax disclosure defended by its supporters as a way of increasing taxpayer compliance. ${ }^{295}$ Tax withholding, information returns, civil and criminal sanctions, and information sharing with other taxing authorities all help to insure voluntary corporate compliance with tax laws. The role played by the confidentiality of returns is simply unknown. Accordingly, both the direction and magnitude of the impact disclosure might have on corporate reporting, especially if only a limited range of information will be published, is sheer speculation.

\section{Will Disclosure Undercut a State's "Business Climate?"}

Opponents of disclosure argue that it would reflect or exacerbate an anti-business climate in the state. Disclosing corporate taxes would antagonize the business community and fuel the hostility of its enemies. Opponents argue that it would detract from the aura of goodwill that creates a positive "business climate," and would provide one more weight in the balance of factors that may ultimately influence a corporation to relocate its business to a friendlier state. ${ }^{296}$

On a general level, this argument proves too much. Any legislation that the corporate community opposes can be characterized as poisoning the business climate. Obviously, in considering any legislative proposal, the intended benefits must be weighed against possible deleterious effects.

On a more specific level, evaluating this argument is difficult because the factors that comprise a state's "business climate" elude easy analysis. Many considerations affect a corporation's view of a state's business climate, and the issues important to one corporation may be unimportant to another.

Factors that might contribute to a specific corporation's perception include the cost of energy, land, labor, or transportation; zoning regulations; restrictions on construction; the attitude of those public officials with whom a firm most often deals; the speed with which telephone calls are returned from the public sector; the degree of governmental regulations; the way businesses are treated by a tax department's auditors; the level of civility that characterizes interaction with government personnel; the amount of red tape that exists; the number of forms and permits required; and the governmental assistance provided to a new firm and its employees in relocating. ${ }^{297}$ Perceptions of business climate are also based on intangibles and imponderables that defy easy analysis or quantification (e.g., personal idiosyncracies of executives). But unlike many of the factors that affect the business climate the disclosure of corporate tax information would not affect the cost of doing business or a corporation's "bottom line." 298

There are many provisions in a tax code that are adopted to improve the business climate. Some of these provisions were even adopted at the specific request of a corporation, in an attempt by a legislature to induce the corporation to invest in a state (or to remain or expand its operations in a state). It is disingenuous to use the business climate argument in support of the adoption of these provisions and then use the same argument to prevent the public from evaluating in a meaningful way the effectiveness of such provisions.

Even if disclosure were viewed as 
undercutting the business climate, it is not clear what defensive actions a corporation would take. If disclosure is limited to all publicly-traded corporations that do business in the state, there would be two ways of avoiding this requirement. The first is to cease doing business in the state by removing all property and personnel and basically conduct a mail order business. ${ }^{299}$ The second is to conduct business in a noncorporate form. Both would be rather extreme reactions. ${ }^{300}$ If a corporation felt so strongly about avoiding state disclosure that it would operate as a partnership, presumably it would have already done so to avoid the SEC's rules on disclosure. Of course, this option could be precluded if disclosure were extended to partnerships above a certain size. ${ }^{301}$

Any legislative proposal to withdraw, albeit slightly, the cloak of secrecy that protects the confidentiality of corporate income tax data will be controversial. But not all businesses might resist such a proposal, and some might actually welcome it, if only to dispel the negative image that corporations are somehow tax freeloaders. Corporations that pay little or no income tax may be few in number but, in the public's mind, might be seen as representative of business in general.

Disclosure of tax information could help to correct the perception that corporations are all under taxed, and thereby enhance, rather than prejudice, attitudes toward business. Moreover, some businesses might respect, if not welcome, legislative efforts directed at examining an important component of the state's revenue structure.

Should disclosure lead to a more level playing field, as it did at the federal level in 1986, businesses in general will benefit. A state that rewards corporations for their business decisions rather than their tax decisions ought to be viewed as advancing the business climate. ${ }^{302}$

Finally, the business community has some control over how the media and corporations in other states will come to view a disclosure law. If the business community characterizes a disclosure law as evidence of a state's fiscal responsibility, its desire to introduce more responsibility and openness into government, and its willingness to eliminate waste and inefficiency in its tax system, the business climate should be enhanced rather than undercut. ${ }^{303}$

There are many provisions in a tax code that are adopted to improve the business climate. It is disingenuous to use the business climate argument in support of the adoption of these provisions and then use the same argument to prevent the public from evaluating in a meaningful way the effectiveness of such provisions.

Unlike many of the factors that affect the business climate the disclosure of corporate tax information would not affect the cost of doing business or a corporation's "bottom line."

Disclosure of tax information could help to correct the public perception that corporations are all under taxed, and thereby enhance, rather than prejudice, attitudes toward business.
If the business community characterized a disclosure law as evidence of a state's fiscal responsibility, its desire to introduce more responsibility and openness into government, and its willingness to eliminate waste and inefficiency in its tax system, the business climate should be enhanced rather than undercut.
State-level disclosure holds the promise of significant benefits. The arguments against disclosure do not provide a basis for rejecting the case in favor. And, some of those arguments, when carefully analyzed, actually support the case for additional disclosure. 


\section{J. Conclusion}

This Section examined the case for and against disclosure. Based on CTJ's experience with SECmandated disclosure and the limited state experience, state-level disclosure holds the promise of significant benefits. The arguments against disclosure, many of which could also be made (and in some cases have been made) against SECmandated disclosure, do not provide any reasons to reject the case in favor. And some of the arguments against disclosure, when analyzed, turn into arguments on behalf of disclosure. Consequently, the next Section discusses three major issues that need to be resolved in formulating state-level disclosure policy: who should be covered by disclosure; what information should be disclosed; and which state agency should administer disclosure. 


\section{Formulating State Disclosure Policy}

\section{A. Who Should be Covered by Disclosure?}

Although there are situations where the law requires financial information about individuals to be disclosed to the public, ${ }^{304}$ individuals are generally perceived and treated as having greater rights of privacy than do corporations. The most compelling arguments in the congressional debate over public access to tax returns centered on individuals and their rights to privacy. There should be a higher burden of proof than in the case of publicly-traded corporations that disclosure of individual tax information justifies the resulting loss of privacy. With the exception of individuals who are the beneficiaries of significant tax expenditures, ${ }^{305}$ this higher standard does not justify the wholesale release of individual tax information. ${ }^{306}$

In addition to publicly-traded corporations, ${ }^{307}$ disclosure should also be extended to firms in regulated industries such as banks, utilities, and insurance companies, whether publicly-traded or not. These corporations are key economic actors in which the public has a well established special interest, as evidenced by the extensive reporting and regulatory provisions to which they are subject. Because they already submit extensive financial data to state authorities, no new privacy issues or compliance burdens arise by bringing them within the purview of a disclosure law. ${ }^{308}$

Corporations that are publiclytraded on foreign exchanges should also be included for purposes of disclosure. Many developed countries have financial disclosure laws similar to those of the United States. Although in some cases these laws may not be as detailed as those of the United States, the principle of disclosure is well established. All the reasons for including U.S. publicly-traded corporations within a disclosure law extend equally to foreign-traded corporations. Treating both groups the same preserves a level playing field.

At a minimum, disclosure should cover publicly-traded corporations, whether domestic or foreign, doing business in the state, and banks, insurance companies, and utilities, doing business in the state, whether publicly-traded or not. All of these corporations are already used to publishing detailed financial information about their operations, including extensive data on their federal tax liabilities. These corporations have long ago surrendered claims of confidentiality and privacy regarding their financial affairs. Requiring state-specific information to be released is a small additional compliance burden.

Publicly traded corporations are already used to publishing detailed financial information about their operations, including extensive data on their federal tax liabilities. Requiring state-specific information to be released is a small additional compliance burden. 
The public's right to know who is receiving public funds should not be undercut simply because benefits are being offered through the tax system rather than through direct spending programs.
Some states might wish to extend disclosure to large corporations that are privately-held, such as Bechtel, Mars, UPS, Caltex Petroleum, Egghead, Computerland, Milliken, Montgomery Ward, American Standard, Revco, Wordperfect and Gateway Computers. ${ }^{309}$ Large, privately-held corporations are key participants in a state's economy and may also be responsible for helping to shape a state's tax regime. Unlike small "mom and pop" corporations, large privately-held corporations are not merely the alter ego's of their owners and the business matters of the corporation are not inextricably intermingled with the individual shareholder's personal financial affairs.

Moreover, unlike a small "mom and pop" corporation, large privately-held corporations can easily comply with a disclosure law. Accordingly, a state could set forth certain criteria (e.g., assets, income, net worth) to determine which privately-held corporations might be subject to disclosure.

In the case of tax expenditures, those situations in which a state "spends" money through special nonnormative tax provisions, such as tax credits or special deductions or exemptions, ${ }^{310}$ disclosure should be extended to all beneficiaries, whether publicly traded or not, and whether corporate or individual. ${ }^{311}$ The increased accountability and openness that would accompany disclosure can properly be viewed as a legitimate requirement of any entity or individual benefitting from the expenditure of public funds. Indeed, one of the major arguments in favor of SEC-disclosure applies equally to identifying the beneficiaries of tax expenditures: "The financial community, the accounting profession, the bar and industry generally have come not only to accept but to support the principle that those who make use of the public's money must supply the information essential to the formulation of intelligent investment decisions, and that it is a proper responsibility of government to keep an eye on the accuracy and adequacy of such information." 312

Further, identifying beneficiaries by name is consistent with the philosophy underlying the concept of a tax expenditure. The major tax expenditures tend to be investmentrelated subsidies, like an investment tax credit. If these expenditures took the form of an explicit spending program, the identity of the recipients would most likely be public information either as part of the application process for the subsidy or through freedom of information laws. Information that sensibly would be made public as part of a spending program should be similarly disclosed as part of a tax expenditure analysis. The public's right to know who is receiving public funds should not be undercut simply because benefits are being offered through the tax system rather than through direct spending programs. To make the flow of information manageable, however, only corporations or individuals receiving tax expenditures above a certain aggregate amount should be subject to disclosure.

\section{B. What Information Should be Disclosed?}

\section{Tax Expenditures}

Conceptually, any tax can be analyzed as if it consisted of two distinct structures. The first would be its normative structure; for example, those provisions that are necessary parts of a tax structure intended to tax only "income." These provisions would include rules on defining gross income, business deductions, the apportionment formula, and so forth.

A second set of provisions are known as tax expenditures. All governments use their tax systems for more than just the raising of revenue. Tax laws typically contain provisions intended to subsidize 
favored economic activities or to relieve personal hardships. These provisions accomplish their goals by granting a tax reduction to selected taxpayers.

Because these "subsidy" or "relief" measures are spending programs implemented through the tax system, they commonly are known as tax expenditures. ${ }^{314}$ A tax expenditure can be viewed as if the taxpayer had actually paid the full amount of tax owed in the absence of the special provision and had simultaneously received a grant equal to the savings provided by the special provision. Characterized in this manner, a tax expenditure is just one of a number of ways of providing governmental assistance and should be reexamined periodically using traditional budget and funding criteria: How much money is being spent; how is the money being distributed; is the expenditure achieving its intended goal; and is the expenditure the best means of achieving such a goal?

The concept of a tax expenditure is a powerful analytical tool that has revamped traditional ways of viewing a tax system. One application of the concept has been the compilation of a tax expenditure budget, which identifies "subsidy" or "relief" provisions and estimates their cost in forgone revenue. ${ }^{315} \mathrm{In}$ 1968, the Treasury Department published a tax expenditure budget ${ }^{316}$ analyzing the federal personal and corporate income taxes. In 1974, the Congressional Budget Office began publishing its own annual tax expenditure report, and in the same year the Office of Management and Budget began including a tax expenditure analysis with the President's annual budget request to the Congress. No doubt inspired by these federal actions, the concept of a tax expenditure budget spread to the states. By 1993, 22 states prepared some form of tax expenditure budget. ${ }^{317}$

An unusually voluminous and fertile literature exists on the concept of a tax expenditure. ${ }^{318}$ That literature makes a convincing case that unless attention is paid to tax expenditures, a state does not have either its tax policy or its budget policy under full control. ${ }^{319}$ The State of New York provides dramatic evidence of the correctness of this warning. In 1969, New York adopted an investment tax credit (ITC) without any revenue estimate of its cost. By 1983, more than $\$ 660$ million of investment-related tax credits had been claimed by corporations.

Tax expenditures should be reexamined periodically using traditional budget and funding criteria: How much money is being spent; how is the money being distributed; is the expenditure achieving its intended goal; and is the expenditure the best means of achieving such a goal? 
Because tax expenditures represent silent or back door spending, which should be scrutinized annually the same as explicit spending programs that are formally included in a budget, they should clearly be part of any information that is disclosed on a corporation-bycorporation basis.
In 1982, the most recent year for which detailed data are available, two corporations used nearly 40 percent of the total amount of credits used that year. ${ }^{320}$ Until a 1985 report by New York's Legislative Tax Study Com-mission, ${ }^{321}$ the investment tax credit, estimated to cost \$224 million in 1993--more than the budgets of most state agencies-received less review and analysis than did explicit spending programs that cost a million dollars or less. For the 1986 liability year, $82 \%$ of the credits earned in that year went to companies paying New York's minimum tax. ${ }^{322}$ It is inconceivable that had the investment tax credit been implemented as an explicit spending program, 16 years would have elapsed before any rigorous study was undertaken.

Without identifying the corporate beneficiaries, it is difficult, if not impossible, to evaluate whether and to what extent a credit such as the ITC, is helping or hurting a state. For example, are companies receiving credits for consolidating a factory while moving most of their operations out-of-state? Is the credit encouraging the purchase of machines that eliminate jobs?

Once a spending program is adopted in the guise of a tax provision, it tends to escape the same level of accountability that is applied to explicit expenditures. Because tax expenditures represent silent or back door spending, which should be scrutinized annually the same as explicit spending programs that are formally included in a budget, they should clearly be part of any information that is disclosed on a corporation-by-corporation

basis. $^{323}$ This information is easily understandable and explainable to legislators and should be of concern to policy makers and analysts on an ongoing basis.

The type of information disclosed will be determined by the nature of the tax expenditure. At a minimum, the amount of the special tax provision claimed along with the resulting tax savings should be disclosed by name of beneficiary. ${ }^{324}$ In the case of an investment tax credit, for example, the amount of the credit claimed, the amount used, the amount of any carryovers, the amount of the investment that triggered the credit should all be disclosed. ${ }^{325}$ Similarly, if a credit is based on a certain amount of employment, or research and development, those amounts should also be disclosed. Depending on the nature of the tax expenditure, the reasons leading to its adoption, plus other state-specific features surrounding its use, a state might wish to have other information disclosed that would aid in evaluating the efficacy of the tax expenditure.

\section{Normative Provisions}

Normative provisions of a state corporate income tax are not motivated by the same subsidy or relief considerations underlying the adoption of tax expenditures. Nonetheless, normative provisions represent a series of policy decisions and trade-offs among competing values, such as administrative convenience, 
simplicity, equity, economic neutrality, and efficiency. These trade-offs were often made decades ago and remain memorialized in existing statutes. Recent developments and trends challenge the premises underlying the tradeoffs. These trade-offs need to be reexamined because of changes in the judicial climate; a relaxation of federal controls, especially in the areas of transportation, communications, and banking; startling advances in technology that have facilitated innovative business practices; a flurry of federal tax legislation; the rise of multinational corporations and conglomerates; and the shift in the economy from manufacturing to services. ${ }^{326}$

The nature of the information disclosed with respect to the normative provisions of a tax might vary among the states because of state-specific statutory differences. Nevertheless, although the states vary in the details of their approaches, there are more similarities than differences so that some general observations are appropriate.

At the least, it is useful to disclose any gaps between a corporation's income for financial accounting purposes and its federal taxable income, which to one degree or another is the starting point in calculating most states' income taxes. Accordingly, a corporation might be required to disclose its accounting book income and identify significant differences between that amount and its federal taxable income.
Many provisions in a state income tax are automatically incorporated from federal law. For example, with varying degrees of fidelity all states base their definition of taxable income upon the federal definition. But provisions that are normative in the context of the federal system may be problematic in the context of a state income tax.

Consider, for example, the socalled dividends received deduction. For federal purposes, a corporation may deduct at a minimum $70 \%$ of the dividends received from taxable domestic corporations; $80 \%$ may be deducted if the dividends are received from a corporation in which the payee owns at least a $20 \%$ interest; and $100 \%$ may be deducted if the payee owns at least an $80 \%$ interest. $^{327}$ Many states track this feature of federal law; ${ }^{328}$ others provide even more generous treatment by allowing a deduction for all dividends. ${ }^{329}$

The deduction for intercorporate dividends serves as a useful example because in most states it is a longstanding provision that rests on questionable assumptions that need to be reexamined. The normative rationale for the federal dividends received deduction is the elimination of multiple taxation. ${ }^{330}$ The profits out of which the dividend is paid have already been taxed at the federal level as income of the payor. A legitimate policy question arises whether those same profits should be taxed again at the federal level when received by the payee.
The normative provisions of a state corporate income tax represent a series of policy decisions and trade-offs among competing values, often made decades ago and memorialized in law.

At the least, it is useful to disclose any gaps between a corporation's income for financial accounting purposes and its federal taxable income, which to one degree or another is the starting point in calculating most states' income taxes. 
At present, most states probably have no information on the amount or distribution of revenue they forgo by adopting implicitly features of the Internal Revenue Code. Such information would not necessarily be included in a tax expenditure budget. Disclosing by name of corporation the amount that it benefits from a federal provision that is adopted by state law is a necessary first step in identifying which provisions should be subject to a cost benefit analysis.

Many states allow corporations to claim additional deductions in moving from federal taxable income to state taxable income. The more significant of these should also be subject to disclosure.
At the state level, however, the state levying a tax on the payee is not necessarily the same state that is taxing the profits out of which the dividend was paid. As an additional complication, even if the same state taxed the profits out of which the dividend is paid, the business apportionment factor of the payor is unlikely to be identical to the business apportionment factor of the payee. ${ }^{331}$ In other words, the premises upon which the federal dividend received deduction is based are not equally relevant in the context of a state income tax.

The dividend received deduction was purposely chosen as an illustration. First, it nicely demonstrates the possibility of state law going astray when it blindly mimics a federal provision. Second, the dividend received deduction is the kind of longstanding tax provision that escapes the attention of most legislators. Third, administrative convenience, which often explains why a state incorporates a federal provision, ${ }^{332}$ do not carry much weight with respect to this deduction. A corporation can

easily add back in calculating its state taxable income the amount of its federal dividend received deduction, which appears on a separate schedule on the federal corporate return. ${ }^{333}$ Fourth, the state dividend received deduction can result in the restructuring of a multistate business for tax avoidance purposes.

For example, consider a corporation that is conducting a multijurisdictional business, taxable in State A. Assume A allows a $100 \%$ dividend received deduction. Orthodox tax planning would determine whether the corporation could reduce its tax liability in A by incorporating its out-of-state division and repatriating the profits of the subsidiary as a tax-free dividend. ${ }^{334}$ This type of tax planning might well escape attention. ${ }^{335}$

In addition to the dividend received deduction, a state might well be interested in identifying other provisions that it automatically incorporates by using federal taxable income as its starting point. ${ }^{336} \mathrm{~A}$ state might find that the reasons that led to the federal deduction might carry little weight at the state level.

At present, most states probably have no information on the amount or distribution of revenue they forgo by adopting implicitly features of the Internal Revenue Code. Such information would not necessarily be included in a tax expenditure budget. Disclosing by name of corporation the amount that it benefits from a federal provision that is adopted by state law is a necessary first step in identifying which provisions should be subject to a cost benefit analysis. In each state, tax policy analysts, legislators and their staff, and tax administrators should be able to identify which provisions in the corporate income tax should be covered by a disclosure law.

Many states allow corporations to claim additional deductions in moving from federal taxable income to state taxable income. The more significant of these should also be subject to disclosure.

After calculating state taxable income, a corporation typically apportions that amount to a state using an apportionment formula. The formula usually takes into account the percentage of a corporation's property, payroll and receipts attributable to the taxing state. The components of this formula are useful for identifying both tax avoidance techniques and long-run trends and should also be part of the information disclosed.

For example, major corporations that have a low in-state receipts factor may highlight a need for a state to examine the adoption of a throw back or a throw out rule. 
Further, an abrupt change in a property or payroll factor involving a corporation that is known not to have changed its operations significantly may also suggest the use of tax avoidance techniques warranting further analysis. Data such as gross receipts, gross sales, or gross profits can also be useful in identifying transfer pricing abuses. ${ }^{337}$ In order to further help identify possible transfer pricing problems, corporations should disclose the names of any related corporations with which they have had any transactions and the nature and extent of those transactions.

Specialized industries, such as insurance and banks, are typically subject to special tax regimes. In many states, insurance companies are subject to a tax on their premiums rather than an income tax. Items subject to disclosure will thus differ in these cases from what is required of general business corporations.

Finally, corporations should have the right to explain any of the disclosed information in further detail.

\section{The Mechanics of Disclosure}

Little is gained from procedures that require the public to request affirmatively information from a state on specific corporations. Instead, a state should publish whatever information is subject to disclosure in a readily usable format.

If the information subject to disclosure is limited to items found on the return, the tax department would be the logical agency to administer the law. Presumably, the information would already be keypunched into computers for use in audit selection. This information could be printed out in a standard format and made available to the public.

A possible problem with this approach is whether it would violate a section of the Internal Revenue
Code that establishes safeguards that a state must impose as a precondition to obtaining federal returns or return information from the IRS. A violation of this section would be serious because most states have entered into an exchange of information program with the IRS, which provides them with valuable audit leads. Specifically, a state cannot require a taxpayer to "attach to, or include in, any State tax return a copy of any portion of his Federal return, or information reflected on such Federal return,
Corporations should have the right to explain any of the disclosed information in further detail.

A state should publish whatever information is subject to disclosure in a readily usable format. 
In an informal opinion, the IRS told the staff of the Massachusetts Special Commission on Business Tax Policy that as long as the Secretary of State's office obtains the disclosed data from reports filed with it by corporations, which is what the Massachusetts law provides, there would be no violation of the statute.

The current privacy provisions of the U.S. Internal Revenue Code were adopted in the aftermath of the Watergate-era abuses of the tax returns of individuals and non-profit organizations that were perceived to be subversive. unless such State adopts provisions of law which protect the confidentiality of the copy of the Federal return (or portion thereof) attached to, or the Federal return information reflected on, such State tax return." The question that arises is how to interpret this provision if a state law requires the disclosure of information contained on the federal return, such as federal taxable income.

In an informal opinion, the IRS told the staff of the Massachusetts Special Commission on Business Tax Policy that as long as the Secretary of State's office obtains the disclosed data from reports filed with it by corporations, which is what the Massachusetts law provides, there would be no violation of the statute. The informal view of the IRS is that it has entered into an information sharing agreement with the Massachusetts Department of Revenue, which has no role in the preparation of the taxpayer-specific reports that are disclosed. Under the Massachusetts disclosure law, the Department of Revenue would be honoring the agreements so that no violation would exist. ${ }^{339}$ The Massachusetts Commissioner of Revenue independently reached the same conclusion. ${ }^{340}$

Although their opinions appear to be a technical interpretation of the statute, both the Massachusetts Commissioner of Revenue and the IRS reach the right answer. The section of the Code at issue was introduced in the aftermath of Watergate. The abuse of income tax returns during Watergate focused on individual returns and those of nonprofit organizations, rather than on corporate returns. For example, the House Internal Security Committee examined the tax returns of Students for a Democratic Society, the Black Panther Party, the New Mobilization Committee to End the War in Vietnam, the Progressive Labor Party and the returns of officers of these groups. Other government agencies made extensive use of individual returns. The Senate Committee on Government Operations used tax returns for investigations of riots, civil and criminal disorders and campus disturbances. ${ }^{341}$ The Civil Service Commission used tax-return data to investigate job seekers; the Veterans Administration used returns to check the income of pension claimants; the Federal Housing Administration looked into the eligibility of families for housing assistance by inspecting their income tax returns. Income tax returns were also examined by the Federal Communications Commission in ferreting out "payola" taken by disc jockeys and the Federal Home Loan Bank Board used returns to determine whether activities of savings and loan associations and their staffs violated federal laws. The Securities and Exchange Commission was a regular user of tax returns in its surveillance of stockbrokers. The Small Business Administration used tax data to decide on the merits of loan applicants and to assist in pressing for loan repayments. Apparently, the biggest user of returns for routine law enforcement purposes was the Social Security Administration. The biggest users for investigative projects were the Justice Department and U.S. Attorneys, who had easy access to tax returns. It was reported that U.S. Attorneys inspected more than 18,000 individual returns in $1974 .{ }^{342}$

Because the Watergate abuses centered on individuals and not corporations, it seems reasonable to read the relevant section of the Code as being limited to individuals. ${ }^{343}$ Also, because a corporation's federal taxable income can be inferred from information contained in the Form $10-\mathrm{K}$ and in annual reports, there is no need for an overly broad reading of the statute.

Moreover, suppose a state instead of passing a law that requires a 
corporation to use federal taxable income as its starting point, which is a common approach, actually adopted as state law all of the federal provisions that enter into the calculation of federal taxable income but called this amount "state taxable income." Suppose that the state now required disclosure of that amount. It is hard to understand why that state should be denied the benefits of the IRS exchange of information program because it chose to disclose the amount of a corporation's state taxable income. Why should a different result be reached just because a state chooses to avoid the cumbersome process of explicitly adopting all of the federal provisions that impact on the definition of taxable income and incorporates them by reference?

This last point supports not only the informal opinion of the IRS regarding the Massachusetts disclosure law, but also supports the position that no violation of the Code would result even if a tax department were the agency that administered a disclosure law. Any doubts on this matter could be resolved through an official pronouncement by the IRS or through an amendment to the Code. Alternatively, the entire issue could be avoided if the SEC were to mandate the disclosure of more detailed information on state income taxes.

If the informal opinion of the IRS regarding the Massachusetts law reflects official policy, a state will avoid violating the Code by following the Massachusetts approach of having a corporation submit the required information to the Secretary of State (or some other person not involved with the tax department). If a state chooses to disclose information that the tax department would not normally have because it does not appear on the return, little loss in administrative efficiency would result if a corporation submits its information directly to the Secretary of State.

The real advantage in having the tax department involved arises from the assurance that the information being released is the same information appearing on the returns that were filed. If the tax department is not involved in the process, adequate safeguards have to be provided to both ensure that all corporations covered by the law actually file with the Secretary of

Because the Watergate abuses centered on individuals and not corporations, it seems reasonable to read the relevant section of the Code as being limited to individuals.

If the informal opinion of the IRS regarding the Massachusetts law reflects official policy, a state will avoid violating the Internal Revenue Code, by following the Massachusetts approach of having a corporation submit the required information to the Secretary of State (or some other person not involved with the tax department) should be followed.
The real advantage in having the tax department involved arises from the assurance that the information being released is the same information appearing on the returns that were filed. 
Verifying the data released would be particularly difficult if a state adopted a system of anonymous disclosure, in which a corporation is not identified by name but only by a number.
State, and that the information submitted is accurate. For example, a certified pubic accountant should be required to attest to the accuracy of the information reported. In addition, a list of publicly-traded corporations doing business in the state, as well as other entities subject to disclosure should be published so that it could be cross-checked against those filing with the Secretary of State. Verifying the data released would be particularly difficult if a state adopted a system of anonymous disclosure, ${ }^{344}$ in which a corporation is not identified by name but only by a number. 


\section{Conclusion}

The current debate over the disclosure of state corporate tax data has very deep roots. At the national level, starting with the Civil War income taxes, there was a robust debate over the extent to which the public should have access to federal tax information of both individuals and corporations. This debate, however, primarily centered on individuals and their rights of privacy rather than on large corporations; when corporations entered the discussion at all, it was typically in terms of concern for the privacy of "mom and pop" operations that could be viewed as the alter ego's of their owners. The few times when Congress concentrated on the differences between individuals and corporations, it recognized that legitimate reasons existed for granting more public access to corporate data than to individual data.

The SEC has essentially resolved the federal debate by imposing extensive financial reporting responsibilities on publicly-traded corporations, including the release of detailed information on federal income taxes and the aggregate amount of state income taxes. Proposals for state-disclosure would require that the state income tax information be disaggregated and presented in greater detail. These proposals are intended to facilitate thoughtful tax policymaking and more accountability and openness in government. They would also complement the SEC-mandated disclosure.

Compared with the much more extensive reporting requirements already imposed on corporations by other federal and state statutes and with the amount of financial information now in the public domain, proposals for state level disclosure are clearly unexceptional in terms of both the administrative burden involved and the type of data covered. The virtues of disclosure were graphically demonstrated by the efforts of Citizens for Tax Justice (CTJ) at the federal level, which resulted in many of the corporate tax changes in the Tax Reform Act of 1986. Perhaps it is the fears of those who are benefitting from the flaws in the current corporate tax system, more than any inherent defect in the proposals, which explain the contentious opposition of elements of the business community in Massachusetts, the one state that has adopted a comprehensive approach to state tax disclosure. In theory, the business community, as a whole, should be supportive of attempts to improve and rationalize government policymaking.

Most of the arguments against disclosure, similar to the arguments often raised against proposals that threaten the status quo, involve the incantation of threadbare and shopworn slogans. Others are based on speculation and unsupported assertions. While some opponents are undoubtedly sincere in their fears, their arguments fall well short of rebutting the benefits that would accompany disclosure. 


\section{ENDNOTES}

A version of this paper will be published in a forthcoming issue of the Capital Law Review.

1. CTJ, Corporate Income Taxes in the Reagan Years (1984).

2. N.Y. Times, Mar. 27, 1985, p. D1.

3. CTJ has been given credit for playing a key role in the passage of the 1986 Tax Reform Act. See, e.g., Birnbaum and Murray, Showdown at Gucci Gulch (1987), pp. 11-13, 88. For a fuller description of CTJ's work, see infra note 186 and accompanying text.

For an example of the support of major sectors of the business community of the 1986 changes, see Statement of Harry Sullivan, on behalf of the Tax Reform Action Coalition (TRAC) before the Committee on Ways and Means, House of Representatives on The Impact, Effectiveness and Fairness of the Tax Reform Act of 1986 (Feb. 7, 1990).

4. See infra note 184 and accompanying text.

5. See infra Sec. III(D).

6. N.Y. Legislative Commission on the Modernization and Simplification of Tax Administration and the Tax Law, Public Disclosure of Corporate Tax Information (1987). In the interest of disclosure, readers should know that the author was Director of the N.Y. Commission.

7. See infra Secs. III(A), (B), and (C).

8. See, e.g., Ala. Code $\S 40-2 A-10$ (Supp. 1992); Alaska Stat. § 43.05 .230 (1990); Ariz. Rev. Stat. Ann. § 42-108 (1991 \& Supp. 1992); Cal. Rev. \& Tax. Code § 19282 (West 1983); Colo. Rev. Stat. § 39-21-113 (1982 \& Supp. 1992); Conn. Gen. Stat. Ann. § 12-15 (West 1983 \& Supp. 1993); Del. Code Ann. tit. 30, § 368 (Supp. 1992); Fla. Stat. Ann. § 213.053 (West 1989 \& Supp. 1993); Ga. Code Ann. § 48-7-60 (Harrison 1990); Haw. Rev. Stat. § 235-116 (1985); Idaho Code $\S 63-3076$ (1989); Ill. Rev. Stat. ch. 35, para. 5/917 (1993); Ind. Code § 6-8.1-7-1 (1991 \& Supp. 1992); Iowa Code Ann. § 422.20 (West 1990 \& Supp. 1993); Kan. Stat. Ann. § 79-3234 (1989 \& Supp. 1992); Ky. Rev. Stat. Ann. § 131.081 (Baldwin 1987); La. Rev. Stat. Ann. § 47:1508 (West 1990); Me. Rev. Stat. Ann. tit. 36, § 191 (West 1990 \& Supp. 1992); Md. Tax-Gen. Code Ann. § 13-202 (1988); Mich. Stat. Ann. § 7.559(4) (Callaghan Supp. 1992-1993); Minn. Stat. Ann. § 290.611 (West 1989 \& Supp. 1993); Miss. Code Ann. § 27-783 (1991); Mo. Rev. Stat. § 32.057 (1991); Mont. Code Ann. § 15-31-507 (1991); Neb. Rev. Stat. § 77-27,119(6) (Supp. 1992); Nev. Rev. Stat. Ann. § 364A.100 (Michie Supp. 1991); N.H. Rev. Stat. Ann. § 77.19 (1991); N.J. Stat. Ann. § 54:50-8 (West 1986 \& Supp. 1993); N.M Stat. Ann. § 7-1-8 (Michie Supp. 1992); N.Y. Tax Law § 202 (McKinney 1986 \& Supp. 1993); N.C. Gen. Stat. § 105-259 (1992); N.D. Cent. Code § 57-38-57 (1983 \& Supp. 1991); Ohio Rev. Code Ann. § 5747.18 (Anderson 1991); Okla. Stat. Ann. tit. 68, § 205 (West 1992); Or. Rev. Stat. § 314.835 (1993); Pa. Stat. Ann. tit. 72, § 7408(b) (1990); R.I. Gen. Laws § 4411-21 (1988); S.C. Code Ann. § 12-7-1680 (Law. Co-op. 1977 \& Supp. 1992); S.D. Codified laws Ann. § 10-1-28.3 (1989); Tenn. Code Ann. § 67-2-108 (1989); Texas Ann. Stat. § 171.206; Utah Code Ann. § 59-1-403 (1992); Vt. Stat. Ann. tit. 32, § 3102 (Supp. 1992); Va. Code Ann. § 2.1-342 (Michie 1987).

9. As of May, 1993, five states have discussed corporate tax disclosure laws. See Corporate Tax Disclosure: Good or Bad for the Commonwealth, Draft Working Report, May 28, 1993, App. A (hereinafter cited as Massachusetts Staff Draft). For a discussion of this report, see infra note 193 and accompanying text. 
10. See infra. Sec. II(H).

11. See, e.g., N.Y. Times, October 24, 1924, p.1.

12. See Int. Rev. Code of 1986, Secs. 6103(e)(1)(D)(iii); 6103(a)(3).

13. Act of Aug. 5, 1861, Ch. 45; 12 Stat. 292, 309 (1861).

14. Id. Sec. 49 (emphasis added).

15. Accord, Hubbard v. Blair, T.D. 3661, 27 Treas. Decisions Int. Rev. 4 (1925). The Congressional Research Service claims that the original Civil War income tax statute "did not contain a statement on the publicity of income tax data," but this assertion is belied by the statutory language quoted in the text accompanying supra note 14. Congressional Research Service, History Of Tax Return Confidentiality: Section 6103 of the Internal Revenue Code of 1954 and its Predecessors (hereinafter Return Confidentiality), p. 3.

16. The 1861 tax was regarded as essentially provisional and Secretary of the Treasury Chase did not attempt to collect it. Ratner, Taxation and Democracy in America (1967), p. 68.

17. Act of July 1, 1862, Ch. 119; 12 Stat. 432 (1862).

18. "And be it further enacted, That the assessors for each collection district shall, by advertisement in some public newspaper published in each county within said district, if any such there be, and by written or printed notifications, to be posted up in at least four public places within each assessment district, advertise all persons concerned of the time and place within said county when and where the lists, valuations, and enumerations made and taken within said county may be examined; and said lists shall remain open for examination for the space of fifteen days after notice shall have been given as aforesaid." Act of July 1, 1862, Ch. 119, Sec. 14; 12 Stat. 432, 437 (1862).

19. Act of July 1, 1862, Ch. 119; 12 Stat. 439. The Act of 1862 authorized the President to divide the country into "convenient collection districts," and to appoint with the advice and consent of the Senate an assessor and collector for each collection district. The assessor was charged with the duty of locating objects of taxation and preparing assessment lists to be delivered to the collector. These lists constituted the warrant of the collector for the collection of assessable taxes. Those subject to the income tax were required to file an annual return with the assistant assessor. The assessor heard all appeals and issued summons to delinquents. History of the Internal Revenue Service: 1791-1929 (prepared under the direction of the Commissioner of Internal Revenue, 1930), pp. 3-4.

20. Return Confidentiality, supra note 15, p. 4. ("The imposition of this provision for advertisement of assessor's lists, therefore, appears to have been intended to publicize the tax assessment of each citizen, and to communicate to each citizen his lawful obligation to pay.")

21. Congressional Globe, March 17, 1862, p. 1259

22. Report on Administrative Procedures of the Internal Revenue Service to the Administrative Conference of the United States, S. Doc. 94-266, 94th Cong., 2d Sess. 835 (1975) (hereinafter Administrative Procedures), p. 835.

23. Return Confidentiality, supra note 15, p. 5. Administrative Procedures, supra note 22, p. 835.

24. Administrative Procedures, supra note 22, p. 835. 
25. Smith, The United States Federal Internal Tax History from 1861 to 1871 (1914), p. 66.

26. See id. p. 67. See Also Boutwell, A Manual on the Direct and Excise Tax System of the United States (1864), p. 259.

27. Secretary of the Treasury, 38th Cong., 1st Sess., Report of the Secretary of the Treasury on the State of the Finances for the Year Ending June 30, 1863 (1863), p. 70.

28. Act of June 30, 1864, Ch. 173, Sec. 19; 13 Stat. 218, 228 (1864). "[I]t shall be the duty of the assessor for each collection district, at the time fixed for hearing such appeal, as aforesaid, to submit the proceedings of the assessors and assistant assessors, and the annual lists taken and returned as aforesaid, to the inspection of any and all persons who may apply for that purpose". Apparently, the law intended that only the name, income, and taxes paid were to be open for public inspection, but not the underlying data. See also Internal Revenue Recorder and Excise Journal, Jan. 7, 1865.

29. See, e.g., New York Tribune, Jan. 20, 1865, p. 5.

30. New York Times, Dec. 29, 1864, p. 4.

31. New York Tribune, Jan. 21, 1865, p. 4.

32. Smith, supra note 25, p. 67.

33. Commercial and Financial Chronicle, vol 2., p. 162, Feb. 10, 1866. This position was consistent with the New York Times assertion that disclosure had generated millions of dollars, although presumably the Times was not attributing this figure to taxpayers who filed false returns reporting more income than they actually had.

34. See, e.g., New York Tribune, Jan. 20, 1865, p. 5; see also K. Kennan, Income Taxation: Methods and Results in Various Countries (1910), p. 251 n.16; Smith, supra note 25, pp. 6668; Hill, The Civil War Income Tax, 8 Quarterly Journal of Economics. 425, 436 (1894).

35. Cited in Janssen, Income Tax Snooping Through History, Wall St. J., May 6, 1970, p. 18.

36. New York Times, July 9, 1866, p. 4 (emphasis in original).

37. Congressional Globe, May 23, 1866, p. 2789.

38. Return Confidentiality, supra note 15, p. 6.

39. Congressional Globe, May 23, 1866, p. 2789.

40. See, e.g., Administrative Procedures, supra note 22, p. 837.

41. See, e.g., New York Times, July 26, 1869, p. 4.

42. New York Times, Aug. 7, 1869, p. 4.

43. Administrative Procedures, supra note 22, p. 839.

44. Janssen, supra note 35 .

45. Act of July 14, 1870, Ch. 255, Sec. 11; 16 Stat. 256, 259 (1870). "[N]o collector, deputy collector, assessor, or assistant assessor shall permit to be published in any manner such income returns, or any part thereof, except such general statistics, not specifying the names of 
individuals or firms, as he may make public, under such rules and regulations as the commissioner of internal revenue shall prescribe." The literature is silent on how this provision was to be interpreted. Presumably, because the income tax expired shortly after the passage of this law, there was not enough time or reason for such questions to arise.

46. Administrative Procedures, supra note 22, p. 838. See also Smith, supra note 25, p. 68 ("[M]uch of the opposition to the tax would never have been raised if it had not been felt that [publicity] was an unnecessary exposure of private affairs. It is very questionable whether the benefit received from publicity was not entirely offset by the injury it did, because of the antagonism to the tax which it aroused"). Garfield also described the publicity features as making the tax "odious in many parts of the country." See Seligman, The Income Tax: A Study of the History, Theory, and Practice of Income Taxation at Home and Abroad (1914), p. 452 .

47. By virtue of an administrative directive of the Commissioner, the 1862 Act was interpreted to exclude firms of any sort from taxation. S. Ratner, supra note 16, p. 76 n.41. The Act imposed the tax on the "annual gains, profits, or income of every person residing in the United States, whether derived from any kind of property, rents, interest, dividends, salaries, or from any profession, trade employment, or vocation carried on in the United States or elsewhere. .." Act of July 1, 1862, Ch. 119, Sec. 89; 12 Stat. 432, 473. If the word "person" is read to include entities as well as individuals, which would be today's usage, see Internal Revenue Code of 1986, Sec. 7701(a)(1), the 1862 tax would apply to corporations. Elsewhere in the statute, however, "person" is used to refer to only individuals. See, e.g., Ch. 119, Sec. 93; 12 Stat. 475 ("persons of lawful age"). In any event, by 1864, the law was clarified. The 1864 Act provided that income was to include the share of any person of the gains or profits, whether divided or not, of all companies or partnerships, which suggests that it was the shareholder and not the corporation that was intended to be taxed on corporate profits. See Act of June 30, 1864, Ch. 173, Sec. 116; 13 Stat. 282. The author has been unable to find any discussion about the administrative burdens arising from this early approach to integration.

48. Act of Aug. 27, 1894, Ch. 349; 28 Stat. 509 (1894).

49. Act of Aug. 27, 1894, Ch. 349, Sec. 34; 28 Stat. 509, 557-558 (1894). "[I]t shall be unlawful for any collector, deputy collector, agent, clerk, or other officer or employee of the United States to divulge or to make known in any manner whatever not provided by law to any person the operations, style of work or apparatus of any manufacturer or producer visited by him in the discharge of his official duties, or the amount or source of income, profits, losses, expenditures, or any particular thereof, set forth or disclosed in any income return by any person or corporation, or to permit any income return or copy thereof or any book containing any abstract or particulars thereof, to be seen or examined by any person except as provided by law; and it shall be unlawful for any person to print or publish in any manner whatever not provided by law, any income return or any part thereof, or the amount or source of income, profits, losses, or expenditures appearing in any income return; and any offense against the foregoing provision shall be a misdemeanor and be punished by a fine not exceeding one thousand dollars or by imprisonment not exceeding one year, or both, at the discretion of the court; and if the offender be an officer or employee of the United States he shall be dismissed from office and be incapable thereafter of holding any office under the Government."

The reference to divulging the operations, style of work, or apparatus of any manufacturer or producer was originally adopted in the Act of June 30, 1864, see Sec. 38; and was later codified in R.S. 3167. In 1864, there was no reference to the disclosure of income tax returns. That language was added as part of the 1894 income tax.

50. Return Confidentiality, supra note 15 , at 10.

51. Pollock v. Farmer's Loan and Trust Co., 157 U.S. 429 (1895). 
52. See letter of Representative Cordell Hull (D-Tennessee), Congressional Record, Sept. 10, 1918, p. 10168; Janssen, supra note 35, p. 18.

53. See supra note 47.

54. Act of Aug. 27, 1894, Ch. 349; 28 Stat. 509 (1894).

55. Act of Aug. 5, 1909, Ch. 6; 36 Stat. 11 (1909).

56. Act of Aug. 5, 1909, Ch. 6, Sec. 38, Sixth; 36 Stat. 11, 116 (1909).

57. Return Confidentiality, supra note 15, p. 10.

58. Administrative Procedures, supra note 22, p. 840.

59. Congressional Record, July 1, 1909, p. 4001.59.

60. Id. pp. 4001-02.

61. Id. p. 4002.

62. Id. p. 4006.

63. Robinson, The Federal Corporation Tax, 1 American Economic Review 691, 707-08 (1911); see especially S. Doc. 61-98, 61st Cong., 1st Sess. (1909). Ironically, when the law was changed in 1924 to permit the publication of the names of both individuals and corporations and the amount of taxes paid, see Part E infra, the New York Times trumpeted the amount paid by Charles Taft, the former President's brother (at the time of publication, former President Taft was Chief Justice of the Supreme Court). See New York Times, Oct. 25, 1925, p. 2.

64. Taft and Roosevelt: The Intimate Letters of Archie Butt, Military Aide, vol. 1, 1930, pp. 262-63.

65. Robinson, supra note 63, p. 708. These groups had a friend in Franklin MacVeagh, President Taft's Secretary of the Treasury, who said that if he were subject to the disclosure law, he would do all he could "to evade the law." Ratner, supra note 16, p. 295. "The amazing statement made by MacVeagh as a responsible government official was surpassed by the campaign of invective against the tax released by businessmen." Id.

66. Ratner, supra note 16, p. 295.

67. To be sure, this discrimination could have been eliminated by providing that individual returns should also be open to inspection, but this was not part of the Association's agenda. There are, however, legitimate reasons for distinguishing between corporations and individuals, see Section IV(F) and V(A), infra. Removing individuals from the ambit of disclosure recognizes that they have more legitimate rights of privacy than do corporations. If individuals are not covered, opponents of corporate disclosure can disingenuously assert that corporations are being unfairly treated; such opponents are not interested in extending disclosure to individuals but only in scuttling disclosure for corporations.

68. T.D. 1594, 13 Treas. Decision Int. Rev. 20 (1910).

69. Robinson, supra note 63, pp. 708-09. The 1909 Act was challenged as unconstitutional. According to one commentator, the publicity features, which were considered to be a very 
important feature of the bill, were not enforced until the Act was upheld in Flint v. Stone Tracy Company, 220 U.S. 107 (1911). Kennan, supra note 34, p. 286. The Court upheld the Act, inter alia, against charges that the inspection of corporate returns violated the Fourth Amendment.

70. Act of June 17, 1910, Chap. 297; 36 Stat. 468, 494.

71. Id.

72. Administrative Procedures, supra note 22, p. 841.

73. Congressional Record, April 1, 1910, pp. 4131-35.

74. T.D. 1665, 13 Treas. Decision Int. Rev. 117 (1910).

75. Id.

76. See supra note 49 .

77. Act of Oct. 3, 1913, Ch. 16, Sec. II(G)(d); 38 Stat. 114, 177 (1913). The Act also provided that "proper officers of any State imposing a general income tax may, upon the request of the governor thereof, have access to said returns or to an abstract thereof, showing the name and income of each such corporation ... at such times and in such manner as the Secretary of the Treasury may prescribe. 38 Stat. 177 (1913). Seligman attributes this provision to LaFollette, the Progressive Senator from Wisconsin. Seligman's explanation seems reasonable; LaFollette was an avid supporter of disclosure and Wisconsin was the only state to have an income tax at this time. Seligman, supra note 46, p. 699.

78. Administrative Procedures, supra note 22, p. 844. The 1910 regulations concerning access to corporate returns, see supra note 77 and accompanying text, were reissued. See T.D. 2016, Aug. 18, 1914. One difference was that the 1913 regulations allowed a corporation the opportunity to state whether any legitimate reason existed for refusing permission to the shareholder seeking to inspect the return.

79. See, e.g., Congressional Record, November 5, 1921, pp. 7365-74; November 7, 1921, pp. 7518-19.

80. Tax Act of 1918, Ch. 18, Sec. 257; 40 Stat. 1086.

81. Tax Act of 1918, Ch. 18, Sec. 257; 40 Stat. 1086. Such shareholders could examine even the returns of years prior to the time that they became shareholders provided that ownership of $1 \%$ or more of the outstanding stock existed at the time of the request for inspection. I.T. 1648, C.B. II-1, 186 (1923). Conversely, former shareholders are not allowed to inspect the return of the corporation for any year. Id. There was no statutory provision for examining a consolidated return by a stockholder in one of the subsidiary companies. I.T. 1588, C.B. II-1, 184. A shareholder's privilege to inspect was personal and could not be delegated to another. Reg. 74, Art. 424; Reg. 69, Art. 1093; Reg. 65, Art. 1094; Art. 1093, Regs. 62 and 45.

82. Tax Act of 1918, Ch. 18, Sec. 257; 40 Stat. 1086. See supra note 49.

83. See supra note 74 and accompanying text. These regulations were eliminated in 1920. See T.D. 2961, 22 Treas. Decision Int. Rev. 3 (1920).

84. See I.R.C. Sec. 6103(e)(1)(D)(iii). In 1921, the LaFollette bloc in Congress unsuccessfully attempted to change the law to require the publication of returns, but the bill was defeated in the Senate 28-34. The votes in favor all came from the farm bloc (Kansas, 
Washington, Iowa, Oregon, South Dakota, and Nebraska), joined by LaFollette. The votes in opposition were all Republicans. The Independent, Nov. 8, 1924, p. 353. After this bill was defeated, LaFollette unsuccessfully tried to make the amount of income declared by each taxpayer open for inspection. Congressional Record, November 5, 1921, pp. 7365-74; November 7, 1921, pp. 7518-19.

85. Leff, The Limits of Symbolic Reform: The New Deal and Taxation, 1933-1939 (1984), p. 67.

86. Act of June 2, 1924, Ch. 234, Sec. 257(b); 43 Stat. 293 (1924) ("The Commissioner shall as soon as practicable in each year cause to be prepared and made available to public inspection in such manner as he may determine, in the office of the collector in each internalrevenue district and in such other places as he may determine, lists containing the name and the post-office address of each person making an income-tax return in such district, together with the amount of the income tax paid by such person.") The House bill permitted public inspection only under rules prescribed by the Secretary and approved by the President. The Senate bill provided for complete disclosure. Blakey and Blakey, The Federal Income Tax (1940), p. 245.

In 1924, the law also expanded state access to federal corporate income tax returns. "The proper officers of any State may, upon the request of the governor thereof, have access to the returns of any corporation, or to an abstract thereof showing the name and income of the corporation, at such times and in such manner as the Secretary may prescribe." Act of June 2, 1924, Ch. 234, Sec. 257(a); 43 Stat. 293 (1924). Previously, such access on the part of state officers was limited to those states which levied an income tax. See supra note 77 and accompanying text.

The 1924 Act was upheld against attacks that it violated an individual's right to privacy and the right to be secure in his or her personal effects and papers. Hubbard v. Mellon, 5 F. $2 \mathrm{~d} 764$ (1925).

87. Congressional Record, February 15, 1924, p. 2512; February 22,1924, pp. 2952-60, debate on amendment by Representative James Frear (R-Wisconsin). The Progressives apparently did not view the 1924 Act as a victory but rather a defeat for their position of making returns open to inspection. Congressional Record, May 18, 1928, p. 9078; May 25, 1928, p. 9851;....pp. 9403-05.

88. See The Saturday Evening Post, December 20, 1924, p. 20.

89. The Literary Digest, March 8, 1924, p. 12.

90. Administrative Procedures, supra note 22, p. 843.

91. Secretary of Commerce Herbert Hoover issued a statement that the publicity of returns caused much harm to business, especially to the small trader, because competitors found out much valuable information. He characterized the publicity of returns that existed from 1867 to 1872 as contributing to the industrial and financial chaos of those times. Id. p. 245 n. 95. Presumably, he meant 1867 to 1870; publication was abolished in 1870. See supra note 45 and accompanying text.

92. Ratner, supra note 16, p. 427.

93. Blakey and Blakey, supra note 86, p. 246.

94. The Current of Opinion, Dec. 1924, p. 686.

95. Leff, supra note 85, p. 67. 
96. See, e.g. N.Y. Times, Sept. 2, 1925, p. 1; Sept. 3, 1925, p. 1; Sept. 4, 1925, p. 1.

97. Apparently, a similar book exists in Sweden where the official assessment lists, showing the amounts of assessable income as determined by the assessment boards, are public documents. See infra note 177.

98. U.S. v. Dickey, 268 U.S. 378 (1925)(holding that R.S. Sec. 3167, making it "unlawful for any person to print or publish in any manner whatever not provided by law, any income return or any part thereof" did not apply to the publicity provisions of the 1924 Act.); U.S. v.

Baltimore Post, 268 U.S. 388 (1925).

99. New Republic, Nov. 12, 1924, p. 262.

100. Id. p. 263.

101. The Current of Opinion, Dec. 1924, p. 687.

102. New York Times, Sept. 2, 1925, p. 1.

103. New York Times, Sept. 3, 1925, p. 1. The Times suggested that the individuals probably had investments in tax-exempt securities, "among other factors." Id.

104. The Current of Opinion, Dec. 1924, p. 687.

105. The Independent, November 8, 1924, p. 353.

106. Id. p. 354.

107. Saturday Evening Post, supra note 88.

108. Current of Opinion, supra note 94, p. 687.

109. New York Times, Sept. 3, 1925, p. 1.

110. Id. p. 2

111. Id.

112. Id. p. 1. According to the Treasury, "there is no excuse for the present publicity provisions except the gratification of idle curiosity and the filling of newspaper space." Revenue Revision, 1925: Hearings Before the House Ways and Means Comm., 69th Cong., 1st Sess. (1925), pp.8-9.

113. The roots of Mellon's opposition may have been personal. He could not have been pleased when the New York Times trumpeted that he paid $\$ 1,173,987$ in income tax, the largest of any individual in the Pittsburgh district. The headline of the same article went on to mention that his brother paid \$348,646 and a nephew paid \$225,834. New York Times, Oct. 25, 1924, p. 2.

114. Hearings, supra note 112, pp. 65-66, 278-79, 280-83.

115. Act of Feb. 26, 1926, Ch. 27, Sec. 257(e); 44 Stat. 9, 52 ("The Commissioner shall as soon as practicable in each year cause to be prepared and made available to public inspection in such manner as he may determine, in the office of the collector in each internal-revenue district and in such other places as he may determine, lists containing the name and the postoffice address of each person making an income-tax return in such district"). 
As of 1926, the rules governing access by private individuals to non-corporate returns were as follows. Individual returns were open to inspection by the person who made the return, their duly constituted attorney in fact, a receiver in bankruptcy, guardian, or similar legal custodian. I.T. 2087, Cum. Bull. III-2, 328 (1924); In re Epstein, 300 Fed. 407; S. M. 2353, Cum. Bull. III-2, 327 (1924); reg. 74, Art. 422. If the maker of the return had died, the administrator, executor, or trustee of his or her state was entitled to inspect the return. The Commissioner had the discretion to open the return to any heir at law or next of kin of a deceased person or to the duly constituted attorney in fact for such person upon a showing that the heir or kin had a material interest which may be effected by information contained in the return. Reg. 62, Art. 1091, Par. 8 (c); Reg. 69, Art. 1090, Par. 8 (b); Reg. 74, Art. 421. Either spouse filing a joint return had the privilege to inspect it; in the event of the death of either spouse, the inspection privilege was available to the survivor or the personal representative of the decedent or duly appointed attorney in fact of the survivor. The Commissioner had the discretion to allow any heir at law or next of kin of the deceased spouse to inspect the return upon a showing of a material interest in the return. S.M. 1992, Cum. Bull. III-2, 327 (1924). Similar rules applied in the case of partnership returns. Any member of a partnership during any part of the time covered by the return could inspect it as well as representatives or next of kin of a deceased partner provided they had a material interest effected by information in the return. Reg. 74, Art. 421; Art. 1090, Par. 7, Regs. 69, 65, and 62. Tax returns filed by or on behalf of an estate were subject to inspection by the administrator, executor, or trustee of such estate and, in the Commissioner's discretion, by any heir of law or next of kin of the decedent or by an attorney in fact for such persons upon evidence of a material interest that may be effected by information contained in the return. Reg. 74, Art. 421; Art. 1090, Par. 8, Reg. 69, 65 and 62 . In the case of trusts, the trustees, any individual who is a beneficiary of a trust during any part of the time covered by the return, administrators, executors, representatives of the estate of the deceased beneficiary of the trust or, in the discretion of the Commissioner, any heir at law or next of kin of such deceased beneficiary, also had access upon a showing of material interest which may be effected by information contained in the return. Reg. 74, Art. 421; Art. 1090, Par. 9, Regs. 69, 65, and 62. Regulations issued in 1931 expanded access to non-corporate tax returns by providing access by persons having a material interest in the taxpayer, for example, beneficiaries of estates and partners of a partnership. T.D. 4317, Cum. Bull., X-1, 146 (1931).

116. Ratner, supra note 16, p. 427.

117. In 1966, the provision was changed to provide information only on whether a person had filed an income tax return. P.L. 89-713, Sec. 4; 80 Stat. 1109. The change was made because of the difficulty of making microfilm (which was the medium used to store the data) available to the public and because of the desire to keep Social Security numbers confidential. S. Rep. No. 1625, 89th Cong., 2d Sess. (1966), pp.7-8.

118. Ratner, supra note 16 , pp. 427-8.

119. Quoted in Leff, supra note 85, pp. 67-68.

120. Id.

121. Id. LaFollette was chastised for attempting to link the controversial issue of tax publicity with the NIRA. Administrative Procedures, supra note 22, p. 1035 n. 45.

122. Id.

123. Congressional Record, April 13, 1934, p. 6554. LaFollette's proposal was adopted by a 41-34 vote. 
124. Act of May 10, 1934, Ch. 277, Sec. 55(b); 48 Stat. 680, 698 (1934). Apparently Representative Wright Patman (D-Texas) conceived the use of pink slips. Administrative Procedures, supra note 22, p. 853 n. 54. Similar to the earlier votes on publicizing income tax data, voting on the pink slips was along urban-rural lines. Except in highly urbanized states, a substantial majority of Democrats and most Republicans favored publicity. Although only one Northeasterner supported LaFollette's amendments, Midwestern Senators strongly supported him. The South split almost evenly because Democratic Party stalwarts opposed the amendments. Leff, supra note 85, p. 68 .

125. The pink slip provision was consistent with the New Deal's concern over the level of corporate salaries. During the depression, corporate executives were viewed by some as an "extraneous, unproductive layer that soaked up an extravagant share of the shrunken consumer dollar. The widely bruited gap between a corporation's dispersed ownership and its actual control cast corporate directors as a specially privileged, self-regulating group that selfishly hoarded outrageous salaries and bonuses." Leff, supra note 85, p. 74 (1984). Themes of sacrifice, fraud, frugality, and stockholder rights animated discussions over whether executive salaries should be limited. The compromise was to require corporations to include with their tax returns a list of names and total compensation of employees earning more than $\$ 15,000$. The Treasury submitted to Congress a cumulative list, which was then made public. Id. p. 77. Not surprisingly, the disclosure of salaries was also controversial:

We are told that because of this publicity these individuals will become the prey of racketeers, kidnapers and cranks. In considering the merits of such criticism it is well to bear in mind that in the past, the wealthy have been, broadly speaking, the only element in the community exempt from such information. The wages paid to workers in industry are nearly always a matter of public record. College professors' salaries are known, and are frequently printed in the catalogues. Employees of the federal government and of most of the states and cities receive stipends that are officially recorded. The American temperament being what it is, the income of almost anyone can be estimated within broad limits, from the scale on which he lives.

Making public the salaries paid by corporations performs a distinct public service; for example, the facts can be checked against the wages paid by the same corporation and against the customary plea of poverty when the workers ask an increase in those wages. As for the danger from racketeers and kidnapers, the first point to make is that these gentry do not need to wait for a government publication to help them select their potential victims; and in the second place, the answer in the long run is for the government to fight the underworld directly, and not by withholding possibly useful data.

New Republic, January 22, 1936, p. 299.

Opponents of this salary disclosure requirement failed to piggyback repeal of this provision onto the repeal of the pink slips, but in 1938 they succeeded in increasing the $\$ 15,000$ level to $\$ 75,000$. It was not until 1949 , when the Treasury testified that it considered the extraction of 1,000 names from 600,000 returns a waste of time, that the salary provision quietly died. Id. p. 80 .

126. Senator George W. Norris (R-Nebraska), Congressional Record, 74th Cong., May 27, 1935, p. 4511.

127. Senator Robert M. LaFollette, Jr. (PR-Wisconsin), Congressional Record, April 13, 1934, p. 6553.

128. Representative Wright Patman, Congressional Record, February 15, 1934, p. 2600.

129. Senator Robert M. LaFollette, Jr., Congressional Record, April 13, 1934, p. 6546; March 27, 1935, p. 4512.

130. Janssen, supra note 35. 
131. Saturday Evening Post, June 8, 1935, p. 44.

132. Leff, supra note 85, p. 72 .

133. Senator Marvel Logan (D-Kentucky), Congressional Record, March 27, 1935, p. 4506.

134. Representative Robert L. Bacon (R-New York), Congressional Record, February 20, 1935.

135. Leff, supra note 85, p. 70 .

136. Representative Robert L. Bacon, Congressional Record, February 27, 1935, p. 2690.

137. Supra note 134, p. 2307.

138. Id.

139. Representative Alfred Beiter, Congressional Record, February 25, 1935, p. 2594.

140. Representative Robert L. Bacon, Congressional Record, February 27, 1935, pp. 2687-81.

141. New York Times, Feb. 27, 1935, p. 5.

142. Saturday Evening Post, April 20, 1935, p. 26.

143. New Republic, March 20, 1935, p. 143.

144. Representative Adolph Sabath (D-Illinois), Congressional Record, March 11, 1935, p. 3391.

145. Representative Charles Truax (D-Ohio), Congressional Record, March 11, 1935, pp. 3392-93.

146. Speech of Representative Bacon, quoted in Return Confidentiality, supra note 15, p. 84 .

147. Letter dated Feb. 14, 1935, quoted in Return Confidentiality, supra note 15, p. 62.

148. Report From the Committee on Ways and Means on H.R. 6359, Repeal Certain Provisions Relating to Publicity of Certain Statements of Income, H.R. Report No. 313, 74th Cong., 1st Sess. (March 7, 1935).

149. Act of April 19, 1935, Ch. 74; 49 Stat. 158. The Saturday Evening Post described the repeal as scrapping "what promised to be a card-index system available to every kidnaper, blackmailer, blue-sky security salesmen, town gossip, gold digger, alimony hunter or other exploiter on the prowl for victims." Saturday Evening Post, June 8, 1935, p. 23.

150. House Report, supra note 148, p.1.

151. LaFollette is given credit for Wisconsin's law by the Independent, Nov. 8, 1924, p. 353.

152. House Report, supra note 148, p. 2.

153. Congressional Record, May 25, 1928, p. 9847.

154. House Report, supra note 148, p. 2. 
155. Representative Charles Gifford (R-Mass.), Congressional Record, March 8, 1938, p. 3058 .

156. Leff, supra note 85, p. 72 .

157. Id.

158. Id.

159. Congressional Record, March 11, 1935, pp. 3408-3411.

160. The vote in the House was 301-99 in favor of a motion to recommit the proposal. Republicans, who by 1935 enjoyed extraordinary cohesion, voted almost unanimously for repeal. All third-party Congressmen voted for disclosure, but rural Democrats split slightly against it and Southern Democrats--whose innate conservatism often surfaced when party loyalty was not involved--voted for repeal by a margin of almost two to one. Id. p. 3411. The division in the Senate was somewhat similar, except that Republicans from farm states divided evenly. No Northeasterners voted against repeal, which is not surprising because none had voted in favor of the pink slips. More striking was the erosion of support from rural conservative Democrats.

161. Access to tax returns by the non-public continued to absorb the attention of Congress. In 1936, for example, Congress permitted the inspection of individual as well as corporate income tax returns by state and local tax administrators. Tax Act of 1936, Subtitle A, Ch. 1 (Part V), Sec. 55 (b)(1); 49 Stat. 158. See I.R.C. Sec. 6103(b)(1). Previously, only corporate returns were available for inspection.

162. For an excellent history on these myriad of administrative guidelines on disclosure see Administrative Procedures, supra note 22, at 844-853.

163. Id. at 849.

164. 90 Stat. 1525 (1976).

165. See, Who's Snooping Into Your Tax Returns Now?, U.S. News \& World Rep., Aug. 11, 1975, at 61; See also, Confidentiality of Tax Return Information: Hearings Before the House Committee on Ways and Means, 94th Cong., 2d. Sess. (1976); I.R.S. Procedures: Hearings Before the Subcommittee on Oversight of the House Committee on Ways and Means, 94th Cong., 1st Sess. (1975); Freedom of Information: IRS: Hearings Before the Subcomm. on Administrative Practice and Procedure of the Senate Comm. on the Judiciary, 93rd Cong., 2d Sess. 1 (1974); I.R.C. Sec. 6103 (Supp. 1990).

166. Int. Rev. Code of 1986, Sec. 6103(a). The 1976 changes continued prior law, see supra note 81 and accompanying text, which permits any bona fide shareholder of record owning one percent or more of the outstanding stock of a corporation to inspect the return of such corporation or its subsidiary. I.R.C. Sec. 6103(e)(1)(D)(iii). The shareholder "shall not disclose any return or return information obtained by him." Id. Sec. 6103(9).

167. Cited in Zeff, 1926 to 1971 Chronology of Significant Developments in the Establishment of Accounting Principles in the United States, in Rappaport and Revsine, Corporate Financial Reporting: The Issues, The Objectives and Some New Proposals, p. 219 (1972) (hereinafter cited as Financial Reporting).

168. Saturday Review, April 13, 1963, p.76.

169. Financial Reporting, supra note 167, p. 220. 
170. 15 U.S.C. Secs. 77 a-77aa.

171. Financial Reporting, supra note 167, p. 220.

172. 15 U.S.C. Secs. $78 \mathrm{a}-78 \mathrm{hh}-1$.

173. Measurement standards refer to the methods by which assets, liabilities, ownership and profit and loss are disclosed. Horwitz and Kolodny, Financial Reporting Rules and Corporate Decisions: A Study of Public Policy (1982), p.15.

174. Id., p. 10.

175. Id.

176. In 1938, the SEC issued Accounting Series Release (ASR) 4, in which it stated that financial statements filed pursuant to its rules and regulations that were prepared in accordance with accounting practices for which there was no substantial authoritative support were presumed to be misleading, and that footnotes or other disclosures would not rebut this presumption. The American Institute of Accountants (AIA), the predecessor of the American Institute of Certified Public Accountants (AICPA), established a Committee on Accounting Procedure (CAP), which began to issue accounting research bulletins in 1939. The authority of the these bulletins was ambiguous because the CAP stated that the force of its opinions "rested upon their general acceptability." Horwitz and Kolodny, supra note 173, at 12.

The progress of the CAP was disappointingly slow and the AICPA then established the Accounting Principles Board (APB) in 1959. The APB was supposed to formulate GAAP. The APB, however, was also criticized for its slowness, as well as for the poor quality of its opinions. The credibility of the APB was weakened at an early stage in its history when the SEC refused to accept one of its opinions and forced the Board to reverse itself. Id., pp. 1213. As a result, the APB was replaced with the Financial Accounting Standards Board (FASB) in 1973. The FASB received a vote of confidence from the SEC in the same year in ASR 150. In ASR 150, the SEC stated that the principles, standards and practices promulgated by the FASB in its Statements and Interpretations will be considered as having substantial authoritative support, and contrary practices will be considered to have no such support. As the SEC said seven years later in ASR 280, "while there is, of course, always the possibility that the Commission may conclude it cannot accept an FASB standard in a particular area, such events have been rare."

177. All of the OECD countries (the Western democracies and Japan), and many other industrial and industrializing nations, have financial disclosure requirements as part of SECtype regulatory frameworks. Such countries also have their versions of generally accepted accounting principles as well as authoritative standard setting bodies such as FASB in the United States.

In the United Kingdom, for example, the Stock Exchange plays an extremely important role with respect to disclosure requirements. France (the Commission des Operations de Bourse), Italy (Commission Nazionale per le Societa e la Borsa) and Mexico (Comision Nacional de Valores) have a national commission, similar to the U.S. format, that enforces their securities laws. Japan has a Securities Bureau. In Canada, each province and territory has its own securities laws enforced by a local administrator. Australia has a National Companies and Securities Commission. In the Netherlands and Germany the stock exchanges are almost the exclusive source of securities regulation. Bloomenthal, International Capital Markets and Securities Regulation, Sec. 1.08[3](1982). For a detailed description of the elaborate Japanese rules, see Loss, Yazawa, Banoff, Japanese Securities Regulation (1983). Corporations are required to disclose a variety of financial data in these countries. For a description of the disclosure rules in various countries, see Bloomenthal, supra. In 1988, the Organization for Economic Co-Operation and Development (OECD) set forth a list of financial information, including income taxes, that should be disclosed in the published reports of multinational 
enterprises. OECD, Multinational Enterprises and Disclosure of Information: Clarification of the OECD Guidelines (1988). Financial reporting requirements, including the disclosure of income tax expenses, is also being examined on a comparative, cross national basis by two other important international organizations -- the International Accounting Standards Committee and the International Organization of Securities Commissions.

In addition to the disclosure of income tax information resulting from securities laws and accounting standards, several countries have additional forms of disclosure related to their customs and traditions. In Japan, for example, the national government publishes lists of companies that pay the largest amounts of taxes and most major firms apparently want to be mentioned. BNA, Daily Tax Reports, G-3 (Nov. 24, 1987).

Under the Swedish Freedom of the Press Act, the amount of corporate income taxes paid is a matter of public record, available for public examination at the tax administration. Telephone conversation with Mr. Lars Hollner, Swedish Embassy, Washington, D.C., Sept. 17, 1993. Since 1914, the "Taxeringskalender," a private publication, lists gross and taxable income for every Swedish citizen who qualifies. In 1985, for example, the edition for the Stockholm area included every individual who made more than $\$ 15,000$ a year and every couple who made $\$ 20,000$ or more. Forbes, Feb. 25, 1985, p. 130. (The Forbes article does not clarify whether the amounts refer to gross income or taxable income.) Anybody with $\$ 63,000$ or more in assets also made the list. In 1975, the publishers of Taxeringskalender started breaking down the list on a county-by-county basis, like telephone directories. Id. "It turns out the Swedes are such busybodies that the government doesn't need to offer a bounty for ratting on delinquent taxpayers, as the IRS does. In Sweden this happens anyway. Says a Swedish official, 'Sometimes a jealous neighbor will call tax officials and say, Please look into my neighbor, who has just bought a new Mercedes-Benz. They call that the royal Swedish envy."' Id.

Tax liabilities are also public information in Norway and are published by the newspapers. Telephone conversation with the Finance Officer, Norwegian Embassy, Nov. 2, 1993.

178. Accounting Series Release 149 (Nov. 28, 1973). For a detailed description, see infra note 184 and accompanying text.

179. Loss and Seligman, IV Securities Regulation 1856-57 (1990). For detailed background information, see BNA, Annual Reporting Under the Federal Securities Laws (1987 with 1992 supplement); Austin, Preparation of the Annual Report on Form 10-K, in Securities Filings: 1992 Review and Update (PLI, 1992); Form 10-K, 5 Securities Regulation (1993); Beresford, Neary, Rossel, SEC Financial Reporting: Annual Reports to Shareholders Form 10-K (1981).

180. The official designation is "Form 10-K, annual report pursuant to sections 13 or $15(\mathrm{~d})$ of the Securities and Exchange Act of 1934." 17 C.F.R. $\S 249.310$ (1982).

181. SEC Rule 14a-3(b)(9).

182. The Chronicle of Higher Education, Nov. 3, 1993, p. A21.

183. Regulation S-X governs the form and content (not the accounting standards) of financial statements. This regulation was first adopted in the 1940's. The most recent general revision occurred in 1980. Between 1937 and 1982, the SEC published 307 Accounting Series

Releases. The more important releases were codified in Codification of Fin. Rep. Policies, 6

Fed. Sec. L. Rep. (CCH), para. 72, 901 et. seq. Since 1975, the SEC has published Staff Accounting Bulletins.

184. Massachusetts Staff Draft, supra note 9, pp. 9-10, summarizing ASR 149.

185. See Loss and Seligman, Securities Regulation 1854-1916 (1990). 
186. This description of CTJ's work is based on the following CTJ publications and reports: It's Working, But...(1989); The Corporate Tax Comeback (1988); 130 Reasons Why We Need Tax Reform (1986); Money for Nothing (1986); Corporate Taxpayers \& Corporate Freeloaders (1985); and, Corporate Income Taxes in the Reagan Years (1984).

\section{See supra Part G.}

188. For a limited proposal, however, calling for the disclosure of the tax returns of millionaires, see Linder, Tax Glasnost for Millionaires: Peeking Behind the Veil of Ignorance Along the Publicity-Privacy Continuum, 18 N.Y.U. Rev. of Law and Social Change 951 (1991).

189. This same provision exists in Puerto Rico and the Virgin Islands. See 13 L.P.R.A., Sec. 3055 (1989); 33 V.I.C., Sec. 822 (1992).

190. See Part IV(F), infra.

191. Sec. 12A of Ch. 62c of the Mass. Gen. L., as inserted by Ch. 255, Acts of 1992.

192. The compromise was intended to avoid a "divisive confrontation" that "would inflict severe, long-run damage. .." Massachusetts Special Commission on Business Tax Policy, Majority Report, p. 5 (Sept. 24, 1993)(hereinafter referred to as Majority Report).

193. The Commission was charged inter alia with the responsibility of "making an investigation and study relative to the business tax policy of [Massachusetts] including, but not limited to, business tax disclosure...in the context of the goals of equity, neutrality, simplicity, tax competitiveness, confidentiality, and the public's right to know." Ch. 218 of the Act of 1992, Sec. 3. As part of that study, a report on disclosure was prepared by the staff of the Commission; see Massachusetts Staff Draft, supra note 9; see also Strauss, State Disclosure of Tax Return Information: Taxpayer Privacy vrs. The Public's Right to Know, July 1, 1993 (hereinafter referred to as Strauss).

The Staff of the Commission also issued a paper concluding that the Massachusetts tax structure was relatively neutral and equitable. See Corporate Taxation in Massachusetts: How Level is the Playing Field? This issue is independent of the disclosure issue; nonetheless, there was an attempt to confuse the two by opponents of disclosure. They argued, based on the Staff's paper, that disclosure was not needed because there were no major problems with the State's tax structure. See Boston Globe, Monday, April 5, 1993, p. 21. The Commission's Majority Report also cited that study for the proposition that "the corporate excise tax is reasonably equitable and neutral," which it then used as further evidence against disclosure. See Majority Report, supra note 192, p. 10. The actual study, however, conceded that "State and federal laws prohibit members of the public from seeing tax returns or any tax return data that could lead to identification of specific taxpayers. Therefore this study cannot address whether a particular corporation paid its 'fair share' of taxes." Massachusetts Staff Draft, supra note 9, p. 2 .

The study was strongly criticized by supporters of disclosure on numerous grounds. The study's conclusion that most of the companies that paid the minimum tax had low profits was attacked because the report was based on 1990--a recession year when many companies paying the minimum tax may have legitimately had low profits. The more interesting question is whether companies with large profits paid low state taxes, similar to the situation that existed at the federal level prior to 1986.

The study was also attacked for using a defective measure of profits. The paper was also criticized for basing one of its effective tax rate calculations on taxable income after apportionment, which ignores defects or weaknesses in the apportionment factor. Because the report worked with aggregate data based on a sample, another problem was the inability to identify outliers. By using aggregates, any skewed distribution of credits could also not be easily identified. In addition, the sample included corporations with the 250 largest tax bills, 
not corporations that were "large" using some other criteria (e.g., sales, payroll, property, book income, etc.). Finally, the sample included no insurance companies. See Memorandum from Citizens for Tax Justice to the Massachusetts Special Commission on Business Tax Policy (June 27, 1993); Memorandum from Robert Tannenwald, Research Director, to the Massachusetts Special Commission on Business Tax Policy (enclosing additional memoranda, including one from the author of the study on whether the playing field is level in Massachusetts) (June 14, 1993).

194. Sec. 82, 83 of Ch. 62cd, Mass. Gen. L., as inserted by Ch. 402 of the Acts of 1992. If the amount of any item changes, the taxpayer must file an amended report within 30 days.

195. For example, banks must disclose their net interest income; insurance companies must disclose their premiums taxable in Massachusetts.

196. Massachusetts Staff Draft, supra note 9, p. 5.

197. State Tax Notes, July 12, 1993, p. 74; Majority Report, supra note 192, p. 16. The Commission made further recommendations on bank tax reform, administrative changes, improving audits and collections, and forming a task force to study the taxation of insurance companies.

198. See Boston Globe, Sept. 30, 1993, p. 61.

199. See Massachusetts Senate Bill No. 1757.

200. Id.

201. W. Va. Stat. $\S 11-10-5 \mathrm{~s}(\mathrm{a})$.

202. Muchow, Mierke, and Lorensen, First Report on Supercredit (February 1990).

"Supercredit" is the popular name for West Virginia's business investment and job expansion tax credit.

203. This skewed distribution of the benefits also occurred in New York with respect to that State's investment and employment tax credits. See Pomp, Reforming a State Corporate Income Tax, 51 Alb. L.R. 375, 629-639 (1987).

204. Many of these findings parallel New York's experience with its investment and employment tax credits. Id.

205. It is not uncommon for the cost of tax expenditures, such as investment tax credits, to rapidly outstrip the revenue losses that were projected at the time they were first being debated. See, e.g., Pomp, supra note 203, pp. 570, 617. For a more detailed discussion of tax expenditures, see infra Section V(B).

206. Massachusetts Staff Draft, supra note 9, p. iii (Appendix).

207.Id.

208. Ark. Stat. § 26-18-303(b)(11)(A) - (P). The Massachusetts Staff Draft, supra note 9, p. 8 describes the credits covered by the Arkansas disclosure law as "small" but offers no support for this characterization.

209. Ark. Stat. § 26-18-303(b)(11)(Q)(emphasis added).

210. There is no sanction against a newspaper, however, publishing such information. 
211. If the request is for information on ten or less taxpayers, notice is mailed to the taxpayers' addresses of record. Otherwise, notice is published once in a newspaper having general circulation in the State. The person requesting the information must reimburse the Department of Finance and Administration for the cost of producing the information. Ark. Reg. 1991-7: Disclosable Tax Information.

212. See W.S. Compton v. Leathers, 92-7021, Chancery Court of Pulaski County (1992).

213. Ragland, Commissioner of Revenues of the State of Arkansas v. Yeargan, 702 S.W.2d 23 (1986).

214. An earlier proposal would have required the disclosure of all records and files of the Department of Revenue concerning all taxes except the income tax. This bill was opposed on the grounds that it would jeopardize Arkansas' exchange of information agreements with the IRS and with other states. Massachusetts Staff Draft, supra note 9, p. x.

215. The provisions in the disclosure law dealing with economic development reflected independent concerns about Japanese investment in Arkansas. The information on the events leading up to the passage of the Arkansas disclosure law is based on conversations with Arkansas journalists: Dennis Schick (8/16/93) and Carol Griffe (8/17/93).

216. 1911 Wis. Laws Ch. 658, Sec. 1087m--24(1-3).

217. 1919 Wis. Laws Ch. 638, Sec. 1087m-24(1).

218. 1923 Wis. Laws Ch. 39.

219. The Governor of Wisconsin called for repeal of the nondisclosure law shortly after World War I, when federal tax officials notified him that many Wisconsin corporations were underreporting their federal income taxes. N.Y. Report, supra note 6, n. 74. In 1943, in vetoing a bill to restore secrecy, Governor Goodland described disclosure as "an important factor in enforcing just tax obligations and in preventing tax-dodging and tax frauds." Wis. Sen. Journal 1394 (July 13, 1943). See also Groh, "Where Income Taxes are Public," The Reporter, February 19, 1952 ("Implicit in the Wisconsin system is the theory that fear of publicity discourages dishonesty and back-room deals with tax officials.")

220. A statute enacted in 1933 provided that "no person shall divulge or circulate for revenue or offer to obtain, divulge or circulate for compensation any information derived from an income tax return. .." 1933 Wis. Stat. Ch. 449, Sec. 71.20. This statute expressly excluded from its prohibition newspaper publication of income tax information and reference to such information by public speakers. Id.

221. According to Groh, supra note 219, anti-disclosure advocates included "business organizations such as Chambers of Commerce, along with a good many individuals." A Wisconsin newspaper reporter who covered the State Legislature in the late 1940s and early 1950s recalls that the Wisconsin Manufacturers' Association opposed public disclosure of income tax information and that the State's Republican Party made repeal of disclosure a political priority, claiming that it "drove business and wealthy people out of the state." Telephone interview with John Patrick Hunter, Associate Editor, Madison Capital Times, March 3, 1986.

222. The first bill to restore secrecy failed to pass. The second fared slightly better: it passed the Legislature but was vetoed by Governor Goodland. In his veto message, the Governor emphatically denounced the proposal to restore income tax secrecy:

"I have always contended and now contend that secrecy in government is a bad thing, that taxation is a public matter; that the tax returns of those who pay real 
estate and personal property taxes have no veil of secrecy drawn over them; that no honest return need fear publicity; that it is only the return made by the person or corporation that evades the law that needs the veil of secrecy. . .to shut out from public view that which may be a fraud, a cheat, or even a mistake."

Wis. Sen. Journal 1397 (July 13, 1943). Goodland cited a large volume of citizen communications urging him to veto the bill as evidence that public opinion favored disclosure. Id. at 1395.

223. 1953 Wis. Laws Ch. 303. This statute incorporated a 1951 amendment that instituted a $\$ 1$ inspection fee and that required notifying the taxpayer whose tax information was sought. 1951 Wis. Laws Ch. 714. The current statute is substantially unchanged from its 1953 form. The Massachusetts Staff Draft, supra note 9, p. 14 reports two reasons why Wisconsin changed its law from making the entire state tax return public to making only the net tax paid public. One was concern that state tax information would be abused by then-Wisconsin Senator Joseph McCarthy. The other reason was the opposition of business groups, such as chapters of the Chambers of Commerce.

224. Wis. Stat. Sec. $71.11(44)(b)(1984)$.

225. Wis. Stat. Sec. 71.11(44)(bm)(1984) prohibits disclosure to non-residents, or residents acting on behalf of non-resident individuals, firms, or corporations, "except to the extent that similar information in the state of residence of such person or firm or the state of incorporation of such foreign corporation is made available to residents of Wisconsin or Wisconsin corporations."

226. Wis. Stat. Sec. 71.11(44)(b). The requirement that an individual must state the reason for making the request is meaningless in practice. Apparently, information-seekers are not required to furnish any special reason; curiosity is sufficient. Telephone interview with Nick Baldarotta, Custodian of Records, Wisconsin Department of Revenue, March 6, 1986.

227. Wis. Stat. Sec. 71.11(44)(b). One department official reported that notifying the taxpayer of the request for information deters some persons from seeking information. "A lot of people are reluctant to let others know that they are looking for information on their tax returns." Telephone interview with Nick Baldarotta, supra note 226.

228. Conversation with Jeffrey Eagan, Executive Director, Wisconsin Action Coalition, August 18, 1993. Although the staff of the Massachusetts Special Commission on Business Tax Policy interviewed Eagan, no mention is made in the Massachusetts Staff Draft, supra note 9, that information obtained under Wisconsin's disclosure law actually led to the passage two separate times of an alternative minimum corporate income tax. That report does note that the Wisconsin Action Coalition's "widely publicized paper sparked a debate about whether Wisconsin should adopt a minimum corporate income tax." Massachusetts Staff Draft, supra note 9, p. 34, citing telephone interview with Jeff Egan [sic] of May 18, 1993.

229. See text accompanying supra note 207.

230. See supra note 199 and accompanying text.

231. This assumption is re-examined in Sec. V(A), infra.

232. See supra note 184 and accompanying text.

233. See, e.g., Legislative Analyst's Office, State of California, Analysis of the 1991-92 Tax Expenditure Budget: Overview and Detailed Compendium of Individual Tax Expenditure Programs (1991) (California's tax expenditures for bank and corporation tax programs are \$1.8 billion); New York State Department of Taxation and Finance, New York State Tax 
Expenditure Report, 1991-1992 (Mar. 1991). For a discussion of tax expenditures, see infra Sec. V(B).

234. See, e.g., Tax Reform for Fairness, Simplicity, and Economic Growth: The Treasury Department Report to the President (1984).

235. See, e.g., Pomp, supra note 203.

236. For a more detailed discussion of the state taxation of individuals and corporations, see Hellerstein and Hellerstein, State Taxation, Vols. I and II.

237. See Pomp, supra note 203, at 630-635.

238. One of the criticisms of a paper (Corporate Taxation in Massachusetts: How Level is the Playing Field?) produced by the Staff of the Massachusetts Commission, see supra note 193, was that it was forced to rely on the use of aggregates, averages, and medians, and couldn't identify any outliers. Furthermore, a meaningful effective tax rate calculation, which is needed to determine the uniformity of a state corporate income tax, is impossible to develop without some measure of book income that can be applied on a corporation-by-corporation basis, and this requires knowing the identity of each taxpayer.

239. The Massachusetts Staff Draft, supra note 9, p. 32, notes the problem of transfer pricing but concludes that "[i]n order to evaluate the degree to which the Commonwealth multicorporate taxpayers engage in such practices, investigators would need the tax returns and financial records of every affiliate of a company, including those in other states. Only auditors have, and should have, the authority to subpoena such an extensive array of documents." Apparently the report overlooks the possibility of identifying transfer pricing situations as suggested in the text.

For one recent example of a situation involving transfer pricing, see Geoffrey, Inc., v. S.C. Dept. of Revenue and Taxation, 1993 S.C. Lexis 134.

240. Without addressing any of the arguments in the text, the Chairman of the Massachusetts Commission on Business Tax Policy concluded that disclosure by corporate name "does not bring additional information to the table" compared to anonymous firm-specific disclosure Majority Report, supra note 192, p. 18.

241. See Part E, infra.

242. See supra note 197 and accompanying text.

243. Strauss notes "that the tax circumstances facing a multistate business in other states is not to be reported to the [Massachusetts] Secretary of State for subsequent public inspection, the possibilities for misunderstanding and/or misinformation appear to be significant." Strauss, supra note 193. However, Massachusetts law allows a corporation to provide any other information to the Secretary of State that it deems necessary. Even without this provision, a corporation could always use its public relations resources to avoid any misunderstanding or misinterpretation of published data.

244. See infra notes $253-261$ and accompanying text.

245. The Massachusetts legislation provides this opportunity. See supra note 196 and accompanying text.

246. Massachusetts Special Commission on Business Tax Policy described the provision in Massachusetts law that allows corporations to explain the disclosed information or provide additional information, as "connot[ing] guilt until innocence is proven." Majority Report, 
supra note 192, p. 20.

247. In comments that could describe debate over any controversial issue of the day, the Massachusetts Special Commission on Business Tax policy concluded that "public disclosure. . .may confuse rather than clarify debate about corporate tax equity. Some commentators are likely to oversimplify their analysis, claiming inequities and distortions when none in fact exists. Such charges, rather than leading to enlightened debate, could engender acrimony and hostility between public interest groups and businesses, damaging the Commonwealth's already shaky business climate." Majority Report, supra note 192, p. 20. See Part I, infra, for a further discussion of business climate issues.

248. Massachusetts Staff Draft, supra note 9, p.1.

249. L. Brandeis, Other People's Money (F. Stokes Co. 1932), p. 92.

250. Disclosure to Investors: A Reappraisal of Administrative Policies Under the '33 and '34 Securities Act (Wheat Report, 1969), p.50.

251. Kreimer, Sunlight, Secrets, and Scarlet Letters, 140 Penn. L.R. 1, 6 (1991).

252. Id.

253. Kreimer, supra note 251, p. 119. ["Dissemination of information is a large part of contemporary government practice."]

254. Seligman, The Transformation of Wall Street 561 (1982).

255. 5 U.S.C. $\S 522$

256. 15 U.S.C. $\S \S 1601-13,1631-44,1661-65,1671-77$.

257. 15 U.S.C. $1701-20$

258. P.L. No. 93-495. $\S \S 302-05,307,401-15,503,88$ Stat. 1511.

259. 12 U.S.C. $\S \S 1730 f, 1831 b, 2601-16$.

260. 15 U.S.C. $\S \S 1681-81$ t.

261. Pub. L. No. 93-406, 88 Stat. 829. These examples are cited in Stevenson, The SEC and the New Disclosure, 62 Cornell L.R. 50 (1976).

262. See Kreimer, supra note 251, p. 7.

263. Cottle, Murray, and Bloch, Graham and Dodd's Security Analysis, p. 275 (1988).

264. Id.

265. See Part G, infra.

266. Mueller, Corporate Disclosure: The Public's Right to Know, in Financial Reporting, supra note 167, p. 71.

267. Majority Report, supra note 192, p. 10. 
268. Undercutting whatever minimal benefits might flow from anonymous disclosure, the Massachusetts Senate passed a bill providing that the number identifying a corporation would change every year. See supra Sec. III(A). This approach would obviously eliminate the possibility of conducting longitudinal studies.

269. Massachusetts Staff Draft, supra note 9, p. 1.

270. For example, depending on the information covered by disclosure, it might be possible to try identify the corporations by matching such information with Form 10-K reports and annual reports.

271. See Part G, infra.

272. The remainder of this Section is based upon the author's experiences in various states as well as the issues that emerged in the Massachusetts debate.

273. Flint v. Stone Tracy Company, 220 U.S. 107 (1911). The Supreme Court has also made it clear that corporations cannot claim equality with individuals regarding rights to privacy. U.S. v. Morton Salt, 338 U.S. 632, 652 (1950).

274. See Part G, infra.

275. See Sec. V(A), infra.

276. Strauss speculates that for small, public companies, and for companies with foreign competitors disclosure will provide competitors with the private details of the company's activities. Strauss, supra note 193, p. 13. This problem is most pronounced for small, public companies and for companies with foreign creditors since "there will be an identity between their state and federal return and what they provide to the Massachusetts Secretary of State for public review. They would now have their private financial affairs subject to competitive scrutiny." Id. In the case that Strauss is worried about, where the state and federal returns are identical, it is unclear what a competitor will learn under Massachusetts law that it will not already know from examining the Form 10-K or the company's annual reports. Strauss does not discuss this possibility because his entire paper fails to mention SEC-mandated disclosed. Moreover, Strauss does not address the time delay in publishing any tax information. Finally, if foreign competitors were filing state income tax returns, they could--and should--be subject to disclosure. See Sec. V(A), infra.

277. Seligman, The SEC and the Future of Finance 203 (1985).

278. Wall St. J., Dec. 29, 1978, p. 11.

279. Foster, Externalities and Financial Reporting, 35 J. of Finance 521, 524-5 (1980). The disclosure of sales information in the SEC Form 10-K was also objected to on the grounds that it would cause single-product firms "competitive disadvantage." Id. p. 531.

280. See SEC Accounting Series Release No. 149, 1973 SEC Lexis 2313 (1973).

281. It was also alleged that disclosure would lead taxing authorities to question tax deductions or challenge the taxpayer's favorable interpretation of items.

282. See supra note 280 .

283. Even the concept of proprietary information has no fixed meaning. A former Commissioner of Taxation for New York lists without any explanation the following examples of proprietary information that a New York corporation is required to identify on its state 
franchise tax return: real estate, whether owned or leased, inventories, other tangible personal property, and business receipts. Tully, State Tax Secrecy Laws and Federal Grand Jury Subpoenas in Non-Tax Investigations, 46 Alb. L.R. 78, 84 (1981). A fortiori, much of the information on SEC Form 10-K would be "proprietary."

284. Corporations that file on a combined basis in Massachusetts will release the information covered by disclosure on a combined basis. Even if only one member of the group has extensive operations in Massachusetts, the released data will be aggregated for the combined group as a whole. It is difficult understanding how Massachusetts competitors will learn anything useful from disclosure in this situation.

285. Massachusetts Staff Draft, supra note 9, p. 18.

286. Presumably, this analyst was assuming that each store was separately incorporated in a publicly-traded corporation. But even assuming this, if a store sells a variety of products it is unclear how a competitor would be able to identify from the disclosed data which were the "hot" products, especially in fields where fads dominate and today's hot seller is tomorrow's dog.

287. During a hearing on disclosure, numerous witnesses asserted that disclosure would provide helpful information to their competitors. Not one, however, provided an example that linked the disclosed data with any conclusion that would be useful to competitors. Moreover, none of these witnesses addressed any of the points raised by the analysts in the text who felt that disclosure would reveal little valuable information. See Transcript of Public Hearing, Massachusetts Special Commission on Business Tax Policy, June 1, 1993.

288. Foster, supra note 279, at p. 531. The Line of Business Program was abandoned during the Reagan years. Rodino, Antitrust is Dead--Long Live Antitrust, 76 Geo. L.J. 507, 519 (1987).

289. Mueller, supra note 266, p. 71.

290. Id.

291. H. Rep. No. 1383, 73d Cong., 2nd Sess. 2 (1934), cited in the Wheat Report, supra note 250 , p. 50 .

292. See text accompanying supra notes 211-212.

293. Opponents of disclosure argue that it will encourage rather than deter tax avoidance because firms will fear the release of proprietary information that could help competitors. Massachusetts Staff Draft, supra note 9, p. 28. The fact that opponents of disclosure believe that it will encourage rather than deter tax avoidance because firms will fear the release of proprietary information is a damaging admission. If they assume that corporations will engage in tax avoidance to hide proprietary information why not assume that they will engage in tax avoidance for other reasons, which from their perspective, are equally compelling. In short, the argument ultimately can be turned on its head in support of the need for more disclosure rather than less.

294. Joyce, Raiding the Confessional--The Use of Income Tax Returns in Nontax Criminal Investigations, 48 Fordham L.R. 1251, 1267 (1980).

295. The Massachusetts Commissioner of Revenue testified against that State's disclosure law on the grounds it "will not help the Department of Revenue do its job." Transcript of Public Hearing, supra note 287, p. 65. Although disclosure might have some benefit in highlighting transfer price abuses and cases of tax evasion, its real benefits arise in focussing attention on 
the structure of the tax system. The benefits of disclosure would remain the same even if every tax return were filed in accordance with the law. Disclosure is concerned with the law itself and only tangentially with how corporations comply with the law. In this sense, the focus is different from the Progressives, who saw better tax enforcement as one of the benefits to be gained from their advocacy of disclosure. See supra note 90 and accompanying text.

296. Strauss argues that "[g]iven that other states do not require such public reporting and that businesses prefer to keep such matters private, it would appear that Massachusetts disadvantages itself viz a viz other states as a place in which to do business, or to locate or expand in to do business. Certainly holding constant other considerations which affect the business location decision (cost and quality of labor, transportation costs and proximity to markets, the tax costs and quality of various public services, the regulatory environment etc.), the public reporting requirements are a distinct disadvantage." Strauss, supra note 193, p. 13. He concludes that the "newly enacted public reporting requirement is part of the history and tradition in Massachusetts of general political and fiscal instability, and that the legislative process often finds it convenient to target business taxpayers. . . . Given Massachusetts' recent history of fiscal instability, it would be prudent for firms considering to move into the state or expand in the state to ascertain what else, in the areas of corporate tax disclosure or tax policy, lies in store for them." Id.

297. For a fuller discussion, see Pomp, "The Role of Tax Incentives in Attracting and Retaining Existing Business," 29 Tax Notes 521 (1985); reprinted in Multi-State Tax Commission Review (1985); Colorado Municipalities (March-April 1986); New York Economic Development Working Papers, No. 4 (Rockefeller Institute of Government, 1987); excerpted in 13 People and Taxes (September 1985).

298. The Massachusetts Staff Draft felt that the strongest argument against tax disclosure was that it would strengthen the perception that a state is hostile to business. As the staff report admitted, however, this argument is one of the most difficult to evaluate "because it is premised on a potential reaction to a unique piece of legislation that has yet to take effect." Massachusetts Staff Draft, supra note 9, p. 24. Despite this caveat, the Commission itself (as distinct from the Staff) concluded that "corporate tax disclosure will destroy jobs if corporations are required to reveal their identity in their tax reports." Majority Report, supra note 192, p. 18. This type of incautious, hyperbolic statement characterizes the Majority Report.

299. If the business involves the sale of tangible personal property, P.L. 86-272 would ensure that no income tax return would have to be filed if the only activities in the state were the solicitation of sales. If it involves the sale of services or intangible property, P.L. 86-272 would have no applicability.

300. Even state income taxes, which unlike disclosure, affect a corporation's bottom line, have very little, if any, impact on where businesses locate or expand. See Pomp, supra note 203, pp. 393-409. Accordingly, whether or not a state has a disclosure law should not effect a corporation's decision to expand or relocate in that state.

Further evidence that the disclosure issue is unlikely to affect anyone's locational decisionmaking is found in a report by Massachusetts Governor Weld's office in collaboration with the University of Massachusetts. As part of that study on the Massachusetts economy, over 2,000 business persons were interviewed. Not one raised the issue of corporate disclosure. See Choosing to Compete (Executive Office of Economic Affairs and the University of Massachusetts, 1993). Finally, a search of the Massachusetts newspapers in the Nexis computer database failed to find any article about a company's relocation to, expansion in, or relocation from Massachusetts which also mentioned the disclosure issue.

301. See Sec. V(A), infra. 
302. By way of evidence, there was substantial corporate support for the Tax Reform Act of 1986. See, e.g., supra note 3.

303. For example, the Massachusetts High Technology Council, one of the most vocal opponents of disclosure, was criticized in 1989 for actually helping to create a bad business climate. According to certain executives of high-tech companies, "The [Council's] 10-yearlong whine about excessive taxation in Massachusetts has tarred the Council with a negative one-issue image that it cannot shake.... But more pernicious than the anti-tax wailing, critics says, is the council's poor-mouthing of the state's business climate for high-tech firms." Boston Globe, July 26, 1989, p. 21. An author of a study on Route 128, Massachusetts' equivalent of Silicon Valley, described the Council as "spread[ing] the bad image of the state far and wide. If you say something is dying often enough, you hasten the problem along." Id.

304. For examples of the many situations in which the salaries of employees are public information, see Linder, supra note 188, pp. 967-68.

305. See Part B, infra.

306. For an opposite view, see Linder supra note 188 (advocating that the income tax returns of millionaires should be published).

307. If disclosure were limited to only publicly-traded corporations, the law would not cover subsidiaries of publicly-traded corporations (unless the subsidiary itself were publicly traded). Publicly-traded corporations would have the ability to avoid the law by creating a holding company to own their stock. To reach these situations, disclosure must reach corporations that are controlled directly or indirectly by publicly-traded corporations.

308. As part of his criticism of the Massachusetts statute, Strauss raises the question whether it is "appropriate or compelling to have different public disclosure standards for individuals viz a viz for profit and non-profit organization?" Strauss finds it "peculiar" that Massachusetts requires organizations to report publicly but not individuals. Strauss, supra note 193, p. 11, 12. I would have thought it was too late in the day to raise this question. For decades now, we have demanded extensive reporting by publicly-traded corporations and regulated industries with nothing comparable for individuals or partnerships. Strauss raises the possibility of requiring a high level of disclosure from both businesses and individuals. His reasoning is that "most of the population is more familiar with the mechanics of filling out individual income tax returns and the implied issues of equity and tax avoidance which accompany various deductions and sources of income. That greater knowledge and understanding should improve the enforcement value derived from such public review, since the general public would more readily understand this sort of information. ... The circumstances of many business tax returns, especially of those of multistate businesses, are inherently more complicated. It is unlikely that the general public understands Massachusetts business tax rules or those of other states as well as it understands the tax rules governing individual income taxes. . . .Also I doubt the public appreciates the considerable ambiguity in many state business income tax statutes. I would guess, overall, that public understanding of state business tax rules is in fact quite weak." Id. Strauss's arguments, could, of course, be used to justify disclosing corporate tax information as part of educating the public. Moreover, the public did not seem to have much trouble understanding the implications of the federal data released by Citizens for Tax Justice preceding the 1986 Tax Reform Act. The fact that some of the issues surrounding the corporate income tax are abstruse perhaps explains the sorry state of many state tax laws, see Pomp, supra note 203, and, if anything, supports efforts at educating the public. Finally, and quite surprisingly, Strauss does not mention or refer to the extensive reporting already required by the SEC. The Massachusetts Staff Draft acknowledges, unlike Strauss, that the appropriate balance between confidentiality and the public's right to know may be different for corporations than for individuals. Massachusetts' Staff Draft, p. 11. 
309. See Dun's Business Rankings: Public and Private Business Ranked Within Industry Category and State (1993).

310. See Part B, infra.

311. In many states, the salaries of state employees are public information. See Linder, supra note 188 , p. 967 . No distinction should be drawn between an individual who receives one form of public expenditure--a salary--from an individual who receives another form of public spending--a tax expenditure.

312. Wheat Report, supra note 250, p. 46.

313. For a perceptive discussion of the definitional issues, see McIntyre, A Solution to the Problem of Defining a Tax Expenditure, 14 U.C. Davis L.R. 79 (1980).

314. The tax expenditure concept was first developed in the United States by the late Professor Stanley S. Surrey of Harvard Law School. His work in this area reflected his experiences as assistant secretary of tax policy under Presidents Kennedy and Johnson as well as the insights gained through his other academic and scholarly pursuits. The tax expenditure concept has been described as the "major innovation in tax and public finance during the last twenty or thirty years." See Pomp, "The Mortgage Interest and Property Tax Deduction: A Tax Expenditure Analysis," 1 Canadian Tax 23 n.1 (1979). The concept of a tax expenditure was developed further by Paul McDaniel, a former professor of law at Boston College Law School and a long-time collaborator of Surrey's.

For a discussion of state tax expenditures, see Pomp, Rethinking State Tax Expenditure Budgets, 5 Public Budgeting and Financial Management 337 (1993).

315. The estimates are made on the assumption that a taxpayer's behavior would remain unchanged if the tax expenditure were eliminated. While this assumption might be unrealistic in some circumstances, a similar assumption is implicit in stating the cost of explicit spending programs. For example, a job retraining program that spends $\$ 100$ is described as "costing" $\$ 100$, even though if the program were eliminated, the amount spent on some other program, such as welfare, might increase.

316. Secretary of the Treasury, Annual Report on the State of the Finances, Fiscal Year 1968, pp. 326-340.

317. Harris, Tax Expenditure Report Titles and Sources, 5 Public Budgeting and Financial Management 521 (1993).

318. For a small sampling of the literature on tax expenditures, see Surrey, Pathways to Tax Reform: The Concept of Tax Expenditures, (1973); Surrey and McDaniel, The Tax Expenditure Concept and the Legislative Process, in Aaron and Boskin, eds., The Economics of Taxation (1980); McIntyre, A Solution to the Problem of Defining a Tax Expenditure, 14 U.C. Davis Law Review 79 (1980); Surrey and McDaniel, Tax Expenditures (1985); McDaniel, Surrey, (eds.) International Aspects of Tax Expenditures: A Comparative Study (1985). For a concise summary of the issues raised by the tax expenditure concept and an extensive citation of the literatures, see Surrey, McDaniel, Ault, and Koppelman, I Federal Income Taxation 232-254 (1986).

319. Surrey and McDaniel, The Tax Expenditure Concept, supra note 318, p. 124.

320. See Pomp, supra note 203, pp. 375, 635.

321. See Legislative Commission on the Modernization and Simplification of Tax Administration and Tax Law, The New York Investment and Employment Tax Credits, March 
11, 1985; Pomp, supra note 203 pp. 615-672.

322. Analysis of Article 9-A Business Corporation's 1986 Tax Credits, N.Y. State Dept. of Taxation and Finance (June 1991).

323. This proposal was first made in Pomp, State Tax Expenditure Budgets--And Beyond, in Gold, The Unfinished Agenda for State Tax Reform 65 (1988); see also Pomp, Rethinking

State Tax Expenditure Budgets, 5 Public Budgeting and Financial Management 337 (1993).

324. As discussed above, see supra Part A, in the case of tax expenditures there is no strong reason why disclosure should be limited to publicly-traded corporations.

325. To be sure, the amount of the triggering investment could be calculated based on the amount of the credit claimed. But there is no reason for third parties to make this calculation when the information is readily available from the taxpayer. Moreover, by requiring the taxpayer to disclose the amount of the underlying investment, a check is provided in those cases where the credit might have been miscalculated.

Under the Massachusetts law, a corporation discloses its Massachusetts taxable income and its tax. It does not disclose its credits but the difference between its taxable income multiplied by the tax rate and the tax paid is the amount of its aggregate credits. This approach is acceptable in a state such as Massachusetts, which does not have many credits. In other states it would be more useful to have the corporation disclose the amount and identity of each of its credits.

326. See generally, Pomp, Tax Reform for the 80's, 16 Conn. L.R., 925, 926-928 (1984).

327. Int. Rev. Code of 1986, Sec. 243.

328. See CCH Multistate Corporate Income Tax Guide, para. 79.

329. See, e.g., Conn. Gen. Stat. § 12-217 (1993).

330. See, e.g. Bittker and Eustice, Federal Income Taxation of Corporations and Shareholders, 5-23 (1987). The deduction can also be justified using non-normative criteria, such as making a state attractive for holding companies. Under this rationale, the provision would be properly viewed as a tax expenditure. See McIntyre, supra note 318.

331. The text assumes that the dividends constitute apportionable business income; other variations are possible. See generally, Hellerstein and Hellerstein, State Taxation, Vol. I, Ch. 9 .

332. For example, it would be difficult to imagine a state being able to enforce rules on fringe benefits that deviated widely from the federal rules.

333. See Schedule C, Form 1120 (1992).

334. The incorporation of the out-of-state subsidiary will affect the taxable income reported to A (assuming no combined report is applicable), the business apportionment factor in A, as well as the taxable income and business apportionment factors of other states with which the corporation has nexus (again assuming no combined reports are applicable in these other states). The creation of a subsidiary also lays the groundwork for using transfer pricing to shift profits from A to lower taxed states.

335. A recent study of the Connecticut corporate income tax, which exempts all dividends, calculated that one percent of corporate taxpayers reported $83.2 \%$ of the total dividends. Three firms each reported dividends of more than $\$ 100$ million. Task Force on State Tax Revenue: 
Final Report--Business Tax 62-72 (1991). Some legislators on this task force were shocked by the existence of a dividend received deduction and the accompanying data. Some of these same legislators, however, had voted for the exemption when it was introduced in 1981.

336. Some federal provisions commonly incorporated into state law include the deduction for state income taxes, see Pomp, State Corporate Income Taxes: The Illogical Deduction for Income Taxes, 42 Tax Law Rev. 419 (1987), reprinted in Multistate Tax Commission Review (Sept. 1987); the net operating loss deduction, see Int. Rev. Code of 1986, Sec. 172; the taxation of DISCS and FSCS, see Legislative Commission on the Modernization and Simplification of Tax Administration and the Tax Law, The N.Y. Treatment of DISCS and FSCS (1986); and the treatment of interest from state and local bonds.

337. See supra note 239 and accompanying text.

338. Int. Rev. Code of 1986, Sec. 6103(p)(8)(A).

339. Massachusetts Staff Draft, supra note 9, p. 16-17. Amazingly, the Commission report (as distinct from that of the Staff), fails to mention this opinion and cites the possibility of jeopardizing the exchange agreements with the IRS as one of the reasons for voting to change the current law. Majority Report, supra note 192, p. 22.

340. Transcript of Public Hearing, Massachusetts Special Commission on Business Tax Policy, June 1, 1993, p. 67.

341. See Whose Snooping Into Your Tax Returns Now?, U.S. News \& World Report, August $11,1975$.

342. Id.

343. This reading is supported by the text of the statute which refers to "his Federal return," suggesting that the draftspersons were concerned about individuals. Int. Rev. Code of 1986, Sec. 6103(p)(8)(A).

344. See supra Sec. IV (E). 